\title{
WHY DO JAPANESE WORKERS REMAIN IN THE \\ LABOR FORCE SO LONG?
}

\author{
John B. Williamson* \\ Masa Higo
}

CRR WP 2007-11

Released: May 2007

Draft Submitted: December 2006

\author{
Center for Retirement Research at Boston College \\ Hovey House \\ 140 Commonwealth Avenue \\ Chestnut Hill, MA 02467
}

Tel: 617-552-1762 Fax: 617-552-0191

http://www.bc.edu/crr

* John B. Williamson is a professor of sociology at Boston College, and Masa Higo is a Ph.D. student in the sociology department at Boston College. The research reported herein was performed pursuant to a grant from The Atlantic Philanthropies to the Center for Retirement Research at Boston College (CRR). The opinions and conclusions are solely those of the authors and should not be construed as representing the opinions or policy of The Atlantic Philanthropies, the CRR, or of Boston College. The authors want to thank Kiyoshi Adachi, Scott Bass, Masayuki Fujimura, Shari Grove, Nobuhiro Hiwatari, Elizabeth Johnson, Noriko Kameda, Kiyoko Okamura, Hisao Osada, Hiroki Satō, Takehito Shimoda, Lauren Sommer, Atsuhiro Yamada, Fusako Yanagisawa, and Shigeyoshi Yoshida for their assistance in various ways with the research reported in this paper. We also owe a great deal to many other Japanese labor force participation policy experts who gave so generously of their time in connection with this project. The authors take full responsibility for any and all errors in this paper.

(C) 2007, by John B. Williamson and Masa Higo. All rights reserved. Short sections of text, not to exceed two paragraphs, may be quoted without explicit permission provided that full credit, including () notice, is given to the source. 


\title{
About the Center for Retirement Research
}

The Center for Retirement Research at Boston College, part of a consortium that includes parallel centers at the University of Michigan and the National Bureau of Economic Research, was established in 1998 through a grant from the Social Security Administration. The Center's mission is to produce first-class research and forge a strong link between the academic community and decision makers in the public and private sectors around an issue of critical importance to the nation's future. To achieve this mission, the Center sponsors a wide variety of research projects, transmits new findings to a broad audience, trains new scholars, and broadens access to valuable data sources.

\author{
Center for Retirement Research at Boston College \\ Hovey House \\ 140 Commonwealth Avenue \\ Chestnut Hill, MA 02467 \\ phone: 617-552-1762 fax: 617-552-0191 \\ e-mail: crr@bc.edu \\ www.bc.edu/crr
}

\author{
Affiliated Institutions: \\ American Enterprise Institute \\ The Brookings Institution \\ Center for Strategic and International Studies \\ Massachusetts Institute of Technology \\ Syracuse University \\ Urban Institute
}




\begin{abstract}
As part of the search for answers to questions about what could be done to increase labor force participation rates among older workers in the United States, it makes sense to take a close look at evidence from Japan, one of the few industrial countries with a higher labor force participation rate among older workers than the United States. The gap is particularly large for male workers. The focus of this study is on six factors which help explain why Japanese workers remain in the labor force as long as they do: (1) perceived economic necessity; (2) the large fraction of workers who are self-employed; (3) a culture that puts a high value on being a productive member of the paid labor force, particularly for men; (4) the government's role in facilitating the labor force participation of older workers; (5) the long healthy life expectancy; and (6) the distinctive corporate culture's effects on marital dynamics among older generations. Based on the evidence from Japan, three policy suggestions are outlined for those seeking to increase labor force participation rates among older U.S. workers: (1) increase the financial incentive to workers who remain in the labor force; (2) increase the extent of government efforts to link older workers to prospective employers; and (3) improve public programs designed to foster efforts by older workers to become self-employed.
\end{abstract}




\section{Introduction:}

In the analysis that follows, our focus is on labor force participation among older workers $^{1}$ in Japan. We ask why it is that so many Japanese workers, particularly men, remain in the labor force well into their late 60 s and early 70 s. While our primary goal is to offer an account for current labor force participation patterns among older workers in Japan, the motivation for the analysis is the hope that there may be lessons for policy makers in the U.S. based on the Japanese experience.

During the early decades following the Second World War (the 1950s and 1960s), many nations that did not already have public old-age pension systems introduced them, and many of the nations that already had such schemes reformed them so that they would provide more generous pensions and provide those pensions to a much larger share of the population. ${ }^{2}$ During the early post-war decades, the most popular model adopted, the payas-you-go defined benefit model, was adopted in virtually all industrial nations and is the model currently in place in both Japan and the United States. This model was very well suited to the early post-war decades, an historical era of high fertility and rapid economic growth in the U.S. and in many other nations around the world. In such a demographic and economic environment it is possible to promise substantial pension benefits to a high proportion of the population, in part because most of the cost of paying for those pensions can be shifted to future generations, and in part because such schemes are relatively easy to fund so long as population growth and economic growth continue to be high.

\footnotetext{
${ }^{1}$ In this paper our focus is on labor force participation among those age 60 and over and we often use the term "older workers" when referring to workers who are age 60. We use the term "older persons" or "citizens" when referring to those (men and women combined) who are over age 60 regardless of labor force status.

${ }^{2}$ Myles (1984). See also Williamson and Pampel (1993) and Dixon (1999).
} 
But there is a downside to the pay-as-you-go defined benefit model. Pension systems based on this model become much more difficult to finance once the scheme matures, due to a much larger share of the population becoming eligible to receive pension benefits. ${ }^{3}$ In the case of the United States, Japan, and a number of other industrial nations, this fiscal burden has been exacerbated due to a set of other societal changes that have occurred as these schemes have matured. Most relevant of these changes has been the reduction in fertility and with it population aging that have contributed to the sharp increase in the ratio of retirees (receiving pensions) to covered workers (payroll tax contributors supporting the system). Another societal change contributing to the increase in this ratio has been the increase in life expectancy, more specifically the increase in the expected number of years of life after becoming eligible for public pension benefits. ${ }^{4}$ Another contributing factor has been the trend toward slower economic growth in recent decades. ${ }^{5}$

Due in large measure to the Social Security reforms of $1983,{ }^{6}$ the U.S. Social Security system is currently running a surplus; it is bringing in substantially more in worker contributions than it pays out in benefits. While there is no problem today paying the public pension benefits due, there is a projected deficit that will arise by about $2040,{ }^{7}$ and there is general agreement that the projected deficit should be addressed sooner

\footnotetext{
${ }^{3}$ Haveman, et al. (2004).

${ }^{4}$ OECD (2005a). See also Bongaarts (2004).

${ }^{5}$ World Bank (2005). See also OECD (2006a, 2006b).

${ }^{6}$ Béland (2005).

${ }^{7}$ Board of Trustees (2006).
} 
rather than later. This would make the changes (some combination of benefit cuts and payroll tax increases) less painful. ${ }^{8}$

If labor force participation rates in the U.S. were to become substantially higher for workers well into their 60s and early $70 \mathrm{~s}$, there would be a number of beneficial effects. Paying for the retirement of the baby boom generation would be less burdensome in part because the gross national product would increase. If substantially more workers were to work beyond age 70, this would help close the gap between Social Security revenues collected and pension benefits paid because there is generally very little increase in the size of the Social Security pension for those who work beyond age 70. If substantially more older U.S. workers were to remain in the labor force, this would also make it easier to finance other expenses associated with the retirement of the boomers including Medicare, Medicaid, and the anticipated burden on general government revenues when treasury bonds in the Social Security trust funds start to be redeemed to help finance Social Security pensions.

As part of the search for answers to questions about what could be done to increase labor force participation rates among older American workers, it makes sense to take a close look at recent developments in Japan, one of the few industrial nations that has substantially higher labor force participation rates among older workers than does the United States. Part I begins with a review of statistical data ${ }^{9}$ with respect to trends in

\footnotetext{
${ }^{8}$ Diamond and Orszag (2004).

${ }^{9}$ For statistical data describing labor force participation rates in the past and the present, as well as projections for the future, we rely on data provided in databases and statistical tables drawn from a variety of governmental agencies in Japan and in the United States as well as relevant international NGOs such as the International Labor Organization (ILO). In our efforts to account for the high labor force participation rates among Japanese workers, we make use of some Japanese survey research data as well as our own
} 
labor force participation rates in Japan among older workers with some comparisons to other industrial nations, but emphasizing comparisons with the United States. Part II makes extensive reference to the data presented in Part I and addresses the question: Why do Japanese workers remain in the labor force as long as they do? Part III deals with a few of the most important dilemmas and policy choices Japan is currently confronting. Finally, Part IV presents some policy suggestions for the United States based on the experience of Japan. They must, however, be taken as suggestive rather than definitive, since Japan and the United States have very different cultural and public pension policy legacies.

\section{An Overview of Japanese Older Workers' Labor Force Participation Rates Older workers in both Japan and the United States remain in the labor force long relative to other industrial nations.}

The ILO defines the "economically active population" as "all persons of either sex who furnish the supply of labor for the production of goods and services during a specified time-reference period." ${ }^{10}$ Unless specified otherwise, we will be using the ILO's definition of the economically active population when we make statements about

interviews conducted in the Tokyo area in June of 2006 with a variety of experts affiliated with public and private universities, think tanks, and government agencies. We interviewed economists, sociologists, gerontologists, and political scientists as well as researchers in various government agencies.

${ }^{10}$ In defining the economically active population, ILO explains that "production" includes all individual or collective goods or services that are supplied to units other than their producers, or intended to be so supplied, including the production of goods or services used up in the process of producing such goods or services; the production of all goods that are retained by their producers for their own final use; the production of housing services by owner-occupiers and of domestic and personal services produced by employing paid domestic staff. For a more detailed discussion of this concept, see ILO (2005a). 
differences between nations (or over time within a nation) with respect to labor force participation rates.

Japan's labor force participation rate among older workers is very high by international standards. It exceeds that of the other major industrial nations of the world. As of 2005, the labor force participation rate for older persons in Japan was 30.1 percent (Figure 1). Japan ranked third among the OECD countries if Iceland is excluded and fourth if not. Among the OECD countries, only South Korea (35.4 percent) and Mexico (34.1 percent) are reported by the ILO as having higher rates of labor force participation among older workers than Japan. Iceland is a special case not included in Figure 1, because it does not report labor force participation rates for those over age 75; but based on the data presented in Figures 2 and 3, it is reasonable to assume that Iceland also has a labor force participation rate higher than Japan for the population age 60 and over. It should be noted that Mexico is not yet classified as an industrial country; it is currently being referred to as a newly industrializing country (NIC). Iceland, while clearly an industrial nation, has a population of only 300,000. South Korea, until recently, was classified as a NIC but is now classified as an industrial country. It is the only large industrial country that has a higher labor force participation rate than Japan for those age 60 and over. From Figure 1 it is clear that while labor force participation rates for the population age 60 and over are lower in the U.S. (25.6 percent) than in Japan (30.1 percent), they are much higher in the United States than in most other industrial countries including Germany (10.5 percent), Italy (7.4 percent), and France (5.6 percent).

When we divide the population age 60 and over into four age groups (60-64, 65$69,70-74,75$ and over), we see that the high labor force participation rate for older 
Japanese workers holds up for each of these age groups. For those in the 60-64 age group (Figure 2) we see that Japan (54.7 percent) ranks fifth, behind Iceland (83.3 percent) which has by far the highest rate, followed by Sweden (60.9 percent), New Zealand (60.2 percent), and Norway (57.9 percent). Again the U.S. (51.6 percent) ranks high relative to most industrial nations, particularly the large nations like the U.K. (43.0 percent), Germany (31.6 percent), and France (17.5 percent); however, the U.S. still ranks below Japan.

Those age 65 to 69 (Figure 3) are second only to the 60 to 64 age group with respect to the potential impact on the public pension burden if a way could be found to substantially increase its labor force participation rate. This 65 to 69 age group is particularly important because it represents an age range in which many workers are physically able to work. The data suggest, though, that in most industrial nations the vast majority have elected to leave the labor force. If ways could be found to substantially increase labor force participation rates among these workers, this would greatly help in easing the burden of financing public pensions in many of these nations.

For those age 65 to 69 (Figure 3), Japan (34.8 percent) ranks fourth behind Iceland (55.6 percent), South Korea (42.6 percent), and Mexico (40.0 percent) in labor force participation. Of these, only South Korea is a large industrial nation. Again we find the U.S. (28.3 percent) at a lower labor force participation rate than Japan, but still high relative to most large industrial nations including the U.K., Germany, and France. For the 70 to 74 age group (Figure 4), Japan ranked third behind Mexico and South Korea. The rate for the U.S. is again below that for Japan, but still much higher than for most other industrial nations including the U.K., Germany, and France. It is of interest that for this 
age group the labor force participation rate in Iceland is higher than for the U.S., but lower than that for Japan. For the 75 and over age group (Figure 5), the relative rankings are much the same although, as would be expected, the labor force participation rates continue to fall. The only other industrial nation with a substantially higher labor force participation rate than Japan is South Korea. The U.S. ranks below Japan again, but substantially higher than most European countries, particularly the large countries such as the U.K., Germany, and France.

In summary, the ILO data suggest that in Japan workers remain in the labor force longer than in most large industrial nations including the United States. However, for each of the age groups considered, labor force participation rates were high in the U.S. relative to most other large industrial nations. Our discussion to this point has not taken into consideration possible gender differences. In the next section, this issue is addressed for the U.S. and Japan.

The tendency for Japanese workers to remain in the labor force longer than U.S. workers is due primarily to the very high labor force participation rates for Japanese men.

According to a recent OECD (2005c) study, during the period between 1997 and 2002 the average age retirement for men in the U.S. was 65 as opposed to 70 for Japan; for women the average in the U.S. was 63 as opposed to 66 in Japan. ${ }^{11}$ The gap in labor force participation between the U.S. and Japan for workers age 60 and over is much greater when just males are compared, as in Figure 7 (10.1 percent), than when male and

\footnotetext{
${ }^{11}$ The OECD (2005c) source uses a measure of the "average effective age of retirement." It is a pseudo cohort estimate of the average age at which workers age 40 and over leave the labor force.
} 
female workers grouped together are compared, as in Figure 6 (4.5 percent). From the data in Figure 7, we see that for the age group 60 to 64 the labor force participation rate for Japanese males is 70.3 percent in contrast to 58.0 percent for U.S. males in the same age group. For the 65 to 69 age group, the labor force participation rates fall, but again remain substantially higher for Japanese males (46.7 percent) than for U.S. males (33.6 percent). For this important age group with respect to efforts to retain older workers, nearly one half of Japanese males are still in the labor force whereas in the U.S. the level has fallen to about one third. For the 70 to 74 age group, just under 30 percent of Japanese males remain at work in contrast to slightly above 20 percent of U.S. males. For the 75 and over age group the labor force participation rate falls to 15.1 percent for Japan and to 9.4 percent for the United States. While the labor force participation rates are very low in both countries for those age 75 and over, few policy analyses are focused on ways to increase the labor force participation for this segment of the population. Of much greater importance are the very high rates for Japanese males age 60 to 64, the high rates for those age 65 to 69 , and the still very substantial rates for those age 70 to 74 .

The data on the size of the gap between Japanese and U.S. male workers presented in Figure 8 indicate that the gap is largest for workers 60 to 64, progressively decreasing for older age groups. The gap drops sharply after age 70 from 12.3 percent for those age 60 to 64 to 5.7 percent for those age 75 and over. Because labor force participation rates are higher for U.S. women between 60 and 64 than for Japanese women in the same age group, the size of the gap is substantially smaller (3.3 years) for a combined sample of men and women (Figure 8, bottom line). The trend line for male workers is not the same as the trend line for a combined sample of men and women. 


\section{In Japan a substantially larger share of older workers are self-employed than in the United States.}

It is useful to compare Japan and the U.S. with respect to the fraction of older workers in the two countries who are self-employed. While the measurement of selfemployment in these two countries may not be exactly the same, it is close enough to make comparisons useful. ${ }^{12}$ In 2001 the Cabinet Office of Japan conducted a crossnational survey of the level of self-employment among older workers (defined as age 60 and over) in various countries including the U.S. and Japan. ${ }^{13}$ In Japan, 54.6 percent of older workers were self-employed, but in the U.S. the corresponding figure was only 22.1 percent (Figure 9).

Figure 10 provides a more refined comparison dividing the older workers into two age categories. The data point to two important results. First, as we move from the younger age group (55-64) to the older age group (65 and over), we find that for both Japan and the U.S. there is an increase in the proportion who are self-employed. Second, we find that for both age groups the percent self-employed is substantially higher for Japan than for the United States.

\section{A greater fraction of older Japanese workers are part-time workers than in the U.S.}

For both Japan and the U.S., the percent of the population engaged in part-time work decreases as we move from the 60 to 64 age group to the 65 to 69 age group, reflecting the general decline in labor force participation with age. However, it is of note

\footnotetext{
${ }^{12}$ Karoly and Zissimopoulos (2004).

${ }^{13}$ The Cabinet Office, Government of Japan (2001).
} 
that in both of these age groups Japan has a higher percent of the population in part-time employment (Figure 11).

The data presented in Figure 12 indicate that in Japan a larger fraction (13.5 percent) of older workers in the labor force are permanently employed as part-time workers than is the case in the U.S. (10.4 percent). The trend is similar when we consider temporary contract workers. Again, among older workers, a larger fraction are employed in temporary work in Japan (11.2 percent) than in the U.S. (5.6 percent). The availability of more opportunities to work in the non-regular labor force may contribute to the higher overall labor force participation rate among older Japanese workers.

\section{Why Do Japanese Workers Remain in the Labor Force as Long as They Do?}

In this section the focus will be on six important factors that contribute to the Japanese pattern of high rates of labor force participation among those over age sixty. We start by discussing three factors that have received considerable attention to date, but need to be mentioned as they are very important. Briefly these three reasons are: (1) economic necessity, (2) the large fraction of Japanese workers who are self-employed, and (3) a culture that puts a high value on being a productive member of the paid labor force, particularly for men. After discussing these factors we turn to an additional three factors that are also important, even though they have received less attention than they deserve: (4) the government's role in facilitating the labor force participation of older workers, (5) the long life expectancy (as well as long healthy life expectancy), and (6) the distinctive Japanese corporate culture's effects on marital dynamics. 


\section{Economic necessity is a major reason that older Japanese (male) workers remain in the labor force so long.}

Evidence from a recent survey conducted by the Japanese Ministry of Health, Labor and Welfare makes it very clear that the vast majority of older workers in Japan remain in the labor force primarily to maintain their standard of living, that is, for economic reasons. ${ }^{14}$ In Figure 13 we see that 63.6 percent of workers age 60 and over report that they are remaining in the labor force for "economic reasons." There are several other reasons that are mentioned by at least some workers. "Social participation," "asked to work," and "to remain healthy" are all mentioned; but the number of workers who select one of these options as the primary reason is very small relative to the number who select the "economic reasons" category. The main goal for these workers is not to increase their standard of living, but rather to maintain their standard of living as close as possible to the level achieved by their late 50s. The data presented in Figure 14 suggest that those older workers who selected the "economic reasons" category in Figure 13 to explain why they are still at work are much more likely to mention the desire to maintain their former standard of living as the reason (57.4 percent) than the desire to increase their standard of living (4.9 percent). As one of our interviewees mentioned, "First and foremost many people in their early 60 s have to work ... whether they want to or not, they still need to work. Men in the 60s are still very much expected to keep working and to keep earning income to support their families.",15

\footnotetext{
14 The Ministry of Health, Labor, and Welfare (2004).

${ }^{15}$ From an interview obtained in the Tokyo area (June, 2006).
} 
This economic need to remain in the labor force is particularly important for workers between about age 60 (when many are forced to retire from their long-term career job and become eligible for an earnings related pension) and age 65 when they become eligible for a separate flat-rate pension. ${ }^{16}$ This economic need to remain at work is linked to both the policy of mandatory retirement at about age 60 for most workers and the structure of the public pension system. ${ }^{17}$ To clarify this argument, it makes sense to briefly review some of the basic features of the current Japanese pension system.

The first tier of the two-tiered Japanese public pension system is the National Pension Plan (NPP). The second tier is Employees' Pension Insurance (EPI). ${ }^{18}$ Together these two tiers make up the public pension system in Japan. ${ }^{19}$ The NPP is financed with a flat-rate contribution of approximately US\$113 per month and awarded to those who paid monthly premiums for at least 25 years. In 2005 the flat-rate benefit was approximately US $\$ 600$ per month. The eligibility age for the full NPP benefit is 65. EPI is an earnings related benefit that replaces approximately 28.5 percent of the wage for the average worker. Workers become eligible for this pension at different ages as there is some employer discretion with respect to the mandatory retirement age, but in recent years it has typically been at about age 60 (under pressure from the government this age threshold is currently in the process of being gradually increased to 65). When we consider the combined effect of receiving full benefits from both the NPP and EPI, the replacement

${ }^{16}$ Higuchi (2004). See also Bass (1996) and Clark and Ogawa (1997).

17 Seike (1993).

${ }^{18}$ Those who work in public and quasi-public sectors participate in a program called Mutual Pension Aid instead of the Employees' Pension Insurance program.

${ }^{19}$ Takayama (2001). 
rate of pre-retirement income for the average worker is closer to 60 percent. In 2005 this came to about US\$2,100 per month. ${ }^{20}$

It is worth noting that Japanese workers typically become eligible for benefits from EPI, the pension most analysts refer to as the second pillar (or second tier), at age 60 and eligible for the NPP (the first tier) at age 65. The NPP is financed on a pay-asyou-go basis with approximately one-third of the cost paid for by the national government and the other two-thirds by contributions from all adult citizens between the ages of 20 and 59. Even those who are not in the labor force must contribute. EPI is funded by a payroll tax of 13.58 percent that is split evenly between employers and employees. $^{21}$

By the early 1990s the most common mandatory retirement age in Japan increased from 55 to age 60 , the age at which workers became eligible for benefits from EPI. In response to projected population aging and the associated increase in the fiscal burden, pension benefits have been reduced, payroll tax contributions have been increased, and in 2001 the age of eligibility for NPP was increased from 60 to 65 . For several years the government has made it clear that it wants employers to increase the age of mandatory retirement from 60 to 65 . It is still at age 60 in large measure due to the high cost (and associated financial difficulties) to employers of retaining older workers. ${ }^{22}$

\footnotetext{
${ }^{20}$ Social Insurance Agency, Ministry of Health, Labor, and Welfare (2006).

${ }^{21}$ One of our interviewees asserts: "Neither the benefit structure of NPP or EPI gives older workers an incentive to retire from the labor force early. With few exceptions, such as older workers suffering from serious illnesses or disabilities, almost all older workers need to keep working first until age 60 for the benefit from EPI, and then to age 65 to become eligible for the full NPP benefit."

${ }^{22}$ Rix (1996). See also Kimura and Oka (2001) and Takayama (2002).
} 
Today in Japan most employers have mandatory retirement age rules in effect. In 2004, approximately 91.5 percent of Japanese corporations had mandatory retirement age rules. This figure includes 100 percent of corporations with more than 5,000 employees and 99.8 percent of those with between 1,000 and 4,999 employees. ${ }^{23}$ For those corporations with fixed mandatory retirement age rules on the books, 89.3 percent specify age 60 , about 6.8 percent specify age 65 , some 2.7 percent specify an age between 61 and 64, and 0.1 percent specify an age of 66 or older (Figure 15). In Japan most workers have a strong economic incentive to find a replacement job of some sort after their first retirement, at least until age 65 when they become eligible for the NPP pension.

Based on the evidence in Figure 6, we can say that for the 60 to 64 age group a higher fraction of Japanese than U.S. workers are in the labor force. We can also say that when we move to the 65 to 69 age group (and the 70 to 74 age group), the labor force participation rates fall in both Japan and the U.S., but it is of particular note that the gap between the two countries is larger for these older age groups. This is because most Japanese are unable to maintain what they consider an adequate standard of living based on the EPI benefit alone. Because they typically become eligible for this pension at age 60 and because most are required to leave their career job at age 60 , it is very common to look for another job. Some get full-time jobs, but many prefer or are only able to get parttime jobs. In Figure 11 we show that for the 65 to 69 age group more people are working part-time in Japan (10.6 percent) than in the U.S. (6.2 percent), but it is also true that in Japan more people in this age group are working full-time than in the U.S. (not shown).

\footnotetext{
${ }^{23}$ Japan Organization for Employment of Older Persons and Persons with Disabilities (2005).
} 
The argument we have made to this point is primarily useful to those seeking to account for why so many Japanese workers work to age 65 . But, as will be recalled, labor force participation rates are higher in Japan than in the U.S. (and in most other OECD countries) for workers over age 65 as well. In addition, when comparisons are made for different age groups (Figure 16), survey research data suggest that "economic reasons" remains the most common response even for those still at work after age 65. "Economic reasons" is mentioned as the most important reason for continuing to work for 57.8 percent of those ages 65 to 69. For this same age group, fewer mention "social participation" (12.2 percent) or "asked to work" (11.5 percent). Clearly these last two percentages among the age group 65 to 69 are still much lower than those associated with the for "economic reasons" response (Figure 16).

\section{The large proportion that are self-employed contributes to the high labor force participation rates found among older Japanese workers.}

The high rate of self-employment among older workers is a second factor that can be used to account for why so many older Japanese workers remain in the labor force and for why the rates are higher in Japan than in the U.S. (Figures 9 and 10). ${ }^{24}$ The argument here is that workers who are self-employed do not have to contend with corporate regulations calling for mandatory retirement at a specified age. While most Japanese corporations have mandatory retirement age rules, many Japanese workers have options (shifting to a different job within the organization, shifting to an affiliated organization, shifting to part-time employment, etc.) making it possible to work beyond the typical

\footnotetext{
${ }^{24}$ Seike and Yamada (2004).
} 
corporate mandatory retirement age. ${ }^{25}$ The evidence clearly points to an association between the level of self-employment and rates of labor force participation among older workers. When we suggest that there is a causal link between the proportion selfemployed and the labor force participation rate among older workers, we are making the assumption that for a number of reasons, including some linked to preference and some to necessity, many self-employed Japanese workers elect to remain in the labor force after age 60 .

\section{Japanese culture places a high value on being a productive member of society.}

A third factor contributing to the high rates of labor force participation among Japanese workers is the emphasis in Japanese culture on remaining productive throughout the life course. It is particularly important in this context for men to remain economically productive as long as possible. In contrast there is much more acceptance in American society for older citizens, including older men, to withdraw from the paid labor force at an age when they are still in good health and fully capable of continued work. ${ }^{26}$ It is much easier in American society for older men to construct a positive identity around leisure activities than is the case in Japan. Japanese culture puts a much higher value on work than on leisure, even among older workers. ${ }^{27}$ Such a national culture that values work over leisure is, according to one of our interviewees, "probably more prevalent in Japan than in other industrial countries, particularly those that value private life away

\footnotetext{
${ }^{25}$ Seike (2003).

${ }^{26}$ Inglehart, et al. (1998).

${ }^{27}$ Dunfee and Nagayasu (2003). See also Sengoku, et al. (1985).
} 
from collective, social regulations." ${ }^{28}$ Japan's higher labor force participation rates among older workers reflect the attitudes of older workers in Japan who are more likely to value work over leisure than are their U.S. counterparts. ${ }^{29}$

In 2001 the Cabinet Office of Japan published the results of a comparative study of the U.S. and Japan based on representative national samples of persons age 60 and over in both countries. This study attempts to get at the differences between the two nations with respect to values and attitudes about work. Some results from this study are presented in Figure 17. In both countries the modal response to a question asking about the desired age of retirement was "around 70 years old" for those respondents who were age 55 to 60 . In Japan 42.8 percent choose this age category which is very similar to the 42.3 percent figure for the U.S. respondents. Based on these data alone, we might conclude that there is little difference between Japan and the U.S., but when we look at the rest of the data, particularly for the categories just above and just below the "around 70" category, important differences emerge. For example, 16.7 percent of the U.S. sample as opposed to only 10.8 percent of the Japanese sample selected the "around age 65 " category. This points to a higher value on remaining at work in Japan than in the U.S., particularly when the data are compared for those who selected the "around age 75" in the two countries. Some 28.9 percent of Japanese respondents as opposed to only 12.9 percent of U.S. respondents selected "around age 75" as the desired age of retirement.

In 2005 the Cabinet Office of Japan published a similar cross-national opinion survey, this time of male workers over age 60 in Japan and the U.S. We will be reporting

\footnotetext{
${ }^{28}$ An interview data obtained in the Tokyo area (June, 2006).

${ }^{29}$ Okamura (1987), see also Kiyokawa and Yamane (2004), Japan Organization for Employment of Older Persons and Persons with Disabilities (2004), and Misumi and Yamori (1993).
} 
on the answers given to the question: "At what age do you think people should leave the labor force (in respondent's country)." The results are presented in Figure 18. What jumps out is the evidence that more U.S. men than Japanese men select the categories "age 65 " and each of the other categories below age 65. In contrast for the age 70 , age 75 , and age 80 categories we find the percent of the Japanese respondents who have selected the category is higher, often much higher, than the percent selecting the category among U.S. workers. If we contrast those selecting age 65 with those selecting age 70 we find the difference is much greater for the U.S. workers (45.3 percent versus 15.5 percent) than is the case for the Japanese workers (40.3 percent versus 31.3 percent). The difference between Japan and the U.S. is striking for those who select age $70(31.3$ percent in Japan versus 15.5 percent in the U.S). For age 75 we find 7.7 percent for Japan and only 2.5 percent for the U.S.; for age 80 again we find more Japanese workers selecting the category ( 2.8 percent versus 0.8 percent respectively). While there is a very clear trend in both countries for the number of respondents who think that men should leave the labor force after age 65 to fall relative to the number who select age 65 , the fall off is more gradual in Japan.

The evidence we have just reviewed is indicative of a strong work ethic in Japan. But there is additional support from other empirical studies as well. According to a recent report by Kiyokawa and Yamane, ${ }^{30} 65$ percent of the Japanese working population prefers to "keep working" even if there is no need to earn money, while those who prefer to quit working represent only about 30 percent of the population. The percentage of those who prefer "to keep working" has been in gradual decline, and that of those who

\footnotetext{
${ }^{30}$ Kiyokawa and Yamane (2004). This report makes use of a number of opinion polls based on representative national samples of Japanese workers age 20 and over.
} 
prefer "to quit working" has increased since 1983 (Figure 19). Despite these gradual trends, it is clear from Figure 19 that a majority of Japanese workers still value remaining in the labor force more than withdrawing from it. This national cultural value surrounding work still exists and is a "very precious asset that few industrial countries possess, which this country (Japan) will need to utilize in order to resolve the projected labor force shortage in the context of a rapidly aging population." 31

While these opinion polls do tell us something about the values of Japanese society, we must be careful not to overstate the link between such attitudes and eventual labor force participation in old age. Young or even middle age workers may say they want to work until they are very old, but may change their minds when they face the various physical and mental health issues that tend to emerge in late life. There are a number of such factors that will contribute to the eventual decision to retire that are generally not taken into consideration when such opinions are given.

\section{The Japanese government takes an active role in facilitating the labor force participation of older workers.}

In Japan the government has taken a number of initiatives over the years designed to foster the labor force participation of older workers. This is the fourth factor that in part accounts for the high rate of labor force participation among older workers in Japan and for why the rates are higher than in the United States. The emphasis in Japan has been different from the United States in that mandatory retirement continues to be accepted policy. Thus, much of the effort is designed not so much to protect workers from being forced to retire, but rather to provide help to workers and incentives to

${ }^{31}$ Seike and Yamada (2004). 
employers to help employees find alternative employment after being forced to retire (from their career jobs) at about age 60. As a result, a very large proportion of Japanese workers over age 60 end up in what are called "bridge jobs" in the United States. The forced retirement at age 60 does not mean that most workers leave the labor force at this age. Rather they must find another job, often one that pays substantially less, to help fill the gap between what their income was and the modest pension they receive when they retire from their long-term career job. ${ }^{32}$

Japan has enacted many laws designed to promote employment among older workers

The Japanese government has continued to take a major role over the years to promote employment opportunities for older workers. In the early 1960s the Ministry of Health, Labor, and Welfare established an advisory committee to help older people find jobs so they could remain in the labor force. ${ }^{33}$ With the passage of legislation referred to as the Employment Promotion Measures Act (Koyo Taisaku Hou) ${ }^{34}$ in 1966, it became a national priority to assist older workers who were very close to the mandatory retirement age for their employer to find a new job after this forced retirement. Based on this 1966 Act, the government went on in 1971 to enact the Law Concerning Stabilization of Employment of Older Persons (Kōreisha Tou no Koyō no Antei Tou ni Kansuru Hoōuritsu), ${ }^{35}$ (the 1971 Law, hereafter), which has been described as "the most significant public policy around which the Japanese government's endeavors for older

\footnotetext{
${ }^{32}$ Seike and Yamada (2004).

${ }^{33}$ Yashiro (1997). See also Kagiyama and Ōta (2001).

34 This policy, Law Number 132, was designed to benefit the handicapped as well as older persons.

35 This law, Law Number 68, was enacted 1971.
} 
workers' employment have revolved up until today. ${ }^{\prime 36}$ The 1971 Law outlined three goals and measures to achieve them. It was designed to secure and promote labor force participation of those age 55 and older, that is, to secure stable employment by increasing the minimum mandatory retirement age from 55 to 60 years old; to promote reemployment of those retirees who had reached retirement age; and to establish chapters of the Silver Human Resources Center. The 1971 Law has been continuously amended up to the present. The goal has been to foster measures designed to help secure the employment of older persons while taking into consideration economic and demographic changes the country has been undergoing. ${ }^{37}$

The Government of Japan enacted the Basic Law Concerning Measures for Aging Society (Kōurei Shakai Taisaku Kihon Hou) in 1997. This legislation delineated a general vision of the aging society and the basic framework for the administrative strategies to be used to maintain the overall welfare of older citizens in the midst of anticipated demographic, societal, and cultural changes. ${ }^{38}$ According to the Cabinet Office, the Basic Law was enacted "in order to develop a society in which each citizen lives with a positive purpose of life, a feeling of being integrated, and less fear of recent social changes and of changes expected in the decades ahead." 39

The 1971 Law described above was amended in $2002^{40}$ to require that employers be prepared for further increases in the mandatory retirement age. Employers were

\footnotetext{
${ }^{36}$ This quote is from an interview obtained in the Tokyo area (June, 2006), see also Seike and Yamada (2006, 2004), Rix (1996), Takahashi (1997), and Broadbent (2000).

${ }^{37}$ Seike (2006, 2005). See also OECD (2006c).

${ }^{38}$ The Cabinet Office, Government of Japan (2006).

39 The Cabinet Office, Government of Japan (2000), pp. 77-78.

${ }^{40}$ This amendment (Law Number 103) is formally referred to as the Law Amending Part of the Law Concerning Stabilization of Employment of Older Persons.
} 
required to start modifying their existing employment systems to continue employing their employees up to age 65 . This 2002 amendment was also particularly supportive of unemployed workers for whom continual labor force participation was especially urgent. In response to the 2002 amendment, during 2003, measures were introduced supporting trial employment for unemployed workers in special need, such as middle-aged household heads. The trial employment policy seeks to foster a smooth transition from temporary employment to regular employment. Under this amendment, the government also has provided, in collaboration with the private sector, seminars and counseling services to support re-employment of unemployed middle-aged workers. ${ }^{41}$ Government efforts to foster older workers' continued labor force participation has become even more diversified since the 2004 amendments to the 1971 Law. Since those amendments were enacted, the government has started providing support for employers in addition to the support for employees. The main measures introduced for supporting employers include providing consultants and financial incentives to promote employment among older workers.

The following are the subsidies for promoting older workers' continued employment that have been implemented since the 2004 amendment:

1) Subsidy to Promote Continuous Employment of Older Persons (Keizoku Koyō Teichaku Joseikin)

2) Subsidy for Short-term, Pilot Employment of Older Persons (Chūkōnensha Shikō Koyō Shōreikin)

\footnotetext{
${ }^{41}$ Japan Organization for Employment of Older Persons and Persons with Disabilities (2005).
} 
3) Subsidy to Promote Employment of Older Persons in a Particular Age Group (Tokutei Kyūshokusha Koyō Kaihatsu Joseikin)

4) Subsidy to Promote Re-Employment of Older Employees Approaching Mandatory Retirement Age (Rōudō Idō Shien Joseikin)

5) Partial Subsidy to Promote Older Persons' Business and Self-Employment Opportunities (Kōreisha Tou Kyōdōshūgyō Kikai Sōshutsu Joseikin)

The first subsidy listed above is for those employers that extend retirement ages to age 65 or older for continuous employment and those employers whose older employees exceed a specified percent. The second subsidy listed is for those employers that provide older persons seeking employment with short-term trial jobs with an eye toward eventual long-term employment. The third subsidy targets those employers that employ workers who are age 60 to 64 as permanent or long-term employees hired through Public Employment Security Offices or private employment agencies. The fourth subsidy is for those employers that assist older employees near their mandatory retirement age to prepare for becoming reemployed by other employers. Toward this end, these employers provide their older workers with the necessary information, training, and education. The fifth subsidy listed is for a group of at least three workers who are age 45 or older and plan to incorporate with a vision of creating continuous employment opportunities for other older persons. Support is also given to elderly persons who establish new businesses using their experience by subsidizing a part of the costs if they create new jobs and continuous employment for elderly workers. ${ }^{42}$

\footnotetext{
${ }^{42}$ The Cabinet Office, Government of Japan (2006).
} 
The most recent amendments of the $1971 \mathrm{Law}^{43}$ enacted in April of 2006, make it a legal requirement for employers to gradually increase the compulsory retirement age to at least age 65 by April 1, 2013. ${ }^{44}$ This last set of amendments also adds three additional obligations that employers have to meet on behalf of their current employees' smooth transition to re-employment in other workplaces, if current employers are unable to provide continuous employment until at least age 65. They are obligated: (1) to furnish a document in support of an older person's application for a new job, (2) to inform older employees who seek re-employment opportunities about the reasons for setting an age limit for entry into employment, and (3) to liberalize regulations concerning the operation of worker retirement procedures.

The fifth category of government subsidy mentioned above, Partial Subsidy to Promote Older Persons' Business and Employment Opportunities, points to yet another form of support that the Japanese government provides as part of its efforts to foster labor force participation among older workers. As encouragement for employers to utilize the government subsidy program effectively, the Cabinet Office has publicized the fact that a number of corporations have won prizes from contests linked to these programs. ${ }^{45}$ The winners are designated as model companies and the government hopes that many other companies will follow the example of these prize-winning companies. For example, Nippon Atomized Metal Powders Corporation, located in Noda City, Chiba, a

\footnotetext{
${ }^{43}$ Law Number 103.

${ }^{44}$ The Ministry of Health, Labor, and Welfare (2006a), The Partial Amendment of the Law Concerning Stabilization of Employment of Older Persons (Kōreisha Koyō Antei Hō no Kaisei ni Tsuite). This most recent amendment of the Law requires that employers gradually raise the mandatory retirement age to age 65 by April of 2013. It requires that it be increased to age 62 or over by March 2007, to age 63 or over by March, 2009, and to age 64 or over by March, 2013, and to age 65 or over by April, 2013.

${ }^{45}$ The Cabinet Office, Government of Japan (2006).
} 
neighboring prefecture of Tokyo, won a Ministry of Health, Labor, and Welfare Minister Prize for Older Persons’ Employment Development Contest for 2005. Since April 2003, Nippon Atomize has replaced an old employment policy that required workers to retire at age 60 with a new policy allowing those who so desire to keep working in the company until age 65 . Furthermore, all those who want to remain employed can modify their work schedules in a variety of different ways, such as working part-time or working every other day, depending on health status and preferred life style. Workers can keep working full-time, without their wages being reduced below the level they were earning at age 60 . The company currently employs 77 workers, of these 10 (13 percent) are age 60 and older. $^{46}$

The United States has also implemented a set of subsidy policies designed to foster employment opportunities for older workers. Of note in this context is the SelfEmployment Assistance Program; it is designed primarily to encourage and enable unemployed older workers to create their own jobs by starting their own small businesses. ${ }^{47}$ However, this subsidy program is far less available than the Japanese counterpart. While Japan's subsidy program is available nationwide, the SelfEmployment Assistance Program in the United States has been implemented in only seven states: Delaware, Maine, Maryland, New Jersey, New York, Oregon and Pennsylvania. ${ }^{48}$ Japanese government support for older workers is far more extensive than support currently found in the United States. This is another important factor to take

\footnotetext{
${ }^{46}$ Nippon Atomized Metal Powders Corporation (2006).

${ }^{47}$ Employment \& Training Administration, U.S. Department of Labor (2006).

${ }^{48}$ Blanchflower (2004).
} 
into consideration when attempting to account for the difference between the two countries with respect to labor force participation rates among older workers.

Some of the major programs for training and recruiting older workers in Japan are more effective than those in the United States.

The Japanese government's strong commitment to policies designed to foster continued labor force participation among older workers is reflected in its decision to establish the Silver Human Resource Center (SHRC, hereafter). Each chapter of this organization is fully subsidized by the national and municipal governments. Each SHRC provides community-based employment opportunities for local residents age 60 and older who seek such non-regular employment as temporary, contract, part time, or other forms of paid work. ${ }^{49}$ Since the inception of the 1971 Law, developing and expanding what eventually became the SHRC has been a major goal of the Japanese government. ${ }^{50}$ The SHRC program was formally established in 1989 and since then the number of people enrolled in the program has steadily increased (Figure 20). As the government envisioned, the level of funding for the program and the number of branches (chapters) have both steadily increased (Figure 21). Since the beginning of 2003, a program named Senior Work Programs has been organized by the Federation of SHRC chapters. In connection with this program, registered members receive free skills training, counseling

\footnotetext{
${ }^{49}$ Since the 2002 amendment of the 1971 Law, SHRC has evolved under the slogan of "active aging society" not only to provide employment opportunities but also a variety of programs fostering social participation activities for those who age 60 and over. The SHRC has evolved into a public program for the comprehensive welfare of older citizens. ${ }^{50}$ Interview data obtained in the Tokyo area (June, 2006).
} 
services for job-matching, and job interview preparation, with the cooperation of a variety of business owners' associations and public employment security institutions. ${ }^{51}$

The U.S. equivalent of Japan's SHRC is the Senior Community Service Employment Program (SCSEP, hereafter), which Congress authorized under Title V of the Older Americans Act of 1965. Established even much earlier than SHRC of Japan, SCSEP of the United States, has provided subsidized, part-time, and community service work opportunities. Those who are age 55 and over, are currently low-income, and are expected to suffer as a result of their poor employment prospects are the target population for the program. ${ }^{52}$

Despite the similar purposes underlying the two government administrative programs, the Japanese SHRC program is a far more successful public program than is the SCSEP program of the United States. The scale of the SHRC program in Japan is far greater than that of the SCSEP in the United States. As Figure 22 shows, the total annual spending in 2004 for the SHRC program in Japan was approximately $\$ 2.7$ billion, while for 2005 spending for the SCSEP program was about \$438 million. The high level of spending on the SHRC program in Japan has provided numerous employment opportunities. As a result, the income resources that the SHRC program of Japan provided for its participants in a recent year was more than six times that for SCSEP participants in the United States. Because of this funding, the total enrollment for the Japanese SHRC program grew to 772,200 by 2004 (Figure 23). In contrast, in the United States, the SCSEP had only 61,000 members in the same year, despite the U.S. being a

\footnotetext{
${ }^{51}$ National Silver Human Resource Center Corporation (2006a). See also the Cabinet Office, Government of Japan (2006).

${ }^{52}$ Senior Community Service Employment Program, U.S. Department of Labor Employment \& Training Administration (2006a).
} 
much larger country. The Japanese program has served approximately 12.7 times as many older people in need of employment than its U.S. counterpart.

The SHRC program in Japan is more explicitly focused on helping older persons remain in the labor force than is the SCSEP program in the United States. As Figure 24 indicates, for the Japanese SHRC program, men represent 66 percent of the total enrollment, but for the American SCSEP program men represent only 29 percent. The greater percentage of men than women in the Japanese SHRC program may reflect a stronger interest in facilitating continued labor force participation for older men than older women. This would be consistent with the high value in Japanese culture placed on men remaining economically productive as long as possible.

In the case of SCSEP in the United States, on the contrary, the percentage of those enrolled in the program who are older women is much greater than the percentage who are older men. Given this discrepancy, the general scope of the SCSEP program in the United States may best be understood primarily as an anti-poverty program designed to reduce poverty levels among older single people.

The Japanese SHRC program embodies a government employment strategy that has achieved greater success in facilitating older workers' continued employment and reemployment than has the SCSEP program in the United States. ${ }^{53}$ The success of the SHRC program in Japan may be due partly to its stronger emphasis on supporting continued labor force participation after age 60 .

\section{Japan has the longest and the United States has the shortest healthy life expectancy among the industrial nations.}

\footnotetext{
${ }^{53}$ Weiss, et al. (2005).
} 
Older workers in Japan are healthier than those in the United States.

As we have pointed out earlier, Japanese older workers generally prefer to remain in the labor force longer than do workers in the United States. One reason why is they are generally healthier and thus physically more able to work. This in turn is yet another factor contributing to the higher labor force participation rates among Japanese workers. When the factor of better health is combined with a less generous pension scheme than in the United States, together these factors increase the incentive for Japanese workers to remain in the labor force longer.

According to the World Health Organization (WHO, hereafter), as of 2004, Japan had a longer healthy (disability adjusted) life expectancy than any other industrial country in their study. ${ }^{54}$ As shown in Figure 25, Japan's healthy life expectancy - life expectancy free from disability - was 75.0 years old, which was by far the longest among the countries in the WHO study. Figure 25 also shows that the healthy life expectancy for the United States was only 69.3 years; that is, the U.S. ranked last among the twenty-two industrial countries included in this figure. ${ }^{55}$ Those who are age 60 in Japan can expect three more years of healthy life expectancy than can those of the same age in the United States. For the total population (including both men and women) at age 60 , healthy life expectancy is 19.6 years in Japan, but only 16.6 years in the United States (Figure 26). Both men and women in Japan achieve longer healthy life expectancies than their U.S. counterparts. In Japan healthy life expectancy for men and for women are 72.3 years and 77.7 years, respectively; for their U.S. counterparts the figures are 67.2 years and 71.3

\footnotetext{
${ }^{54}$ WHO (2005).

${ }^{55}$ National Center for Health Statistics, U.S. Department of Health and Human Services (2005).
} 
years, respectively (Figure 27). As Figure 28 shows, at age 60, on average men and women in Japan live free from disability for 17.5 years and 21.7 years, respectively, while their U.S. counterparts on average live disability free for 15.3 years and 17.9 years, respectively.

Since healthy life expectancy is a health statistic with a relatively short history, at this point in time it is not possible to compare long-term trends in the U.S. and Japan on this measure. However, data are available that let us compare long-term trends using the more conventional measure, life expectancy. Figure 29 presents trends of past and projections of future life expectancies for Japan and the United States from 1955 through 2050. During the 1950s, Americans generally outlived the Japanese; in 1955, for example, the Japanese life expectancy was 63.6, while for the U.S. it was 69.5. Up until the beginning of the 1960s, the Japanese population had reason to assume that they would not live much beyond age 60, which was often expressed in the notion of "60-year-life." Today the story is quite different. In 2005, the Japanese life expectancy was 81.5 years, while it was 77.1 years in the United States (Figure 29).

It was not until about 1970 that life expectancy in Japan started exceeding the level in the United States. Why did life expectancy for Japan start to exceed that for the United States? Do any of the factors that have been used to explain why the Japanese live as long as they do have implications for why Japanese men work as long as they do?

WHO offers an analysis of factors that may be contributing to the gap in healthy life expectancy between Japan and the United States. ${ }^{57}$ In connection with the U.S., WHO emphasizes the role of racial and ethnic heterogeneity and the associated

\footnotetext{
${ }^{56}$ MacKellar and Horlacher (2000).

${ }^{57}$ WHO (2000).
} 
population subgroups, some of which experience very poor health due in part to cultural life styles and economic structures that reduce access to adequate health services. These population subgroups include Native Americans, rural African Americans, and the largely minority inner city poor among others. ${ }^{58}$ In contrast, Japan is a much more homogeneous society with respect to culture, ethnicity, and social class. Its health care system "has ensured equitable health care delivery across different socioeconomic groups and different areas of the country." ${ }^{, 59}$ A second factor that may play a role is the difference in diet. These differences have been linked to the coronary heart disease rates that are much higher in the United States than in Japan. ${ }^{60}$

The Japanese Government has introduced a number of public policies focused on health promotion for the older population.

Since the early 1980s several laws have been enacted, each with the goal of improving the health status of the older Japanese population. Taken together, this legislation is a factor that helps account for the discrepancy in healthy life expectancy between the two countries and indirectly for the discrepancy in labor force participation rates among older workers in these same two countries.

\footnotetext{
${ }^{58}$ In addition to the WHO's analysis, see also Murray, et al. (2006) for a more systematic analysis and evaluation of the U.S. health care services.

${ }^{59}$ WHO (2006a) "Health Situation, Japan."

${ }^{60}$ In 2002, the number of deaths from coronary heart diseases in the United States was 514,450 and for Japan the number was 90,196. The numbers of deaths from CHD affect Disability Adjusted Life Years (years of healthy life expectancy) of the two counties differently; DALYS lost per 1,000 population in the United States is eight years, while in Japan it is three years. See WHO (2006b) "The Atlas of Heart Disease and Stroke."
} 
One of the earliest of these measures was the 1982 Laws Concerning Health Promotion of the Elderly (Rōjin Hoken Hou). ${ }^{61}$ Based on the administrative framework embodied in the law, the government has subsequently initiated a number of nationwide efforts seeking to promote health among older people. The Ministry of Health, Labor and Welfare has introduced many health-related programs (health education, medical checkups, rehabilitation, home care, etc.) particularly for those age 40 and over. This legislation commits the government to efforts designed to promote health for the older population; according to the Ministry of Health, Labor, and Welfare, it is imperative to promote such efforts "in order to support the future national economy.", 62

While a variety of public measures have been implemented since the early 1980s, some of the recent measures are particularly comprehensive. One example is a government-sponsored national campaign entitled Healthy Japan in the $21^{\text {st }}$ Century (Kenko Nihon 21). ${ }^{63}$ The goal of this legislation is to encourage collaboration between the public and private sectors, NGOs, educational institutions, and experts in the field of geriatric health. In connection with this campaign, the government has been attempting to develop a comprehensive environment in which the older population can access and utilize various resources for health promotion and the maintenance of good health. ${ }^{64}$ For example, various geriatric facilities, such as gymnasiums and hot springs designed specifically for older persons, have emerged due, at least in part, to government subsidies. In addition, many local municipalities have funded initiatives designed to

\footnotetext{
${ }^{61}$ This law, Law Number 80, was enacted in August 17, 1982.

${ }^{62}$ The Ministry of Health, Labor, and Welfare (2006a).

${ }^{63}$ Under this national campaign, in 2000 the government established the Japan Health Promotion and Fitness Foundation. The campaign is to continue until year 2010.

${ }^{64}$ The Cabinet Office, Government of Japan (2006).
} 
foster the value of "local health" in their communities. With public subsidies, many municipalities are also educating and recruiting younger physicians and other health care professionals into the field of geriatrics and facilitating their professional development. ${ }^{65}$

Since 2003, the government's elderly health promotion effort has focused on various preventive measures. One such measure implemented in 2003 is the Health Frontier Project (Kenkō Frontier Senryaku). The focus of this project is on lifestyle changes in an effort to reduce the prevalence of coronary heart disease among the older population. This project has been created in response to legislation called the Laws Concerning Health Promotion (Kenkōou Zoōushin Hou) ${ }^{66}$ The government has also initiated a campaign called the National Project for Promoting Healthy Diet (Shokuiku Suishin Kihon Keikau) in 2006. The main goal of this effort is to increase awareness of and knowledge among older people about how to eat a healthy diet. ${ }^{67}$ Local volunteers have helped with these educational efforts including the promotion of guidelines as to what should be included in a healthy diet. In connection with this campaign, the government has provided subsidies to food companies that make changes fostering the health promotion goals of this campaign.

As Figure 29 shows, although life expectancies in both Japan and the United States have been increasing since 1955, the increase in Japan has been more pronounced. The numerous national and local public policies in Japan focusing on health promotion among the older population, several of which we have briefly described, have contributed to the increase in life expectancy witnessed over the past few decades. Even more

\footnotetext{
65 Japan Health Promotion and Fitness Foundation (2006).

66 This law, Law Number 104, was enacted in 2002 and made effective in 2003. Unless extended, funding associated with this legislation will end in 2013.

${ }^{67}$ The Cabinet Office, Government of Japan (2006).
} 
relevant to our analysis is the case that can be made that these policies have also contributed to Japan's level of healthy (disability adjusted) life expectancy, which is currently the highest in the world. In Japan there is much more by way of government initiatives that target health promotion among the older population than in the United States. This is most likely a factor contributing to the gap between Japan and the United States with respect to both life expectancy and healthy life expectancy. While there have been extensive private sector efforts promoting healthy living among the elderly in both countries, there seems to be a more marked difference in the level of commitment to public sector efforts. ${ }^{68}$ These more extensive health promotion efforts in Japan translate into a larger fraction of older Japanese workers being physically able to remain in the labor force and presumably fewer with health and disability related incentives to leave the labor force.

\section{Gender dynamics between older male workers and their wives influence labor force participation rates in Japan.}

As discussed earlier, labor force participation rates among older Japanese workers are higher than in the United States, and they are also higher for each of the four age groups considered (Figure 6). The data presented in Figure 7 show this finding is even stronger for male workers than it is for the entire labor force (i.e., when we combine male and female workers). Given this difference, it should not surprise us that the findings for women are quite different. In Figure 30 we see that for those age 60 and over, Japanese women are no more likely to be economically active than older American women; if

\footnotetext{
${ }^{68}$ Stanford Program on International and Cross-National Education, Freeman Spogli Institute for International Studies (2004). See also WHO (2000).
} 
anything the rates are very slightly lower for Japan (21.2 percent) than for the United States (21.7 percent).

However, the story changes a bit when we divide older female workers into four age groups. As shown in Figure 31, the labor force participation rates among older Japanese female workers, at least slightly exceed their U.S. counterparts across each age group, except for the group that is age 60 to 64 (Japan, 40.1 percent versus the U.S., 45.8 percent). The major finding to take away from Figure 31 is not the small difference that we observe between Japanese and American women in labor force participation rates, rather the major finding is that the differences are generally very small. This is why the differences in labor force participation rates between Japan and the United States that we observed in Figure 6 are primarily linked to the difference in male labor force participation rates. Overall this is the case as well for each of the four age groups that we considered (Figure 7). This does leave one important difference to be accounted for. Why in Figure 31 for the 60 to 64 age group do we find a substantially higher labor force participation rate for the United States (45.8 percent) than for Japan (40.1 percent)? This difference may be due, at least in part, to age 62 being the minimum age of eligibility for Social Security in the United States.

The gender discrepancy in LFPR is greater for older workers in Japan than it is in the United States. This difference is an important factor when attempting to account for the overall difference in labor force participation rates between older U.S. and Japanese workers. This overall difference in the LFPR is as high as it is in large part because the rate is so high for Japanese men. Social and cultural factors in turn contribute to the gender discrepancy in labor force participation rates in Japan. 
Gender dynamics between Japanese older male workers and their spouses within the 'Dankai' generation may be influencing their labor force participation.

In Japan there has been much speculation, but relatively little empirical research on the impact that the gender dynamics of Japanese marriages is having on labor force participation rates among older workers. This line of argument frequently came up in our interviews conducted in Tokyo. Many Japanese researchers are, as one of our interviewees put it, "interested in clarifying what social and cultural factors in Japan generate motives or reasons for older men in Japan to remain in the labor force...there may be more than an economic incentive or reward for them to keep working after age 60. We [Japanese sociologists and gerontologists] always try to articulate some daily life conditions surrounding today's older men that give them incentives not to retire and stay at home...."69

An important source of the large gender gap in labor force participation rates in Japan between men and women in all age groups and particularly older workers is the very widely shared social norm supporting a division of labor between the genders, a division of labor similar to that which characterized the first few decades after the Second World War in the United States and most other industrial nations as well. Labor was divided into men's and women's spheres with the former almost always involving wage labor in the formal labor market and the latter typically involving unpaid labor in the domestic household. ${ }^{70}$ This set of norms was strongly reinforced during the period of very rapid economic development in Japan from the late 1960s through the 1980s and

\footnotetext{
${ }^{69}$ Interview data obtained in the Tokyo area (June, 2006).

${ }^{70}$ Yamato (2006). See also Aoi (2004).
} 
seems to have been stronger in Japan than in the United States. Today in Japan it is particularly strong among those who are currently age 60 and over. ${ }^{71}$ According to the interviewee mentioned above, while Japan has long since achieved the status of an industrial nation, its norms with respect to the gender division of labor (which are in the process of changing for younger generations ${ }^{72}$ ) are still very strong among those age 60 and over, the age group of particular interest to our analysis.

Given Japan's rapid population aging in recent decades and current projections with respect to future population aging and with respect to the decline in the of size of the labor force, policy analysts have become very interested in a particular "generation" born between 1946 and 1950: the Dankai ${ }^{73}$ generation. Because this generation is larger than any other generation in the whole post-war history in Japan, ${ }^{74}$ the Dankai generation is often described as the Japanese equivalent to the baby boomers in the United States. However, it does differ in some fundamental respects. For example, it is much shorter, lasting only five years as opposed to 18 years for the United States. ${ }^{75}$ For this reason it makes up a much smaller fraction of the total population. In Japan the upcoming retirement of the Dankai generation is projected to affect public old-age social security

\footnotetext{
${ }^{71}$ Harris and Long (1999), see also Long and Harris (2000) and Takahashi (2001).

${ }^{72}$ The Cabinet Office, Government of Japan (2006).

${ }^{73}$ The term, 'Dankai' literally refers to a "coherent, solid generational group." This particular generation was originally described, somewhat stereotypically, in this way by the mass media because of their distinctive social and cultural values, such as strong political partisanship, materialism, and support for Western life styles, which are considered to be commonly embraced among this generation. See Hagiwara (1972) for more in-detailed definition of the Dankai generation.

${ }^{74}$ According to the Ministry of Health, Labor, and Welfare (2002), the Dankai generation numbers about 8 million people. In contrast in the U.S. the term "baby boom generation" refers to the 78 million Americans born between 1946 and 1964.

${ }^{75}$ In this sense, this particular group needs to be perceived as a cohort, rather than a generation. In most cases, however, the Dankai group is translated into English as the Dankai generation.
} 
policies and the national economy more generally. ${ }^{76}$ Perhaps, more relevant to our analysis of why Japanese men remain in the labor force so long is that the Dankai generation is considered by many to be the last generation that represents the traditional attitudes and values that favor work over leisure that are so strongly held by those

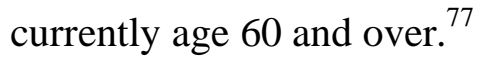

Having experienced the nation's dramatic economic development from the mid1970s through the early 1990s, often as employees of large corporations, male members of the Dankai generation have developed corporate lifestyles that in turn have shaped family and marital lifestyles. The men have spent long hours at the office and long hours with co-workers socializing into the evening while wives have developed lifestyles that involve their children, female friends, and female relatives with very little involvement of their husbands except as breadwinners. ${ }^{78}$ The Dankai husbands have spent most of their lifetime as corporate workers and loyal company men. In turn, the corporation has provided a community, a source of social networking, an identity, and a purpose for life. ${ }^{79}$ One of our interviewees puts it this way:

"For many of them, especially the more successful employees, retirement represents one of the most catastrophic events in their lives. It is the time at which all the social resources that they have enjoyed for so many years and that have

\footnotetext{
${ }^{76}$ Concerns about the potential effects of the retirement of the Dankai generation are often phrased as the "Year 2007 Problem." For, in 2007, the oldest among the Dankai generation will reach age 60. Most companies will not allow workers to keep working beyond age 60 (in their career jobs) because of mandatory retirement rules.

77 Yamagami et al. (2003), see also Okamura (2001)

${ }^{78}$ Yamamoto and Komatani (2003)

${ }^{79}$ Amano (2001). See also Sasatani (2005) and Ōishi (2000)
} 
been central to their social well-being before are suddenly taken away. At this point they have to start over and develop new social networks and a new purpose of life. This process can be very painful especially in old age. Fully aware of the sudden changes in their lives that will occur with their forced retirement (from their career job), they become more and more anxious and even fearful as they come closer to their retirement age." 80

Due to problems associated with adjusting to a post-retirement lifestyle, many Dankai men find it hard to develop new leisure interests or new friendship networks in retirement. ${ }^{81}$ Often they turn to their wives to meet most of their needs for social interaction. ${ }^{82}$ The Dankai wives, in contrast, have over the years developed a number of leisure interests that easily carry over into the retirement years and they generally have well-developed friendship networks that again are easy to carry over into retirement. ${ }^{83}$ Many of these wives have been either housewives or part-time employees for many years and this has freed up time during the pre-retirement years for such activities. However, for the Dankai husbands, retirement is often not only a problem for the retiring husband, but also for the husband's wife. It becomes a problem for the wife when a husband who has few friends outside of the work environment and little by way of leisure interests comes to expect his wife to spend most of her time with him, a demand on her time that gets in the way of her long-established social networking patterns, time she is used to

\footnotetext{
${ }^{80}$ Interview data obtained in the Tokyo area (June, 2006).

${ }^{81}$ In much of the literature there is reference to the sorrow and anxiety that Dankai husbands often experience as a negative side effort of retirement policies linked to postwar Japan's dramatic economic development (Miura 2005).

${ }^{82}$ Sodekawa, et al (2005). See also Maeda (2006).

${ }^{83}$ Research Institute for Hi-Life (2003).
} 
spending with her friends or in her leisure activities that are of no interest to her husband. ${ }^{84}$

There is a great deal of evidence to support this view of what seems to be going on. According to one opinion survey on the Dankai generation's visions of their lifestyle after retirement, ${ }^{85}$ the wives are even more likely than their husbands to feel stressed about their husbands' upcoming retirements. As shown in Figure 32, on the one hand, 35 percent of the wives feel "relatively uneasy" about their husbands' upcoming retirement and another 3.8 percent feel "very uneasy" about it. On the other hand, only 14.5 percent of the husbands feel "relatively uneasy" and virtually none of them report feeling "very uneasy" about the impending retirement. As we show in Figure 33, this survey also suggests that husbands are likely to prefer being socially "laid-back" (61.5 percent) to remaining socially "active" (38.5 percent). In contrast, wives are more likely to prefer that their husbands remain socially "active" (53.4 percent) as opposed to being socially "laid-back" (46.6 percent). Similarly, as indicated in Figure 34, as their ideal future lifestyle, husbands are likely to prefer "enjoying solitude" (61.1 percent) to remaining "socially outgoing" (38.9 percent). Wives are, however, more likely to prefer that their husbands remain "socially outgoing" (60.3 percent) to their husbands "enjoying solitude" (39.7 percent).

\footnotetext{
${ }^{84}$ Yuki (2003). See also Maeda (2005) and Shishido (2004). In much of the English language literature and mass media, this phenomenon, unique to Japanese marital dynamics, has recently been referred to as "Retired Husband Syndrome" (Faiola 2005).The symptoms of this syndrome include "irritability, ulcers, rashes, and the recurring urge to toss one's husband out the window" and this syndrome is today "one of the leading causes of divorce among older couples in Japan" (ABC News 2006). ${ }^{85}$ Hakuhōdō Elder Business Promotion Office conducted "Hope Report XV Dankai Generation Husbands Research in 2004" with the sample of 234 pairs of husbands and wives in Dankai Generation residing in Tokyo, Osaka, Kyoto, and Kobe prefectures. The research duration was from the beginning to the end of August in 2004.
} 
The Cabinet Office conducted another opinion survey concerning the most desirable way to relate to one's spouse after retirement for the Dankai generation. ${ }^{86}$ As shown in Figure 35, a majority of both husbands and wives choose "spending time with spouse while respecting his/her privacy" as the ideal way to spend time after retirement. However, the percentage of wives who choose "spending as little time as possible with spouse to respect spouse's privacy" is more than three times as high as that of those husbands (18.2 percent versus 5.0 percent). Furthermore, the percentage of husbands who chose "spending as much time as possible only with spouse" is nearly five times as high as that for wives (30.0 percent versus 6.1 percent). The Cabinet Office also conducted an opinion survey about the types of leisure that Dankai husbands and wives say they want to spend their leisure time on after age 60. As shown in Figure 36, husbands tend to prefer leisure activities that require fewer social skills and less socializing such as “driving" and "watching TV and reading newspaper." In contrast wives tend to prefer “community volunteer activities," and "social activities with friends." 87

Furthermore, husbands and wives among the Dankai generation have different opinions about the ideal way to receive care in old age. As Figure 37 indicates, the percentage of husbands who choose their wife as the ideal person to be providing this care is more than ten times as high as the percentage of wives who choose their husbands as the ideal person (65.0 percent versus 6.1 percent). The percentage of wives who choose moving into an institution, such as a long-term care facility is more than eight times as high as that of husbands (42.4 percent versus 5.0 percent).

\footnotetext{
${ }^{86}$ The Cabinet Office, Government of Japan (2001).

${ }^{87}$ Miura (2005)
} 
Our interpretation of the evidence with respect to the Dankai generation, based on the survey research evidence and our interviews, is that Japanese wives tend to prefer that their husbands remain in the labor force as long as is feasible. This also makes it easier for wives to finance their pre-retirement lifestyles. Given the common pattern for Japanese men to focus their social life around after-work activities with co-workers, remaining in the labor force is for many men the easiest way to retain a social life. ${ }^{88}$

In addition to the purely economic incentive to remain in the labor force that we have discussed earlier, older male workers in Japan and particularly the Dankai husbands, have a number of other reasons, especially those related to the distinctively Japanese marital dynamics, to delay withdrawal from the labor force as long as possible. While some of the same factors are also at work for many male workers in the United States, ${ }^{89}$ the American pattern of late-life marital dynamics is generally not as rigid as that in Japan. American men generally have more leisure interests to occupy their time during retirement than do Japanese men. As a result they tend to be less socially isolated and less dependent on their wives for social interaction than their Japanese counterparts. ${ }^{90}$ While many retired male workers in the U.S. face social isolation and increased dependence on their wives for social interaction, the pattern is more pronounced in Japan.

\section{Choices and Dilemmas Facing Government Policy Makers in Japan}

In the discussion that follows, our focus is on some important aging issues that Japanese government officials and policy makers are likely to be dealing with in the

\footnotetext{
${ }^{88}$ Sato (2005), see also Okamura (2001)

${ }^{89}$ Ono and Lee (2006), see also Moen, et al. (2001).

${ }^{90}$ Mouer and Kawanishi (2005).
} 
decades ahead. Despite very high labor force participation rates for older workers, Japan is projected to have a major labor shortage in the decades ahead. ${ }^{91}$ Policy makers will have to balance the needs of elders with the needs of the Japanese economy as a whole. We will focus on three such issues. While our focus will be on Japan, the discussion will also have implications for policy makers in the United States as well.

The first issue is the extent of government efforts to facilitate and foster continued labor force participation among older Japanese workers. We have already discussed a number of the programs and policies in place that are designed to promote the continued employment of older workers. We now want to ask whether the primary goal of such efforts is to increase the aggregate hours of labor supplied by older workers or to increase the proportion of the older population in the labor force, whether part or full time. If the answer is the former, these programs can be viewed as efforts to increase the current and future supply of labor. If the answer is the latter, then the primary goal might be to foster the social integration of the older population with the rest of society. According to a recent whitepaper prepared by the Ministry of Health, Labor, and Welfare, due to the rapid population aging projected to take place between now and 2050, approximately one person in three in Japan will be over age 60 in 2050. To maintain socioeconomic vitality under these circumstances, this report asserts that it will be necessary for as many of the elderly as possible to take an active part in the economy. To realize this goal, the report suggests a need to create a society in which a high proportion of motivated and able citizens continue to work regardless of their age. ${ }^{92}$

\footnotetext{
${ }^{91}$ OECD (2005b).

${ }^{92}$ Ministry of Health, Labor, and Welfare (2006b).
} 
Arguably, the Ministry of Health, Labor, and Welfare is primarily concerned with the trend in the national economy and the projected labor force shortage. Thus, according to the above mentioned report, it is imperative that Japan be a "society in which motivated and able persons can continue to work regardless of their age." Or, as one of our interviewees puts it, "First and foremost, the government is seriously concerned about the projected decline in the size of the national labor force in the relatively near future. To the government, older people who are capable of working and willing to do so are going to be a very valuable asset in dealing with this problem." 93 There is a strong need to meet the future labor supply not only to mitigate the projected financial burden of the existing public pension scheme, but also to maintain the future national economy in a more competitive, global market. ${ }^{94}$

But not all of the evidence points in this direction. There are those who argue that government efforts to foster labor force participation among older workers are driven by a different agenda. Some argue that a major consideration, if not the most important consideration, is the desire to assure that older (male) workers be protected from the social isolation often associated with lack of employment. As discussed previously, among those in the Dankai generation a very high value is placed on remaining economically productive well into old age. From this perspective these government programs can be viewed as a response to a widely held value that opportunities should be retained for older (male) workers to remain in the paid labor force as long as possible. ${ }^{95}$

"As the most powerful guardian in this country, the government attempts to take care of all aspects of the citizens' lives. It has always been imperative for the

\footnotetext{
${ }^{93}$ From an interview obtained in the Tokyo area (June, 2006).

${ }^{94}$ Seike and Yamada (2004). See also Watanabe (2004).

${ }^{95}$ Sodekawa et al (2005). See also Fujimura (2004).
} 
government to help provide all citizens with what is called Ikigai - defined as a purpose for life or something to live for. This is a very basic value that under girds government efforts to integrate all citizens and to help the whole country to function in a harmonious manner. Many older people want to maintain their Ikigai by remaining economically productive in society....assisting older people in remaining in the labor force is ... the best way for the government to help integrate older people who would might otherwise lose Ikigai ...." 96

Echoing this perspective, another interviewee used the expression, "from the cradle to the grave," to describe the government's role in relation to the citizens. The interviewee noted, "Historically, the government is assumed to be involved in citizens' lives from the very beginning to the very end of their lives. The government looks to the general population for general visions of what citizens want and then takes as its task to develop the means and strategies for the citizens to realize those goals. ${ }^{97}$ Citizens from all sectors of society follow the government guidance just as students in a classroom follow their teacher's instruction...." 98 "Unlike such a highly market-oriented country as the United States," this same interviewee argued, "Japan's political structure is highly government-centered, and its culture is very homogeneous. It is very important to a society like this to avoid the social chaos that would result were the nation's elderly to become socially isolated from the rest of society."

Arguably, older workers are one of the most vulnerable population subgroups, particularly in the face of a rapidly changing and very competitive labor market. From this perspective, it is reasonable to think that a major motive underlying the government's

\footnotetext{
${ }^{96}$ From an interview obtained in the Tokyo area (June, 2006).

${ }^{97}$ Nariai (1999).

${ }^{98}$ Interview data obtained in the Tokyo area (June, 2006).
} 
efforts to promote the labor force participation of older (particularly male) workers is to foster their social integration and social welfare, rather than just to increase the labor supply of the older workers. The two perspectives just presented (emphasizing the needs of the overall economy versus the needs of older workers) may seem to contradict one another. However, our interpretation is that for the Japanese government and particularly for the Ministry of Health, Labor, and Welfare, these two goals are both viewed as very important. Many Japanese older (male) workers are unwilling to leave the labor force because retirement often results in the termination of many social welfare benefits as well. "The government and policymakers have been coming up with a variety of legislative measures designed to foster their continual labor force participation so as to meet both needs." 99

To this point our discussion has focused on male labor force participation. We now turn to the second major issue to be discussed in this section, the policy initiatives necessary to foster higher labor force participation rates for older women and for young adults of both genders. It is clear that there would be potential benefits to the economy were labor force participation rates to increase for women at all ages, including older women. But Japan is also facing a problem of very low fertility rates. ${ }^{100}$ Policies designed to increase labor force participation rates among women run the risk of even further suppressing Japan's already very low fertility rate. If more women are in the labor force, the demands associated with many jobs will make childrearing a greater burden. Policies designed to increase labor force participation for older women may have the unintended effects of reducing participation rates among men and also of reducing participation rates

\footnotetext{
${ }^{99}$ Interview data obtained in the Tokyo area (June, 2006)

${ }^{100}$ Japan Aging Research Center (2004).
} 
for younger women. If a larger proportion of older women were to remain in the labor force, this would reduce the supply of an important source of childcare support for their daughters, many of whom are also mothers who want to remain in the labor force.

Stated another way, Japanese policymakers face some difficult tradeoffs if they try to solve the projected labor force shortage by promoting efforts to draw more women into the labor force or to retain those who are already in the labor force. Such policies could reduce the future labor supply of both genders. A number of European countries face serious population aging problems, but do have fertility rates that are substantially higher than those in Japan. Policymakers in Japan may well benefit from a close analysis of the many forms of government support for young mothers in such countries as France ${ }^{101}$ and Norway. ${ }^{102}$ To the extent that Japan continues to promote efforts to keep older males in the labor force, there is the risk that such efforts will reduce the number of jobs available to younger workers. This would not only lower the labor supply of younger workers, it would also run the risk of an increasing fraction of these workers developing what Japanese employers consider bad work habits, a charge made about many young adults who move from one low-paying temporary and part-time job to another for several years without seeking stable, continuous employment, thus making it difficult for them ever to get good jobs. ${ }^{103}$ Ways need to be found to promote labor force participation among older workers, both men and women, ways that do not have a substantial impact on labor force participation rates among younger workers. Many of those we interviewed argued that efforts to promote labor force participation among older workers are unlikely

\footnotetext{
${ }^{101}$ The Economist (2003).

102 BBC News (2006).

${ }^{103}$ The term "freeters" is used to describe these young workers (Honda, 2005). See also Kosugi (2004a, 2004b) and Brinton (2000).
} 
to adversely impact the job prospects for the young adults because they are not competing for the same types of jobs. A second argument is that the future job shortage is projected to be so severe that there is going to be a very high demand for workers, even for the very young workers currently finding it hard to find suitable employment.

Mainly because of very low fertility rates, Japanese policy makers are currently much more concerned about future labor shortages than high unemployment rates. As Figure 38 indicates, labor force participation rates among Japanese workers (age 15 and older) are projected to steadily decline through 2020 . This decline also includes two groups of older workers, those age 60 to 64 as well as those age 65 and over. The decline is projected to be stronger for male (Figure 39) than female (Figure 40) workers. The projected trend is quite flat for older women. Given these trends, particularly for men, it is reasonable to expect labor shortages in the years ahead. Such trends are likely to motivate the government to look for ways to increase labor force participation, particularly among women, as many older Japanese women are in good health and have a long healthy life expectancy.

As Figure 29 shows, healthy life expectancy for Japanese women is 77.7 years, which is substantially longer than for their Japanese male counterparts (72.3 years), U.S. women (71.3 years), and U.S. men (67.2 years). Given their longer years free of disability and their currently low labor force participation rates, it would seem that Japanese women constitute a potentially substantial source for increasing the labor supply among older workers.

The third of the three issues to be considered in this section is what is referred to as "workplace flexibility" in the United States. This too is an important policy issue for 
Japan. It raises issues that will have important implications for future labor force participation rate trends in Japan. In the post-industrial era, an increasing number of countries have seen a fraction of older workers come to be employed under more flexible conditions with respect to the terms of the employment contract, the number of hours worked, the number of days worked, the flexibility of the job with respect to which days and which hours are worked, and the like. ${ }^{104}$ As a term referring to this set of emerging employment patterns, the concept and practice of workplace flexibility raises a number of questions about how much such workplace flexibility currently exists in Japan. ${ }^{105}$

As far as employment status and forms of labor force participation among older workers are concerned, Japan seems to have more flexibility than the United States. Figures 9 and 10 indicate that the fraction of older workers who are self-employed is substantially higher in Japan than in the United States. In this respect a case can be made that older Japanese workers have more workplace flexibility than do older workers in the United States. However, in the United States, very few workers are subject to mandatory retirement rules that confront almost all Japanese workers at about age 60. In this sense many American workers have more flexibility in deciding when to retire from their career jobs.

In a recent whitepaper, the Cabinet Office, Government of Japan acknowledges an increasing demand from workers both to be able to work well into old age if they so elect and also to be given more control over when and how much they work, so as to assure a better balance between work, family life, and community participation. The

\footnotetext{
${ }^{104}$ See Vallas (1999) and Curl and Hokenstad (2006) for more analysis of the concept of "workplace flexibility."

${ }^{105}$ Everingham (2002).
} 
whitepaper asserts that Japanese workers should have a greater variety of options and more workplace flexibility so as to provide a better fit with their lifestyle preferences. ${ }^{106}$

On a public policy level, the Law Promoting Shorter Work Hours (Jitan Sokushin Hou $)^{107}$ first went into effect in 1988 , and a revision of this original law called the Law Concerning Improvement of Work Hours and Other Conditions (Rōdō Jikan Tou Setei Kaizen Hou $)^{108}$ was implemented in 2006. The 2006 revision of the law encourages employers to reduce the annual number of work hours as well as to develop and implement various measures designed to improve overall work conditions for employees. The goal is to promote more flexible employment options so as to be suitable for a wide variety of lifestyles and to foster both good physical and mental health among workers of all ages. For older workers, the Short-hour Regular Employee System for the Elderly (Kōrei Tanjikan Seishain Seido) has been in place since 2004. With government subsidies financial incentives are provided to employers that adopt this system for their older employees. $^{109}$

According to the Ministry of Health, Labor, and Welfare, ${ }^{110}$ the various programs and policies that we have described have been developed and implemented so as to increase workplace flexibility for Japanese workers. However, several of our interviewees argued that, as of today, the forms of workplace flexibility that the government has been promoting tend to favor employers. As policies promoting

\footnotetext{
106 The Cabinet Office, Government of Japan (2006).

${ }^{107}$ The full, official name of this law is Roudou Jikan no Tanshuku no Sokushin ni Kansuru Rinji Sochihou (Law Number 90).

${ }^{108}$ The full, official name of this revised law is Roudou Jikan Tou no Settei no Kaizen ni Kansuru Tokubetsu Sochihou.

${ }^{109}$ Japan Institute for Labor Policy and Training (2005).

${ }^{110}$ Ministry of Health, Labor, and Welfare (2006b).
} 
workplace flexibility are relatively new to Japan, it may take another decade or so to get a clear idea how beneficial these policies are to workers themselves. Until this is done, it makes sense for U.S. policy makers to be cautious about drawing lessons for the United States based on Japanese experience with work place flexibility. ${ }^{111}$

\section{Suggestions for the United States Based on the Evidence from Japan Suggestion 1: If the goal is to increase labor force participation among older workers in the U.S., increase the financial incentive for older workers to remain in the labor force.}

The primary reason that American policy makers have an interest in increasing labor force participation rates among older U.S. workers is the expectation that it would help reduce the burden on the government associated with financing the health insurance and Social Security pension benefits for the retirement of the baby boom generation. The evidence that we have presented concerning Japan suggests that one way to increase labor force participation rates among older workers in the U.S. may be to increase the economic incentives for remaining in the labor force longer than is the pattern today. This can include penalties for retiring early or increased benefits for remaining in the labor force longer.

As noted earlier in this paper, the labor force participation rate for Japanese workers age 60 and over is one the highest for the industrial nations (Figure 1). When workers are asked why they are still in the labor force, most answer "for economic reasons" (Figure 13), and when asked to get more specific about these economic reasons the goal seems to be to maintain their standard of living (Figure 14). The rationale of

${ }^{111}$ Based on interview data obtained in the Tokyo area (June, 2006). 
economic need seems to be an important factor when the goal is to account for why so many of those age 60 to 64 remain in the labor force, as there are severe penalties associated with taking the National Pension Plan benefit before age 65. In addition, most Japanese workers do not feel that they can get by solely on Employees' Pension Insurance for the years between age 60 and 65 .

How does this translate into policy suggestions for the United States? One interpretation is that it might be possible to increase labor force participation rates for older American workers through some combination of increased benefits for remaining in the labor force longer or greater penalties for leaving the labor force while still in one's early 60s. The current policy of increasing the normal retirement age from 65 to 67 with a corresponding reduction in the size of the pension benefit for those who elect to take the earliest Social Security pension benefit at age 62 is consistent with this logic. Efforts could be made to pursue this direction by increasing the normal age of retirement, to say 68 or 70, and there could be a corresponding further cut in the benefit for those who continue to take the benefit prior to the so called "normal age of retirement." While this might well help increase overall labor force participation rates for workers between the ages of 60 and 70, this benefit would be accompanied by some adverse personal consequences. For some workers the cost would be relatively modest, but for many others there would be a very high cost associated with such a policy change. In this context we have in mind those workers, often low-wage workers, who find it very hard, stressful, or physically impossible to work at age 69 or 70 . While disability benefits would be available for some, it is not clear that the disability program would be able to fully meet the demands associated with this set of policy changes. 
It might make sense to increase the economic incentives to remain in the labor force longer. The economic incentives argument works well to account for why Japanese workers are more likely to be in the labor force between the ages of 60 and 64 . But it does not account for why Japanese workers are more likely to remain in the labor force between the ages of 65 and 69 or between 70 and 74 (Figure 6). It turns out that the net income replacement rate of the Japanese pension system is approximately 59 percent whereas the replacement rate for Social Security in the United States is closer to 51 percent. ${ }^{112}$ After age 65 in Japan the major pension based economic incentive is no longer in play, but the evidence is very clear that labor force participation rates continue to be higher for Japanese workers for the older age groups, particularly for men (Figure 7).

However, there is another economic line of argument that may be important. In Japanese culture there seems to be a greater expectation than in the United States that grandparents are responsible for the economic well-being of their children and grandchildren so long as it is possible for them to do so. There are stronger expectations than in the U.S. that grandparents help their children and grandchildren pay for education and housing loans. ${ }^{113}$ When this set of expectations is factored in, the "perceived replacement rate" may turn out to be lower in Japan than in the United States. The older (male) Japanese worker is culturally expected to be responsible for a broader range of family-related economic needs.

\footnotetext{
${ }^{112}$ OECD (2006c).

${ }^{113}$ Elmelech (2005).
} 
Suggestion 2: It should be possible to increase labor force participation rates among older workers in the U.S. by increasing the extent of government intervention in the economy and fostering mechanisms to link older workers to prospective employers.

Our second suggestion is for American policy analysts to take a close look at some of the recent and very successful Japanese employment programs designed to meet the needs of older workers. These programs have done a good job of finding ways to link older workers to prospective employers. The efforts have undoubtedly contributed to the high labor force participation rates for older Japanese workers.

In Japan, arguably, the most effective government program designed to link older workers to prospective employers is the Silver Human Resource Center (SHRC) program. As a full-fledged, nationwide senior employment program, SHRC has clearly played a major role in facilitating employment among older workers. Not only does SHRC facilitate efforts to find job openings that are suitable for older workers, it also plays an important role in preparing workers for these jobs by providing counseling and job training through its Senior Work Programs.

Due to the lack of comparable data, it is difficult to make precise comparisons between the SHRC program in Japan and what is arguably the closest analog in the United States, the Senior Community Service Employment Program (SCSEP). The data presented in Figures 22 and 23 make it clear that the Japanese government is putting more resources into its program and as a result is able to serve many more workers. The Japanese program serves more than ten times as many workers, despite Japan having only about 40 percent of the population of the United States.

If the American SCSEP program is to meet the needs of as large a proportion of the older population as the Japanese SHRC program does, some structural changes will 
be needed to broaden its mandate so that it is not primarily a poverty program for older workers. The Japanese variant is designed to meet the needs of all older workers independent of their income and wage levels. Clearly, it is important that the needs of the elderly poor be met at least as well as they are being met today, but they might be better met in a program designed for workers from a wide range of income levels. Alternatively, an entirely new program could be developed for the U.S., with the mandate to target a very wide income range without a focus on the poor, but with a focus on meeting the needs of all workers who would like to remain in the labor force up to and hopefully beyond Social Security's normal age of retirement.

The potential effectiveness of the SCSEP program for increasing labor force participation rates among older workers in the United States is due to older workers' preference to be part-time workers in their old age. Since its inception, SCSEP was designed to provide those in need of work mainly with part-time employment opportunities. As discussed earlier, Japan's higher labor force participation rates among older workers may be due, at least in part, to the greater percentage who are selfemployed (Figure 10) or part-time workers (Figure 11). In the United States, according to data from the Health and Retirement Study, ${ }^{114}$ approximately three-quarters of older workers report they would prefer to phase down from full-time work to part-time work. Additionally, about two-thirds of those who plan to keep working after their first retirement report they would work only as part-time workers, according to a 2003 AARP report based on a survey. ${ }^{115}$ If SCSEP improves its capacity to match prospective

\footnotetext{
114 Benitez-Silva (2002).

115 AARP (2003).
} 
employers with part-time workers and older workers, it could eventually contribute to an increase in labor force participation rates among older workers in the United States.

SCSEP could be expanded to become a nationwide public facility tasked to provide job training that is currently provided outside SCSEP. In comparison with Japan, in the U.S. public efforts to provide job training for older people with an eye to eventual employment are much less effective. ${ }^{116}$ For instance, the Comprehensive Employment and Training Act of 1973, a major federal job skills program, provided job training to only one percent of the approximately seven million persons age 45 and older who were eligible for the program. The Job Training Partnership Act of 1982 subsequently replaced the Comprehensive Employment and Training Act of 1973. Despite being a nationwide program, only 8,423 older workers in the entire country were involved in the regular job training programs between July 1992 and June $1993 .{ }^{117}$ Here, our suggestion is that such a job skills program for older workers be integrated into SCSEP as one of its main services. As Japan's SHRC has already demonstrated, it can be an effective strategy to integrate both public and private sector actors into job programs for older workers. The result tends to be training that better fits prospective jobs making the trainee more marketable. A similar strategy would make sense for SCSEP in the United States as well.

On the one hand, the Japanese government uses SHRC as a public program to help older workers find prospective employers. On the other hand, outside of SHRC, other efforts have been initiated to link employers to older workers. A variety of subsidy programs have been implemented to provide employers with financial incentives to foster

\footnotetext{
116 LaLonde (1995).

${ }^{117}$ Bendick (1989).
} 
older workers' continual employment ${ }^{118}$ and re-employment ${ }^{119}$ after age 60 . These efforts can be understood as a public request for employers to contribute to increasing labor force participation among older workers. Such nationwide public intervention with employers can hardly be observed in the United States. Following the experience of Japan, we argue that policymakers in the United States may need to develop a series of subsidy programs designed to promote greater efforts by employers to retain their older workers and more outreach to older workers when hiring.

\section{Suggestion 3: If the U.S. government were to increase various forms of support for older workers seeking to become self-employed, this might increase labor force participation for those age 60 and over.}

Our third suggestion for policy makers in the United States, based on what seems to be working in Japan, is to increase funding for programs benefiting older workers seeking to become self-employed. Many such workers will need some training and some funding to get their own small businesses off the ground. The Japanese government takes a much more active role in labor market policy and in promoting employment opportunities for all workers, including older workers, than does the U.S. government. If the goal is to get an increased number of older American workers to remain in the labor force, a more interventionist and less market-driven approach may be called for.

\footnotetext{
${ }^{118}$ As mentioned earlier, the most important subsidy program for employers to keep employing workers age 60 and older is know as the Subsidy to Promote Continuous Employment of Older Persons.

${ }^{119}$ The program for employers to provide older employees with the training and education necessary for their re-employment in other workplaces is known as the Subsidy to Promote Re-Employment of Older Employees Approaching Mandatory Retirement Age. According to the Cabinet Office (2006), this subsidy has been provided for those employers who meet certain criteria designed to measure how successfull they are in providing their older employees with assistance they need to find re-employment.
} 
As mentioned earlier, the fraction of Japanese workers who are self-employed is substantially higher than in the United States (Figures 10 and 11). One factor contributing to the high rates of self-employment among older Japanese workers is the prevalence of well-funded government programs designed to facilitate the transition at age 60 or so (depending on the employer's mandatory retirement age) from being an employee to being self-employed. In connection with such programs (e.g., Partial Subsidy to Promote Older Persons’ Business and Self-Employment Opportunities), the government provides financial support for older workers seeking to start their own businesses. Based on the evidence from Japan, it would be reasonable to argue that more support for such programs would potentially increase labor force participation rates among older workers in the United States. While such programs do exist in the United States, they service a far more modest fraction of the older population. For example, the Self Employment Assistance Program reaches older workers in only seven states. In contrast the comparable program in Japan is national.

\section{References}

AARP. 2003. "Staying Ahead of Curve 2003: The AARP Working in Retirement Survey." Retrieved September 8, 2006.

(http://assets.aarp.org/rgcenter/econ/multiwork_2003.pdf).

ABC News. 2006. “ABC News Original Report, Retired Husband Syndrome: Wives Get Frustrated When Their Husbands Are Retired." Retrieved November 1, 2006. (http://abcnews.go.com/GMA/AmericanFamily/story?id=1491039).

Amano, Masako. 2001. Dankai Sedai: Sinron [The Dankai Generation: A New Approach]. Tokyo: Yūshindō Kōbunsha.

Aoi, Kazuo. 2004. "Bebii Būmu kara Bebii Bāsuto e" [From Baby Boom to Baby Bust] Kazoku Shakaigaku Kenkyū [Japanese Journal of Family Sociology] 15(2):5-6. 
Bass, Scott A. 1996. "An Overview of Work, Retirement, and Pension in Japan.” Journal of Aging \& Social Policy 8(2-3):57-78.

BBC News. 2006. "Norway's Welfare Model 'Helps Birth Rate'.” March 28. Retrieved November 21, 2006. (http://news.bbc.co.uk/go/pr/fr/-/hi/world/europe/4786160.stm).

Béland, Daniel. 2005. Social Security: History and Politics from the New Deal to the Privatization Debate. Kansas: University Press of Kansas.

Bendick, Marc. 1989. "Matching Workers and Job Opportunities: What Roles for the Federal-State Employment Service.” Pp. 81-108 in Rethinking Employment Policy, edited by D.L. Bawden and S.A. Skidmore. Washington D.C.: Urban Institute.

Benitez-Silva, Hugo. 2002. "Job Search Behavior at the End of the Life Cycle." Working Paper 2002-10. Chestnut Hill, MA: Center for Retirement Research at Boston College.

Blanchflower, David G. 2004. "Self-Employment: More May Not Be Better”. Working Paper Number 10286. Cambridge, MA: National Bureau of Economic Research.

Retrieved August 28, 2006. (http://www.nber.org/papers/W10286.pdf).

Board of Trustees, Federal Old Age and Survivors Insurance and Disability Insurance Trust Funds. 2006. "The 2006 Annual Report of the Trustees of the Federal Old-Age and Survivors Insurance and Disability Insurance Trust Funds.” Retrieved November 5, 2006. (http://www.ssa.gov/OACT/TR/TR06/).

Bongaarts, John. 2004. "Population Aging and the Rising Cost of Public Pensions." Population and Development Review 30(1):1-23.

Brinton, Mary C. 2000. "Social Capital in the Japanese Youth Labor Market: Labor Market Policy, Schools, and Norms." Policy Sciences 33(3):289-306.

Broadbent, Jeffrey P. 2000. "Social Capital and Labor Politics in Japan: Cooperation or Cooptation?” Policy Sciences 33(3-4):307-321.

Bureau of Labor Statistics, United States Department of Labor. Current Population Survey. 2003. "Employment and Earnings, June 2003." Retrieved August 24, 2006. (http://www.findarticles.com/p/articles/mi_m2553/is_6_50/ai_109847239).

The Cabinet Office, Government of Japan. 2000. White Paper on Aging Society, 2000 Edition. Tokyo: Office of Government Public Relations.

The Cabinet Office, Government of Japan. 2001. "The Fifth Cross-National Survey on the Living Conditions and Consensus among Older People." Retrieved August 20, 2006. (http://www8.cao.go.jp/kourei/ishiki/h12_kiso/2-5.pdf). 
The Cabinet Office, Government of Japan. 2006. White Paper on Aging Society, 2006 Edition. Tokyo: Office of Government Public Relations.

Clark, Robert L. and Naohiro Ogawa. 1997. "Transitions from Career Jobs to Retirement in Japan." Industrial Relations 36(2):255-270.

Curl, Angela L. and M. C. 'Terry’ Hokenstad, Jr. 2006. "Reshaping Retirement Policies in Post-Industrial Nations: The Need for Flexibility." Journal of Sociology and Social Welfare 33(2):85-106.

Diamond, Peter and Peter Orszag. 2004. Saving Social Security: A Balanced Approach. Washington D.C.: The Brookings Institution.

Dixon, John. 1999. Social Security in Global Perspective. Connecticut: Praeger Publishers.

The Economist. 2003. "Keep It Up: The French Family.” The Economist, May 3, 367:53.

Elmelech, Yuval. 2005. "Attitudes toward Familial Obligation in the United States and in Japan.” Sociological Inquiry 75(4):497-526.

Employment \& Training Administration, U.S. Department of Labor. 2006. "SelfEmployment Assistance." Retrieved August 19, 2006.

(http://www.ows.doleta.gov/unemploy/self.asp).

Everingham, Christine. 2002. "Engendering Time: Gender Equity and Discourses of Workplace Flexibility." Time \& Society 11(2-3):335-351.

Faiola, Anthony. 2005. "Sick of Their Husbands in Graying Japan: Stress Disorder Diagnosed in Many Women After Spouses Retire.” Washington Post, Oct. 17, A01.

Fujimura, Masayuki. 2004. "Raifukōsu ni Okeru Kaiko to Shūgōteki Kioku - Chūkōnen no Seikatsu Keiken to Shakai Ishiki Chōsa Bunseki Kara" [Retrospections and Collective Memories from a Life Course Perspective: An Analysis of Life Experiences and Opinions of the Middle Aged and the Aged]. Sahakaigaku Ronsh $\bar{u}$ [Sociological Research Collections] 28(Mar.):23-44. Tokyo: Shakaigakka Jōchi Daigaku.

Hagiwara, Motoaki. 1972. "The Socializing Function of the School." The Journal of Educational Sociology 27(Oct.): 40-50.

Hakuhōdō Elder Business Promotion Office. 2005. "Hope Report XV Dankai Generation Husbands Research, Year 2004.” Retrieved August 4, 2006.

(http://www.hhope.net/knowledge/hope_report/hope19/index.html). 
Harris, Phyllis Braudy and Susan Orpett Long. 1999. "Husbands and Sons in the United States and Japan: Cultural Expectations and Caregiving Experiences." Journal of Aging Studies 13(3):241-267.

Haveman, Robert, Karen Holden, and Barbara Wolfe. 2003. "Social Security, Age of Retirement, and Economic Well-Being: Intertemporal and Demographic Pattern among Retired-Worker Beneficiaries.” Demography 40(2):369-394.

Higuchi Yoshio. 2004. Dankai Sedai no Teinen to Nihon Keizai [Retirement of the Dankai Generation and the National Economy]. Tokyo: Nihon Hyōronsha.

Honda, Yuki. 2005. “'Freeters': Young Atypical Workers in Japan.” Japan Labor Review 2(3):5-25.

Inglehart, Ronald F., Miguel Basanez, and Alejandro Moreno. 1998. Human Values and Beliefs: A Cross-Cultural Sourcebook. Michigan: The University of Michigan Press.

International Labor Organization (ILO), International Labor Statistics - LABORSTA Internet. 2005a. "Economically Active Population." Retrieved August 10, 2006. (http://laborsta.ilo.org/applv8/data/cle.html).

International Labor Organization (ILO), International Labor Statistics - LABORSTA Internet. 2005b. "Total Economically Active Population.” Retrieved August 12, 2006. (http://laborsta.ilo.org/).

International Labor Organization (ILO), International Labor Statistics - LABORSTA Internet. 2006. “Total Economically Active Population.” Retrieved August 12, 2006. (http://laborsta.ilo.org/).

Japan Aging Research Center. 2004. "Nippon no Chūkōnen Jijyō-Chūkōnen no Shügyō" [Current Living Conditions of the Middle-Aged and Old People in Japan: Their Labor Force Participation]. Tokyo: Japan Aging Research Center Press.

Japan Health Promotion and Fitness Foundation. 2006. "Kenkou Nippon 21" [Healthy Japan in the $21^{\text {st }}$ Century]. Retrieved September 23, 2006. (http://www.kenkounippon21.gr.jp/).

Japan Institute for Labor Policy and Training. 2005. Labor Situation in Japan and Analysis 2004/2005. Tokyo: Daitō Press.

Japan Organization for Employment of Older Persons and Persons with Disabilities. 2004. Elder, the April issue. Tokyo: Sanwa Press. 
Japan Organization for Employment of Older Persons and Persons with Disabilities. 2005. Kōreishakai Tōkei Yōran [Handbook of Labor Statistics on Aged Society]. Tokyo: Sanwa Press.

Kagiyama, Norimitsu and Shigetomo Ōta. 2001. "Nihon ni Okeru Rōdō Shijō no Tokushitsu to Shihyō 2001 Nen Ban" [The Characteristics and Criteria of Employment Conditions in Japan, 2001 Edition]. Tokyo: Hakuhō Shobō.

Karoly, Lynn A. and Julie Zissimopoulos. 2004. "Self-Employment among Older U.S. Workers." Monthly Labor Review, 127(Jul.):24-47. Retrieved August 29, 2006. (http://www.bls.gov/opub/mlr/2004/07/art3full.pdf\#search=\%22selfemployment\%20among\%20older\%20U.S.\%20workers\%22).

Kimura, Takeshi and Masato Oka. 2001. “Japan's Current Policy Focus on Longer Employment for Older People." Pp. 348-359 in Restructuring Work and the Life Course, edited by V.W. Marshall, W.R. Heinz, H. Kruger, and A. Verma. Ontario: University of Toronto Press.

Kiyokawa, Yukihiko and Hiroko Yamane. 2004. "Nihonjin no Kinrōkan-Ishiki Chōusa ni Miru Sono Henkan" [Japanese Attitude toward Working: The Transition of the Attitude toward Working Found in Existing Opinion Surveys]. Ōhara Shakaimondai Kenkyüjo Zasshi [Ōhara Research Institute for Social Problems] 542(Jan.):14-33.

Kosugi, Reiko. 2004a. "Changes in Employment Style: Atypical Employment and Individualism among Young Workers." Shakaigaku Hyōron [Japanese Sociological Review] 54(4):355-369.

Kosugi, Reiko. 2004b. "The Transition from School to Work in Japan: Understanding the Increase in Freeter and Jobless Youth.” Japan Labor Review 1(1):52-67.

LaLonde, Robert. J. 1995. "The Promises of Public Sector-Sponsored Training Programs.” Journal of Economic Perspectives 9(2):149-168.

Long, Susan Orpett and Phyllis Braudy Harris. 2000. "Gender and Elder Care: Social Change and the Role of the Caregiver in Japan." Social Science Japan Journal 3(1):2136.

MacKellar, Landis and David Horlacher. 2000. "Population Ageing in Japan: A Brief Survey." Innovation 13(4):413-430.

Maeda, Nobuhiko. 2005. "Teinen Taishoku Katei no Jendā Hikaku” [A Comparative Study of Gender Differences in Retirement Processes]. Shakaigaku Hyōron [Japanese Sociological Review] 56(1):55-72. 
Maeda, Nobuhiko. 2006. Akutyibu Eijingu no Shakaigaku - Kōreisha, Shigoto, Nettowāku [Toward a Sociology of Active Aging: the Elderly, Work, and Network]. Tokyo: Mineruva Shobō.

Ministry of Health, Labor, and Welfare. 2002. White Paper on Labor and Welfare, 2002. Tokyo: Office of Government Public Relations.

Ministry of Health, Labor, and Welfare. 2003. Survey of Conditions of Older Workers' Labor Force Participation in Japan. Tokyo: Office of Government Public Relations.

Ministry of Health, Labor, and Welfare. 2004. White Paper on Aging Society. Tokyo: Office of Government Public Relations.

Ministry of Health, Labor, and Welfare. 2005. White Paper on Aging Society. Tokyo: Office of Government Public Relations.

Ministry of Health, Labor, and Welfare. 2006a. "Kōreisha Koyō Antei Hō no Kaisei ni Tsuite" [The Partial Amendment of the Law Concerning Stabilization of Employment of Older Persons]. Retrieved September 21, 2006. (http://www.mhlw.go.jp/general/seido/anteikyoku/kourei2/qa/index.html).

Ministry of Health, Labor and Welfare. 2006b. "Outline, Kenkou Nihon 21" [The National Campaign for Promoting Health in the $21^{\text {st }}$ Century]. Retrieved July 28, 2006. (http://www1.mhlw.go.jp/topics/kenko21_11/pdf/s0.pdf).

Misumi, Nifuji and Takuya Yamori. 1993. "Nihonjin no Kinrō Kachikan - Dainikai Hataraku Koto no Imi ni Kansuru Kokusaihikaku Kara" [What are the Meanings of Working to Japanese?: An Analysis of the Second Cross-National Survey on Meaning of Working]. Soshiki Kagaku [Organizational Sciences] 26(4): 83-96.

Miura, Noboru. 2005. Dankai Sedai o Sōkatsu Suru [Overview of Dankai Generation's Life Style]. Tokyo: Makino Shuppansha.

Moen, Phyllis, Kim E. Jungmeen, and Heather Hofmeister. 2001. "Couples' Work/Retirement Transitions, Gender, and Marital Quality.” Social Psychology Quarterly 64(1):55-71.

Mouer, Ross and Hirosuke Kawanishi. 2005. A Sociology of Work in Japan. New York: Cambridge University Press.

Murray, Christopher J. L., Sandeep C. Kulkarni, Catherine Michaud, Niels Tomijima, Maria T. Bulzacchelli, Terrell J. Iandiorio, and Majid Ezzati. 2006. "Eight Americas: Investigating Mortality Disparities across Races, Countries, and Race-Counties in the United States." Public Library of Science: Medicine 3(9):1513-1524. Retrieved September 25, 2006. (http://medicine.plosjournals.org/archive/15491676/3/9/pdf/10.1371_journal.pmed.0030260-L.pdf). 
Myles, John. 1984. Old Age in the Welfare State: The Political Economy of Public Pensions. Boston: Little Brown.

Nariai, Osamu. 1999. History of the Modern Japanese Economy. Tokyo: Foreign Press Center.

National Center for Health Statistics, Department of Health and Human Services. 2005. Health, United States, 2005. Maryland: CDC National Center for Health Statistics Press.

National Silver Human Resource Center Corporation. 2006a. "Outlines of the Business Operations." Retrieved August 10, 2006. (http://www.zsjc.or.jp/rhx/about/2_1.html).

National Silver Human Resource Center Corporation. 2006b. "Active Ageing - National Statistics.” Retrieved August 4, 2006. (http://www.zsjc.or.jp/rhx/upload/Statistics/2.pdf).

Nippon Atomized Metal Powders Corporation. 2006. "Company Data." Retrieved September 23, 2006. (http://www.atomize.co.jp/data_cd.html).

Ōishi, Akiko. 2000. "Kōreisha no Shūgyō Kettei ni Okeru Kenkō Yōin no Eikyō" [Effects of Health on the Participation of Elderly Workers in the Labor Force]. Nihon Rōdō Kenkyū Zasshi [The Monthly Journal of the Japan Institute of Labor] 481(Aug.):5162.

Okamura, Kiyoko 1987. "Teinen Taishokusha no Shūgyō Fushūgyō to Sono Kettei Yōin" [Factors for Retired Older Workers to Decide to Re-enter the Labor Force: Case Studies of Older People in Their Early 60s in Tokyo]. Shakai Rōreigaku [Social Gerontology] 26(Aug.):3-17.

Okamura, Kiyoko. 2001. "Ima Dankei Sedai Wa" [The Dankai Generation, Today]. Pp. 32-59 in Dankaisedai Shinron - Shakaiteki Jiritsu o Hiraku [A New Approach to the Dankai Generation - Toward Their Autonomy in Social Relations], edited by M. Amano. Tokyo: Yūshindō Kōbunsha.

Ono, Hiroshi and Kristen Schults Lee. 2006. "Specialization and Happiness: A US-Japan Comparison." Working Paper Series 631 in Economic and Finance. Stockholm: Stockholm School of Economics. Retrieved October 27, 2006. (http://swopec.hhs.se/hastef/papers/hastef0631.pdf

Organization for Economic Co-operation and Development (OECD). 2001. Labor Market Statistics: 2001 Edition. Paris: Organization for Economic Co-operation and Development.

Organization of Economic Development and Co-operation (OECD). 2005a. Economic Survey of the United States 2005: Ensuring Fiscal Sustainability and Budgetary Discipline. Paris: Organization for Economic Co-operation and Development. 
Organization for Economic Co-operation and Development (OECD). 2005b. Labor Force Statistics, 1984-2004. Paris: Organization for Economic Co-operation and Development.

Organization for Economic Co-operation and Development (OECD). 2005c. Extending Opportunities: How Active Social Policy Can Benefit Us All. . Paris: Organization for Economic Co-operation and Development. Retrieved December 6, 2006. (http://www.oecd.org/dataoecd/31/16/34530748.pdf).

Organization of Economic Development and Co-operation (OECD). 2006a. Pension Reforms and the Development of Pension Systems: An Evaluation of World Bank Assistance. Paris: Organization for Economic Co-operation and Development.

Organization of Economic Development and Co-operation (OECD). 2006b. Economic Survey - United States 2004: Sustaining Strong Growth and Social Cohesion: Key Challenges. Paris: Organization for Economic Co-operation and Development.

Organization for Economic Co-operation and Development (OECD) 2006c. "Selection of OECD Pensions at a Glance 2005 Indicators: How Does Your Country Compare?" Retrieved September 12, 2006. (http://www.oecd.org/dataoecd/7/54/35385805.xls).

Research Institute for Hi-Life. 2003. "Dankai Sedai Fūfu no Yukue ni Kansuru Chōsa Kenkyū" [Study of the Gender Dynamics between Husbands and Wives in the Dankai Generation]. Retrieved September 12, 2006. (http://www.hilife.or.jp/pdf/20033.pdf).

Rix, Sara E. 1996. "The Challenge of an Aging Work Force: Keeping Older Workers Employed and Employable.” Journal of Aging \& Social Policy 8(2/3):79-96.

Sasatani, Harumi. 2005. "Kazoku Kaigosha Shiten Kara no Kaigo no Shakaika BunsekiKazoku Mondai Kenkyū Kara Mita Gendai Kazoku no Igi to Imi" [The Position of Family in the Caregiving System for the Elderly - An Analysis of "Socialization" of Care from the Family Career Perspective]. Kazokushakaigaku Kenkyū [Japanese Journal of Family Sociology] 16(2):36-46.

Satō, Hiroki, Atsushi Sato, Eiichi Oki, and Takuma Kimura. 2005. Dankai Sedai no Raifu Dezain [The Life-Design of the Dankai Generation]. Tokyo: Chūōhōki.

Seike, Atsushi. 1993. Kōreika Shakai no Rōdōshijyō - Shūgyō Kōdō to Kōteki Nenkin Teinen [The Labor Market in Aging Society: A Study of Employment Behaviors, Mandatory Retirement, and Public Pension Benefits]. Tokyo: Tōyōkeizai Shinpōsha.

Seike, Atsushi. 2003. "Kōreisha no Koyō to Kōteki Nenkin Nenreikijun no Koyōseido Jintekishihon Tōshi” [On Older Workers' Employment, the Public Pension Structure, Age-Related Public Policies for Employment, and Investments in Human Resources] Mita Shōgakukenkyū [Mita Business Studies] 46(3):93-105. 
Seike, Atsushi._2005. Kōreishakai Nihon no Koyō Seisaku [Policies for Aging Workplace in Japan]. Tokyo: Akashishoten.

Seike, Atsushi. 2006. Sekai no Kōreika to Koyōseisaku - Eiji Frendorii na Seisaku ni Yoru Shügyō Kikai no Kakudai ni Mukete [The Ageing World and Employment Policies: Toward Expansion of Employment Opportunities with Age-Friendly Policies]. Tokyo: Akashishoten.

Seike, Atsushi and Atsuhiro Yamada. 2004. Kōreisha Shūrou no Keizaigaku [The Economics of Older Workers' Labor Force Participation]. Tokyo: Nihon Keizai Shinbunsha.

Seike, Atsushi and Atsuhiro Yamada. 2006. The Work and Retirement Behavior of Older People in Japan: An Analysis Using Employment Status Survey: 1982-2002. Tokyo: Office of Government Public Relations.

Senior Community Service Employment Program, U.S. Department of Labor Employment \& Training Administration. 2006a. "About SCSEP, Program Description." Retrieved November 2, 2006a.

(http://www.doleta.gov/seniors/html_docs/AboutSCSEP.cfm).

Senior Community Service Employment Program, U.S. Department of Labor Employment \& Training Administration. 2006b. "PY 2004 Performance Results Summary." Retrieved August 9, 2006 b. (http://www.doleta.gov/Seniors/html_docs/GranteePerf.cfm).

Shishido, Kuniaki. 2004. "Kōreiki ni Okeru Kyōdō Katsudō no Imi - Yūenha to Shirenha no Oi no Kōsatsu Kara" [The Meaning of "Collective" Activities in a Later Stage of Life: An Analysis of the Leisure-Oriented and the Purpose-Oriented among Older People]. Soshioroji [Sociology] 49(1):91-107.

Social Insurance Agency, Ministry of Health, Labor, and Welfare. 2006. "The Structure of Public Pension.” Retrieved August 28, 2006. (http://www.sia.go.jp/seido/nenkin/nenkin02.htm).

Sodekawa, Yoshinori, Yukari Hanajima, and Masahiro Morisumi. 2005. Dankai to Dankai Junia no Kazokugaku [The Family Dynamics of the Dankai Generation and Their Children]. Tokyo: Dentsū.

Stanford Program on International and Cross-National Education, Freeman Spogli Institute for International Studies. 2004. Comparative Health Care: The United States and Japan. California: Spice Publications. 
Statistics Bureau, General-Director for Policy Planning \& Statistical Research and Training Institute, Ministry of Internal Affairs and Communications. 2005a. "Trend in the Number of Workers by Type of Work and Age Group" in Survey on the National Labor Force in 2005, (1990-2004). Retrieved August 14, 2006.

(http://www.stat.go.jp/data/roudou/2.htm).

Statistics Bureau, General-Director for Policy Planning \& Statistical Research and Training Institute, Ministry of Internal Affairs and Communications. 2005b. "Defining the Concepts." Retrieved August 24, 2006.

(http://www.stat.go.jp/data/shugyou/2004/2.htm).

Takahashi, Masato. 2001. Oino Shakai Shinrigaku Teki Gakusetsu [Social Psychological Perspectives to Aging]. Tokyo: Hōristu Bunkasha.

Takahashi, Yukichi. 1997. "The Labor Market and Lifetime Employment in Japan." Economic and Industrial Democracy 18(1):55-66.

Takayama, Noriyuki. 2001. "Pension Reform in Japan at the Turn of the Century." The Geneva Papers on Risk and Insurance 26(4):565-574.

Takayama, Noriyuki. 2002. "Saikin no Nenkin Ronsō to Sekai no Nenkin Dōkō" [The Current Debate on the Public Pension Structure and the World Trends of Public Pension Schemes]. Keizaikenkyū [Economic Studies] 53(3):268-284.

Vallas, Steven P. 1999. "Rethinking Post-Fordism: The Meaning of Workplace Flexibility" Sociological Theory 17(1):68-101.

Watanabe, Noriyasu. 2004. "Social Security Reform Ideas in Japan." Journal of Aging \& Social Policy 14(1):81-93.

Weiss, Robert, Scott A. Bass, Harley Heimovits, and Masato Oka. 2005. "Japan's Silver Human Resource Centers and Participant Well-Being." Journal of Cross Cultural Gerontology 20(1):47-66.

Williamson, John B. and Fred C. Pampel. 1993. Old-Age Security in Comparative Perspective. New York: Oxford University Press.

The World Bank. 2005. World Development Report 2006: Equity and Development. Washington D.C.: The World Bank.

World Health Organization (WHO). 2000. "Japan Number One in New 'Healthy Life' System."

Retrieved September 21, 2006. (http://www.int/inf-pr-2000/en/pr2000-life.html). 
World Health Organization (WHO). 2005. Healthy Life Expectancy 2002 from the 2004 World Health Report. Geneva: World Health Organization.

World Health Organization (WHO). 2006a. "Health Situation, Japan." Retrieved October 28, 2006. (http://www.wpro.who.int/NR/rdonlyres/9F3C8334-F0B3-49C4-9593B173F32456D4/0/15_Japan.pdf).

World Health Organization (WHO). 2006b. "The Atlas of Heart Disease and Stroke, Part Six: World Tables.” Retrieved October 31, 2006.

(http://www.who.int/cardiovascular_diseases/en/cvd_atlas_29_world_data_table.pdf).

Yamagami, Toshihiko, Junichi Makino, Tarō Saitō, Toshinori Hara, Yoshio Tachizawa, and Tetsurō Kawauchi. 2003. "2007 Nen: Dankai Sedai ha Dokoe Iku” [Year 2007: Where Is the Dankai Generation Going?]. Ekonomisuto [Economist] Nov. 4, 81:55.

Yamamoto, Yasuo and Haruo Komatani. 2003. Daikai Sedai no Tameno Teinengo no Shigoto to Hatarakikata o Kangaeru [Developing Strategies for the Dankai Generation's Continuous Employment and Their Ideal Work Environment]. Tokyo: Dōbunkan Shuppan.

Yamato, Reiko. 2006. "Changing Attitudes towards Elderly Dependence in Postwar Japan.” Current Sociology 54 (2):273-291.

Yashiro, Naohiro. 1997. Nihon Teki Koyō Kankō no Keizaigaku - Rōdō Shijō no Ryūdōka to Nihon Keizai [The Economics of Japanese-Style Employment Structure:

Transformation of the Labor Market and Japanese Economy]. Tokyo: Nihon Keizai

Shinbunsha.

Yuki, Sōichi. 2003. Dankai Sedai towa Nannanoka? [The Dankai Generation: What Is It?]. Tokyo: Yōsensha Publisher. 


\section{APPENDIX}

Figure 1. Percent economically active among persons age 60 and older in the OECD countries as of 2005

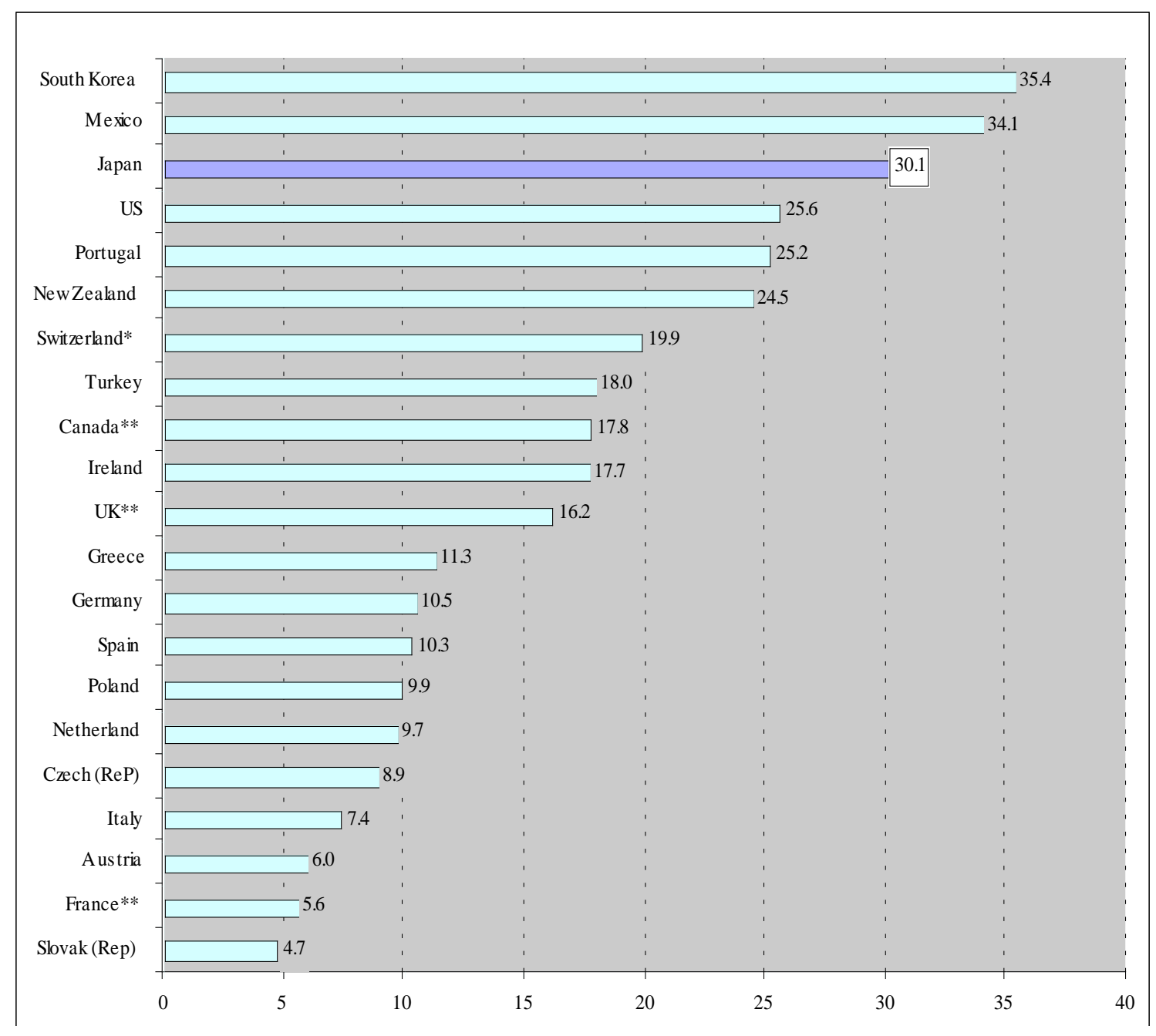

Source: This figure is based on data drawn from ILO (2006) as of 2005 except for:

* Data for Switzerland is obtained from ILO (2005b) as of 2004.

** Data for Canada, France, and UK are obtained from OECD (2006a) as of 2005. 
Figure 2. Percent economically active among persons age 60 to 64 in the OECD countries as of 2005

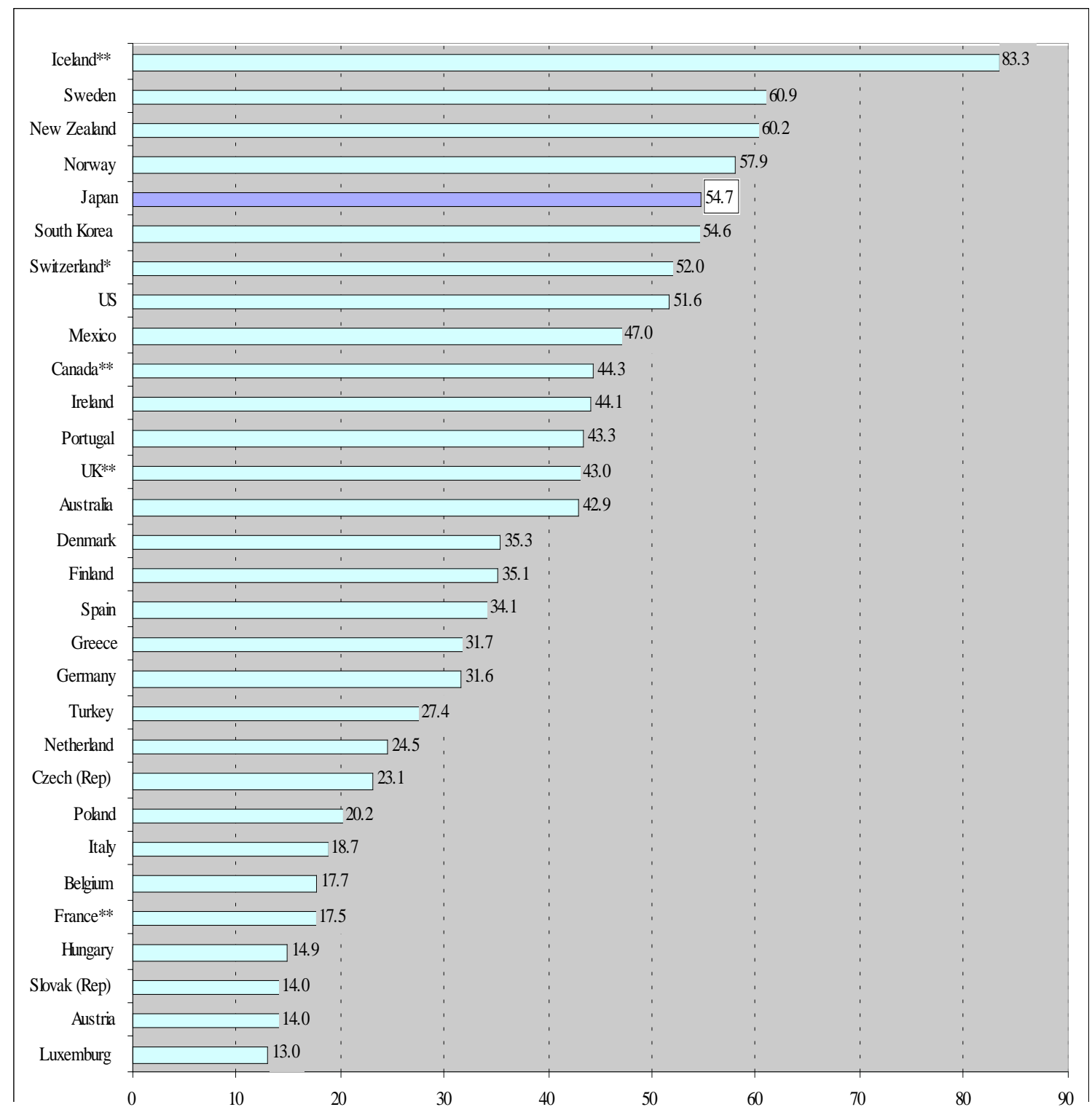

Source: This figure is based on data drawn from ILO (2006) as of 2005 except for:

* Data for Switzerland is obtained from ILO (2005b) as of 2004.

** Data for Canada, France, Iceland, and UK are obtained from OECD (2006a) as of 2005. 
Figure 3. Percent economically active among persons age 65 to 69 in the OECD countries as of 2005

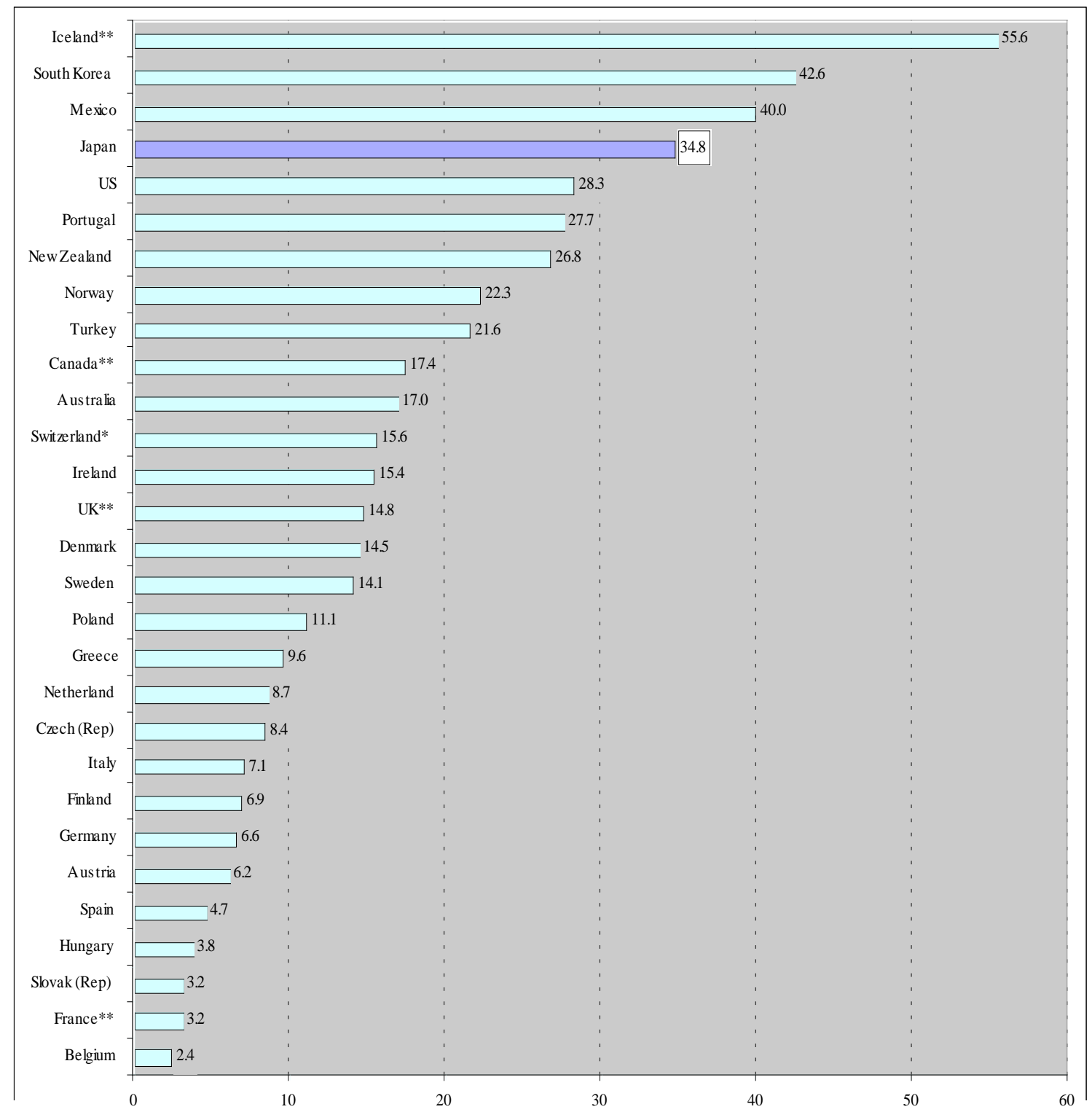

Source: This figure is based on data drawn from ILO (2006) as of 2005 except for:

* Data for Switzerland is obtained from ILO (2005b) as of 2004.

** Data for Canada, France, Iceland, and UK are obtained from OECD (2006a) as of 2005. 
Figure 4. Percent economically active among persons age 70 to 74 in the $O E C D$ countries as of 2005

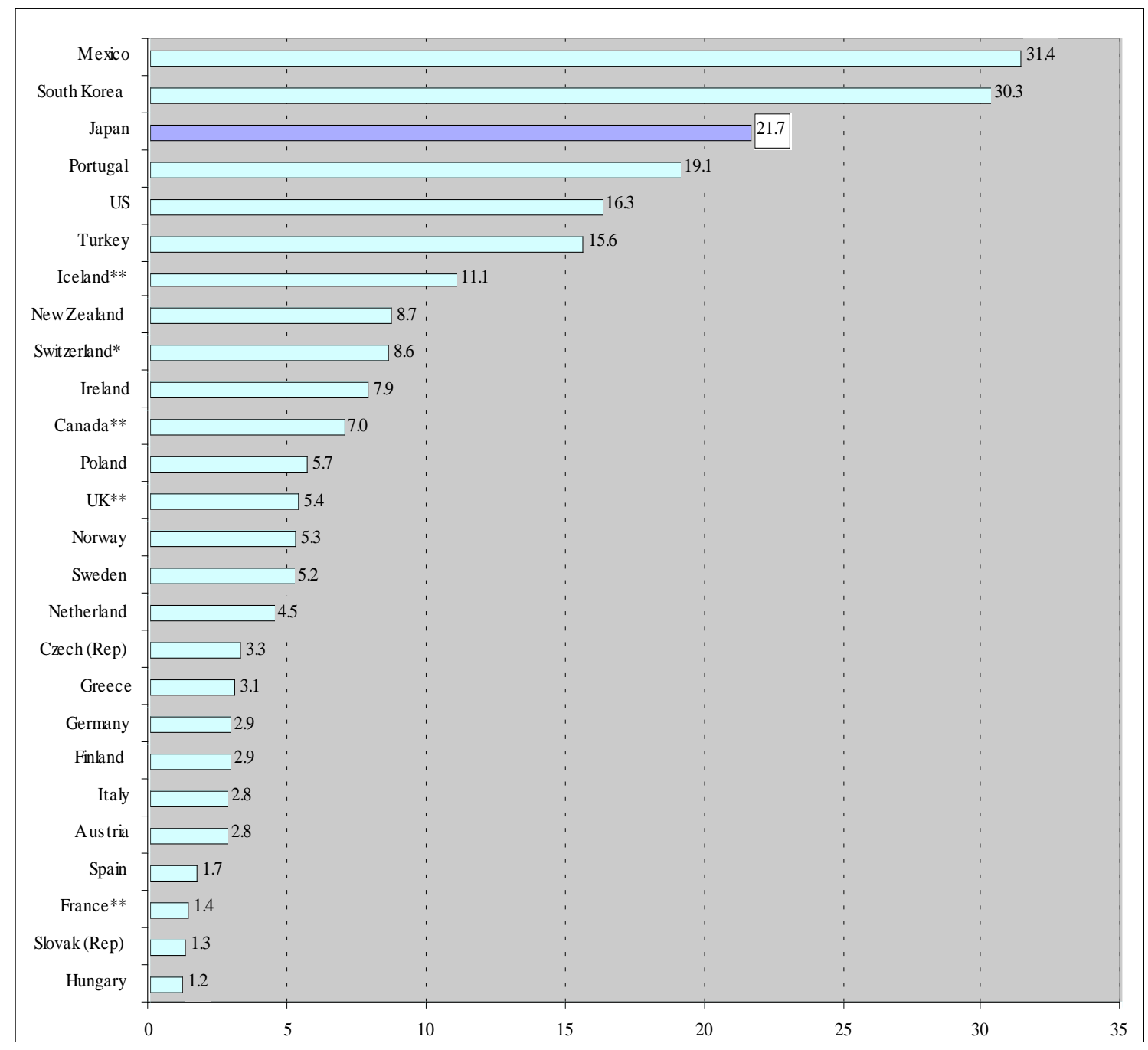

Source: This figure is based on data drawn from ILO (2006) as of 2005 except for:

* Data for Switzerland is obtained from ILO (2005b) as of 2004.

** Data for Canada, France, Iceland, and UK are obtained from OECD (2006a) as of 2005. 
Figure 5. Percent economically active among persons age 75 and older in the OECD countries as of 2005

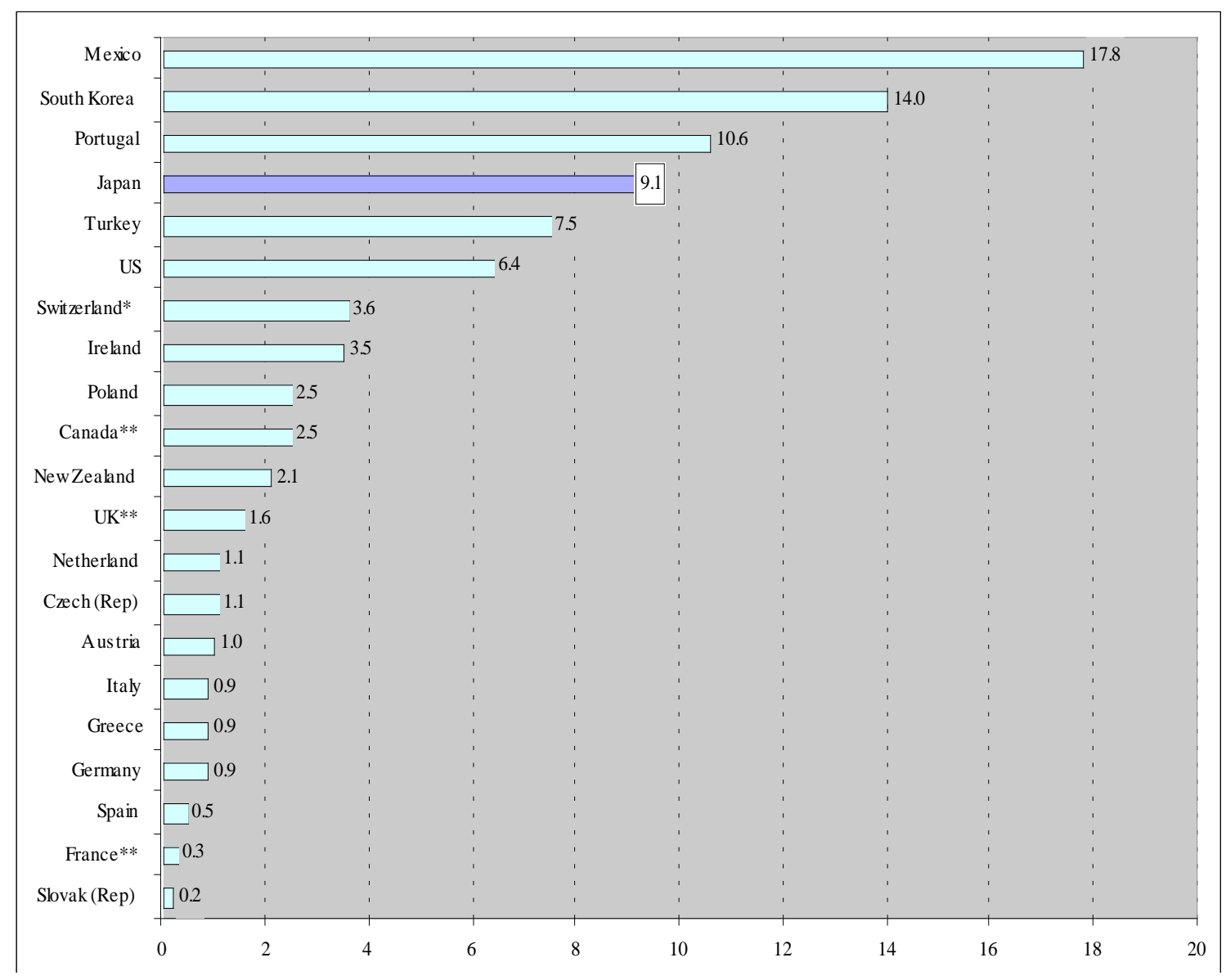

Source: This figure is based on data drawn from ILO (2006) as of 2005 except for:

* Data for Switzerland is obtained from ILO (2005b) as of 2004.

** Data for Canada, France, and UK are obtained from OECD (2006a) as of 2005. 
Figure 6. U.S. vs. Japan comparison, percent economically active by age group as of 2005.

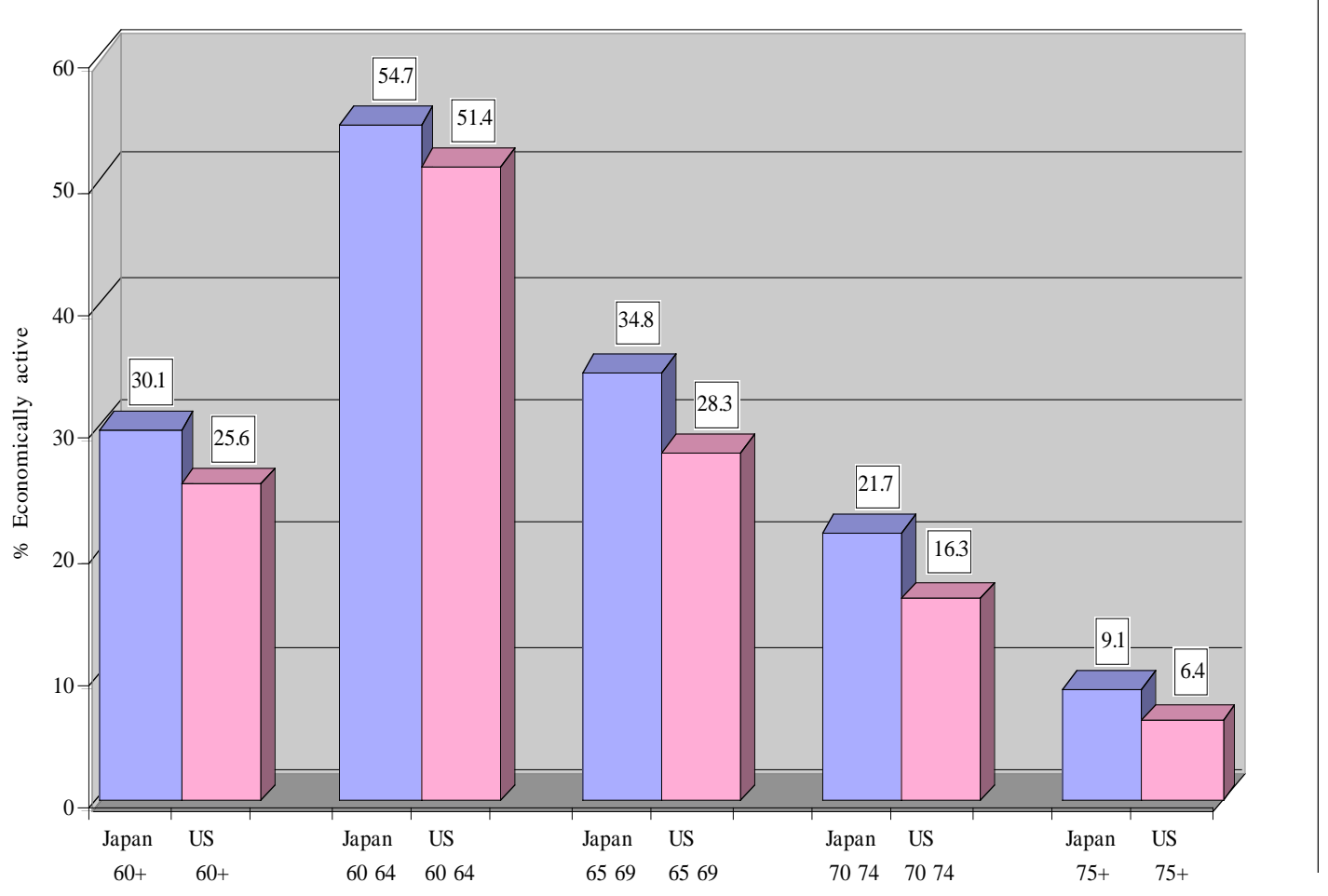

Source: This figure is based on data drawn from ILO (2006). 
Figure 7. U.S. vs. Japan comparison, percent economically active among male workers by age group as of 2005

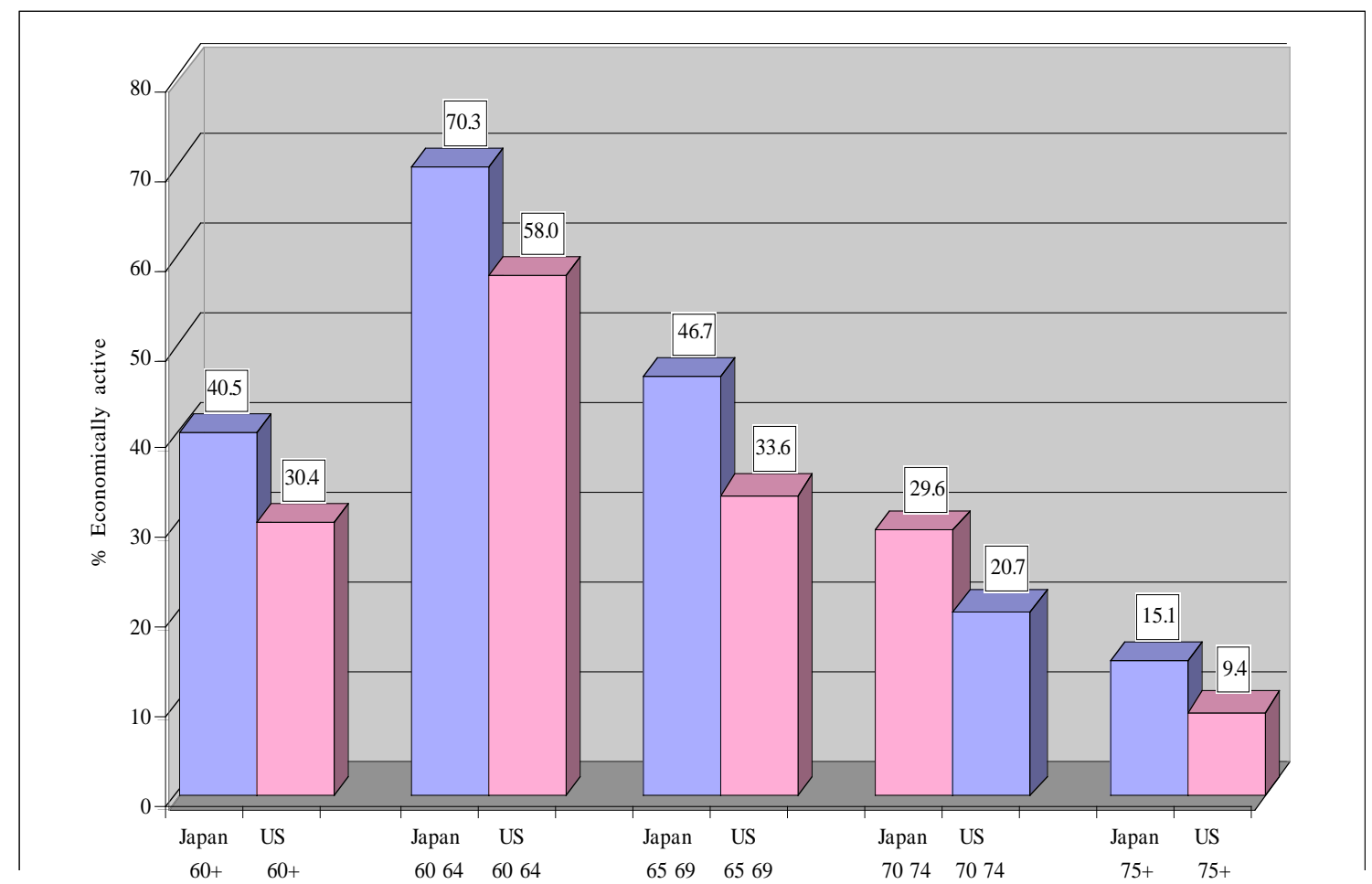

Source: This figure is based on data drawn from ILO (2006). 
Figure 8. Gap percentages of labor force participation rates between Japan and the U.S. as of 2005

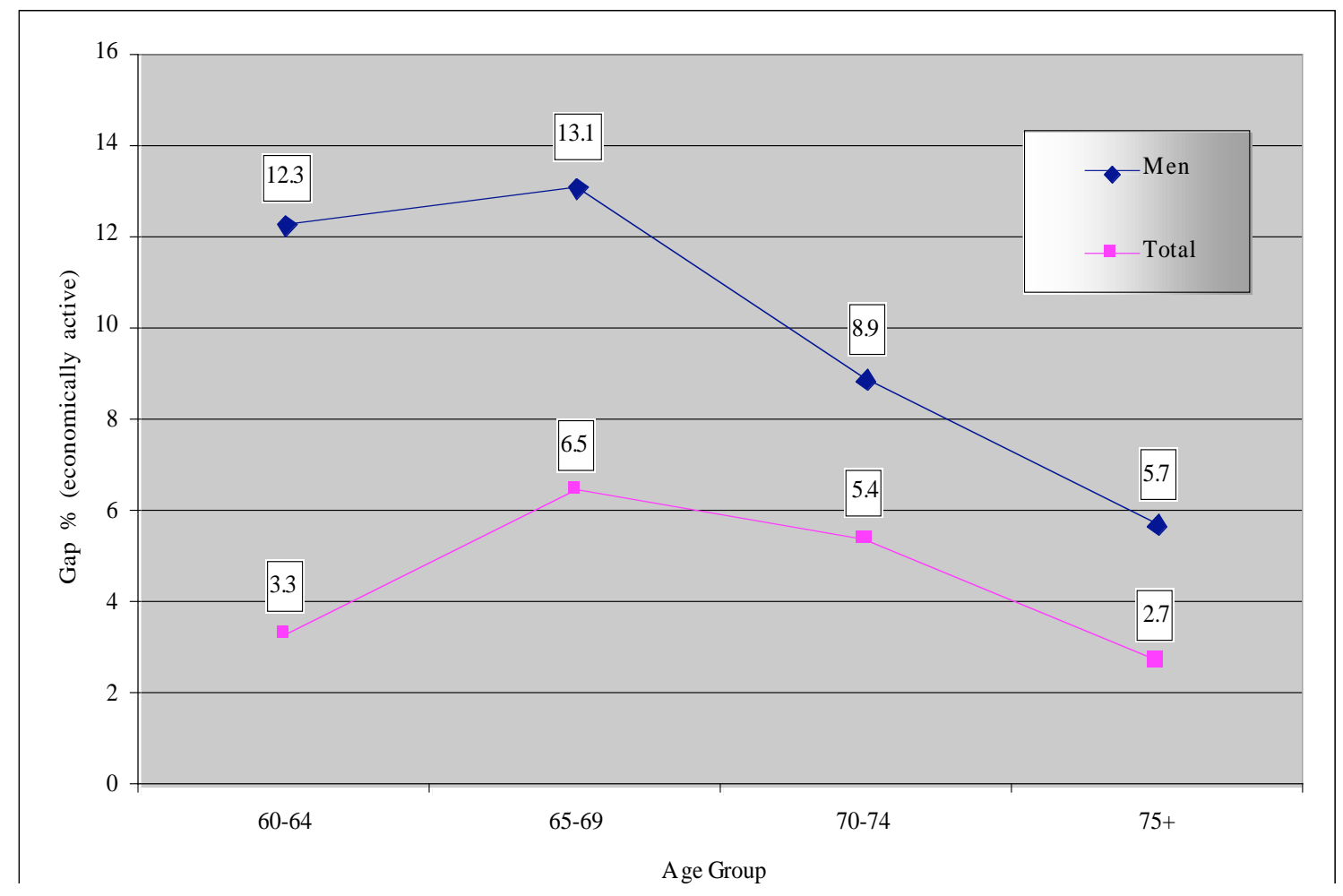

Source: This figure is based on data drawn from ILO (2006). 
Figure 9. U.S. vs. Japan comparison, percent of self-employed among older workers age 60 and older by age as of 2001

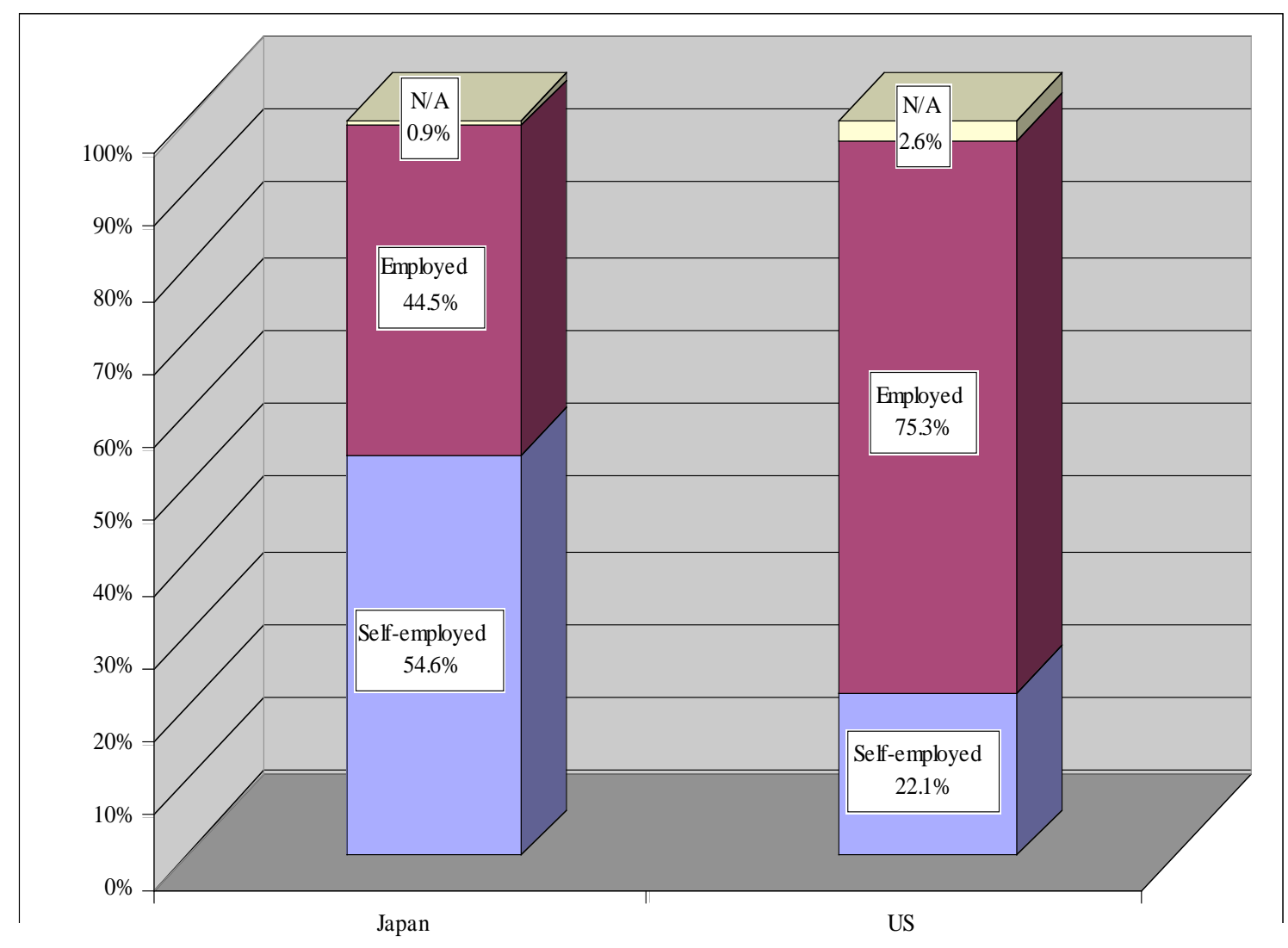

Source: This figure is based on data drawn from the Cabinet Office, Government of Japan (2001). 
Figure 10. U.S. (2002) vs. Japan (2004) comparison, percent of self-employed among older workers by age group

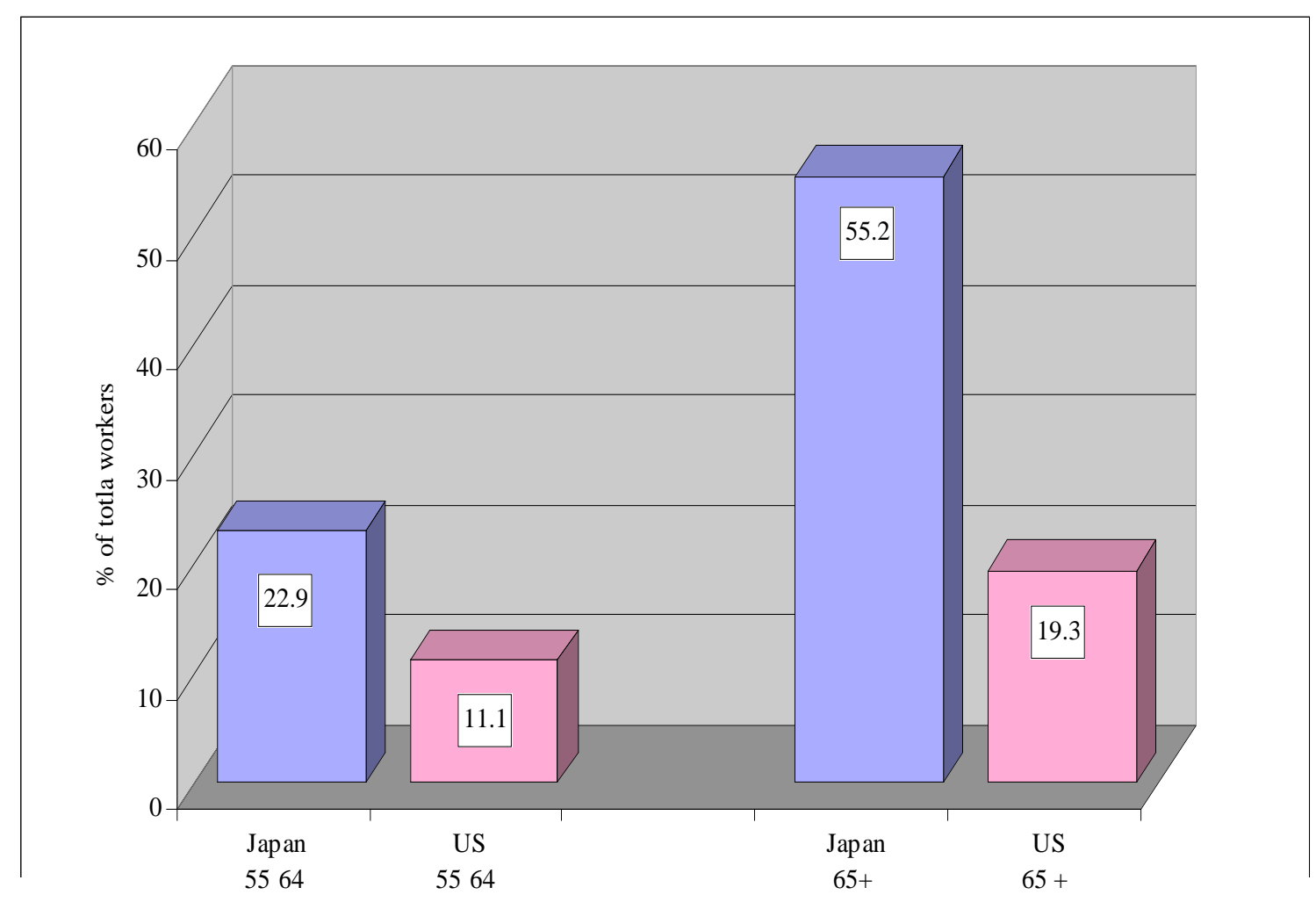

Source: This figure is based on data drawn from Statistics Bureau, General-Director for Policy Planning \& Statistical Research and Training Institute, the Ministry of Internal Affairs and Communications (2005a) ${ }^{120}$ and the Bureau of Labor Statistics, United States Department of Labor (2003). ${ }^{121}$

\footnotetext{
${ }^{120}$ The Ministry of Internal Affairs and Communications defines the self-employed as "those who earn income by individually running business without incorporation and those who engage in wage labor at home, such as working for family businesses." The data presented above includes both workers in agricultural and nonagricultural sectors. See Statistics Bureau (2005b).

${ }^{121}$ The Bureau of Labor Statistics, in its Current Population Survey, defines the self-employed as "those who report they work for themselves in an unincorporated business for their main jobs." Here, the selfemployed excludes the self-employed in incorporated business. The data presented above include both workers in agricultural and nonagricultural sectors. See Bureau of Labor Statistics (2006). "Sources and Footnotes of Tables." Retrieved August 14, 2006 (http://www.bls.gov/news.release/prod2.tfn.htm).
} 
Figure 11. U.S. vs. Japan comparison, percent of part-time workers by age group as of 1999 (\% of total population)

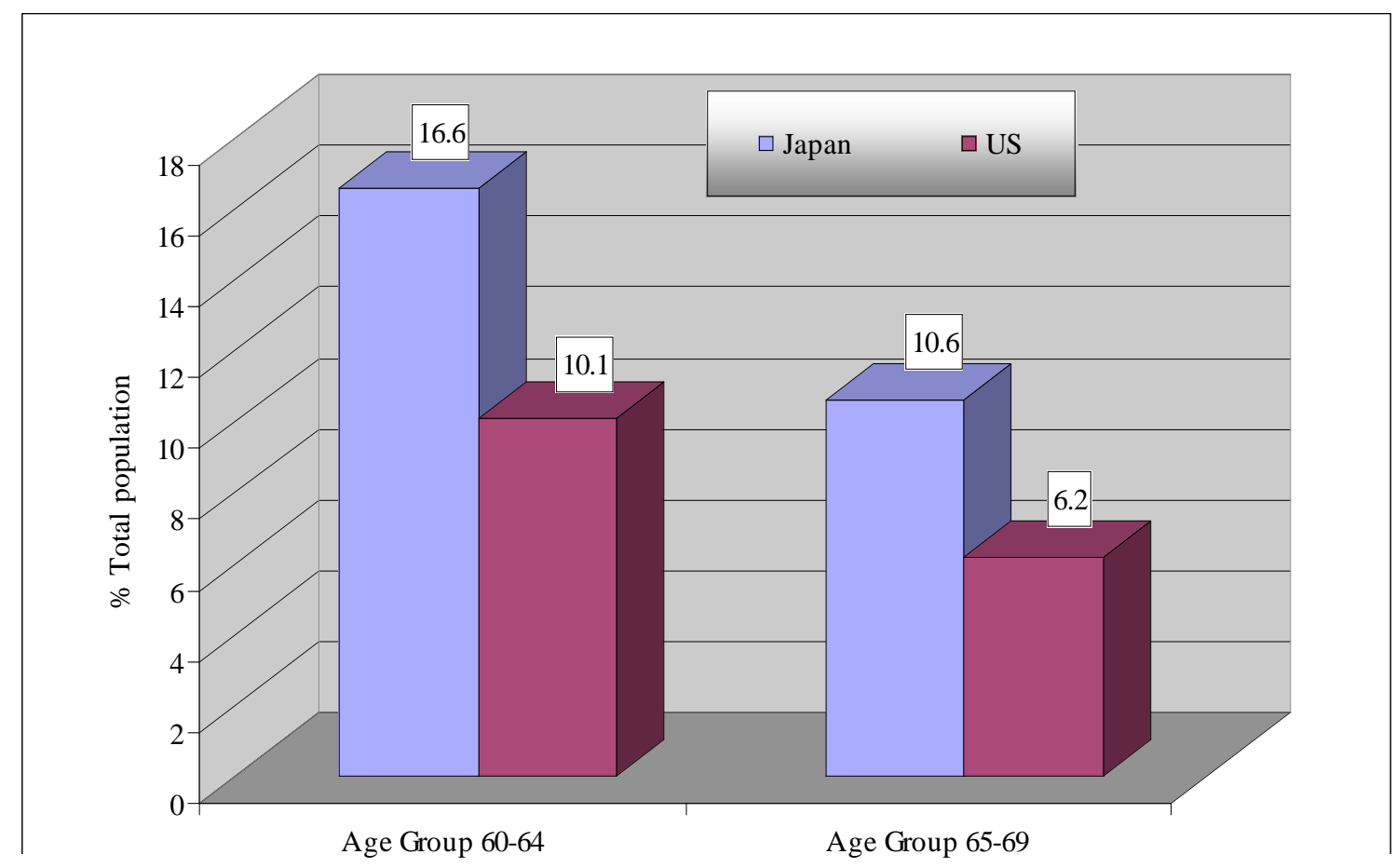

Source: This figure is based on data drawn from OECD (2001) and the Japan Institute for Labor Policy and Training (2005). 
Figure 12. U.S. vs. Japan comparison, percent of employed workers among persons age 60 and older in the specified type of work as of 2000

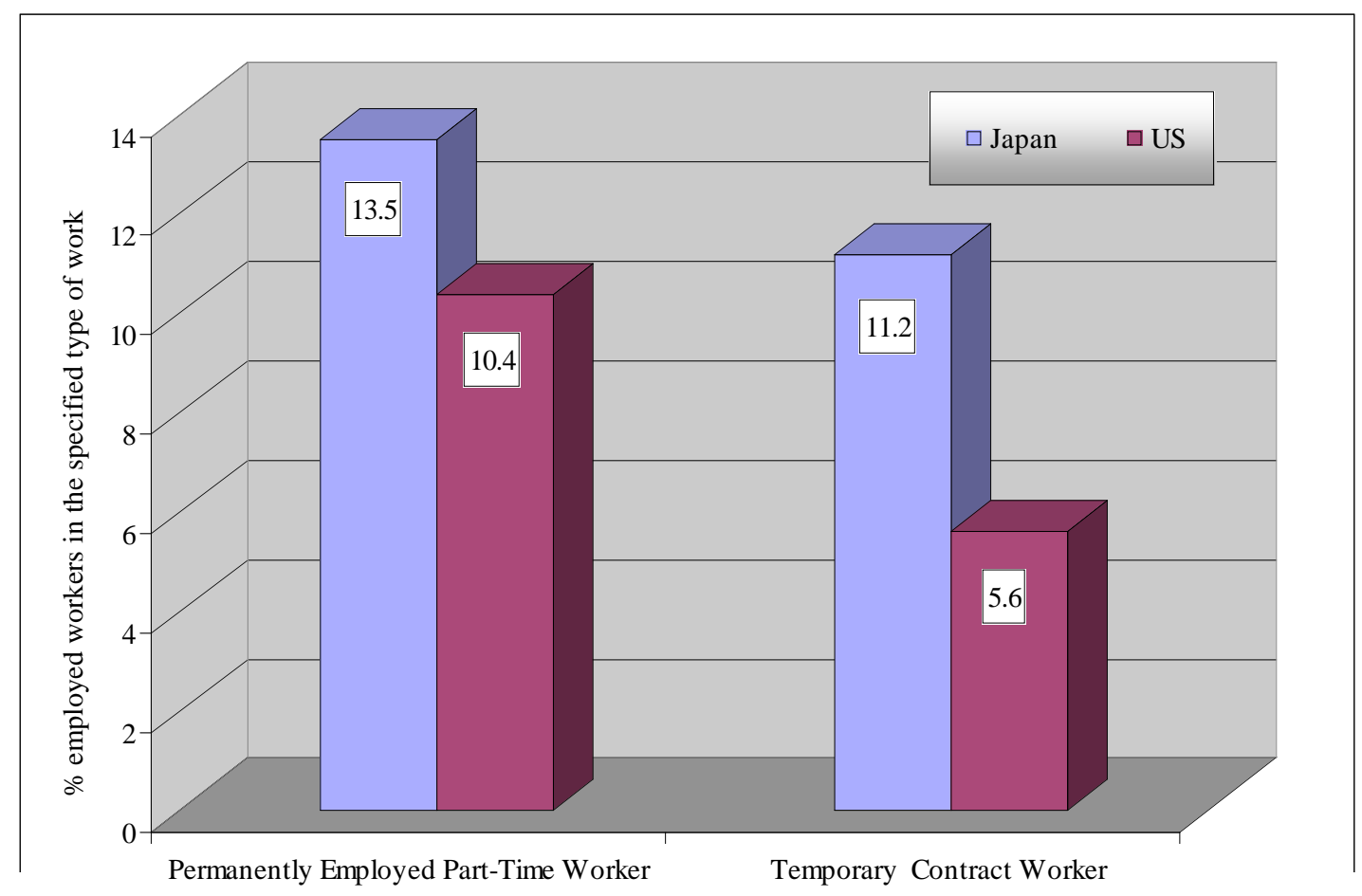

Source: This figure is based on data drawn from the Cabinet Office, Government of Japan (2001). 
Figure 13. Self-report of most important reason why still in labor force, Japanese workers age 60 and older, 2004

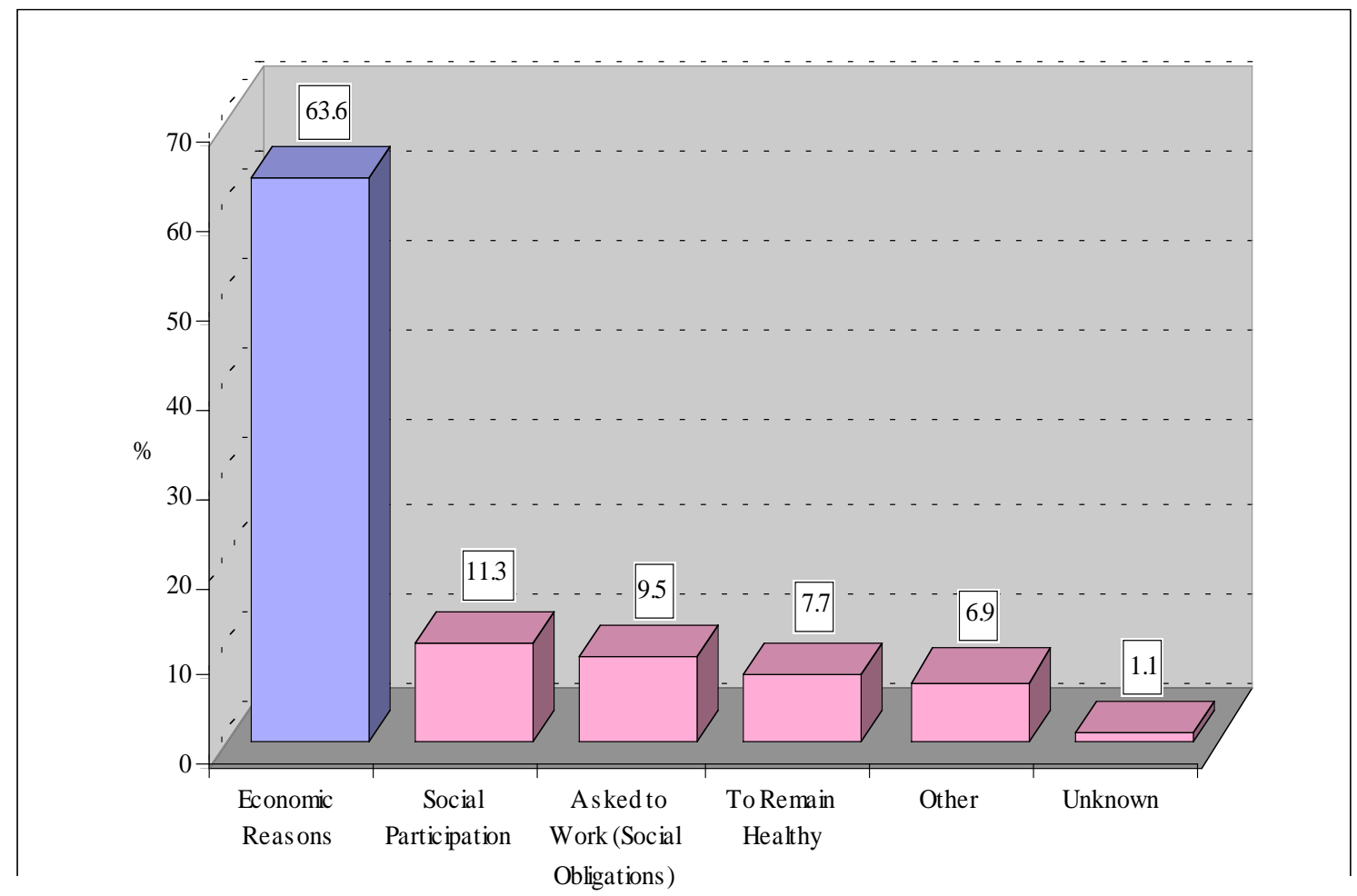

Source: This figure is based on data drawn from the Ministry of Health, Labor, and Welfare (2005). 
Figure 14. Specific "economic reasons" why employed Japanese workers age 60 and over remain in the labor force as of 2004 (\%)

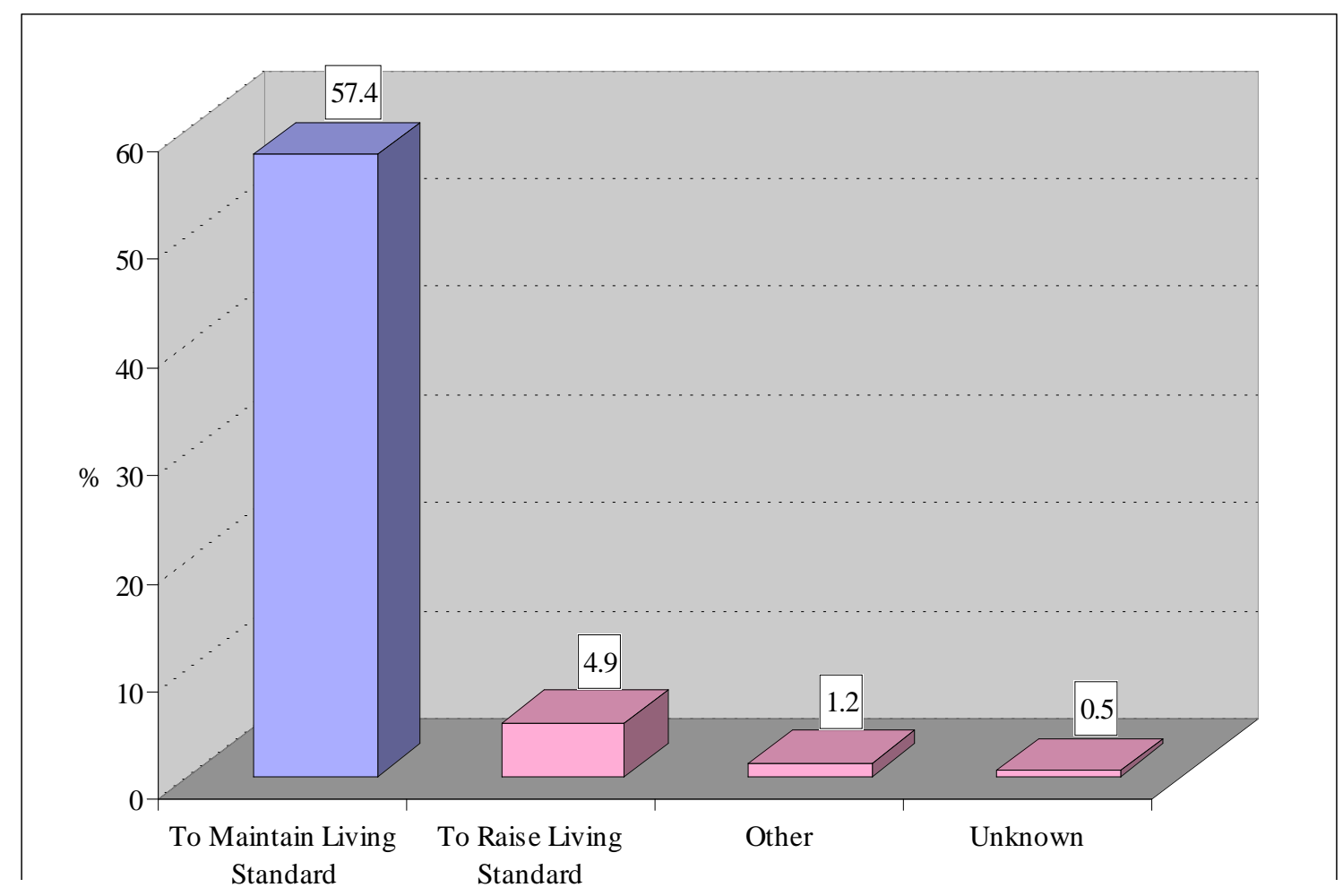

Source: This figure is based on data drawn from the Ministry of Health, Labor, and Welfare (2005). 
Figure 15. Percentage enterprises in all Japanese industrial sectors with fixed mandatory retirement age, by age as of 2002 (\%)

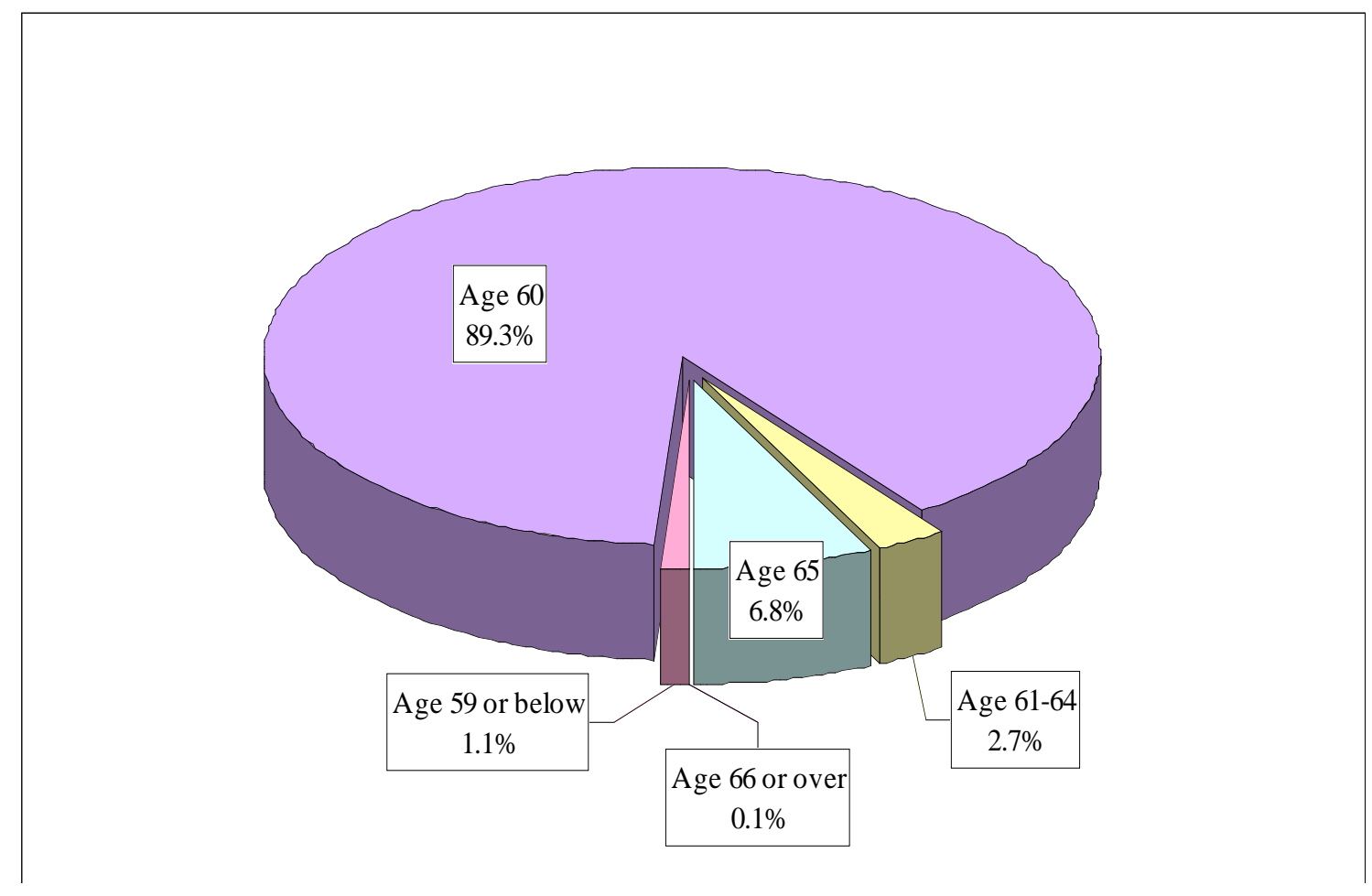

Source: This figure is based on data drawn from the Ministry of Health, Labor, and Welfare (2004) and the Japan Institute for Labor Policy and Analysis (2005). 
Figure 16. Reasons why employed Japanese workers remain in the labor force by age group as of 2004 (\%)

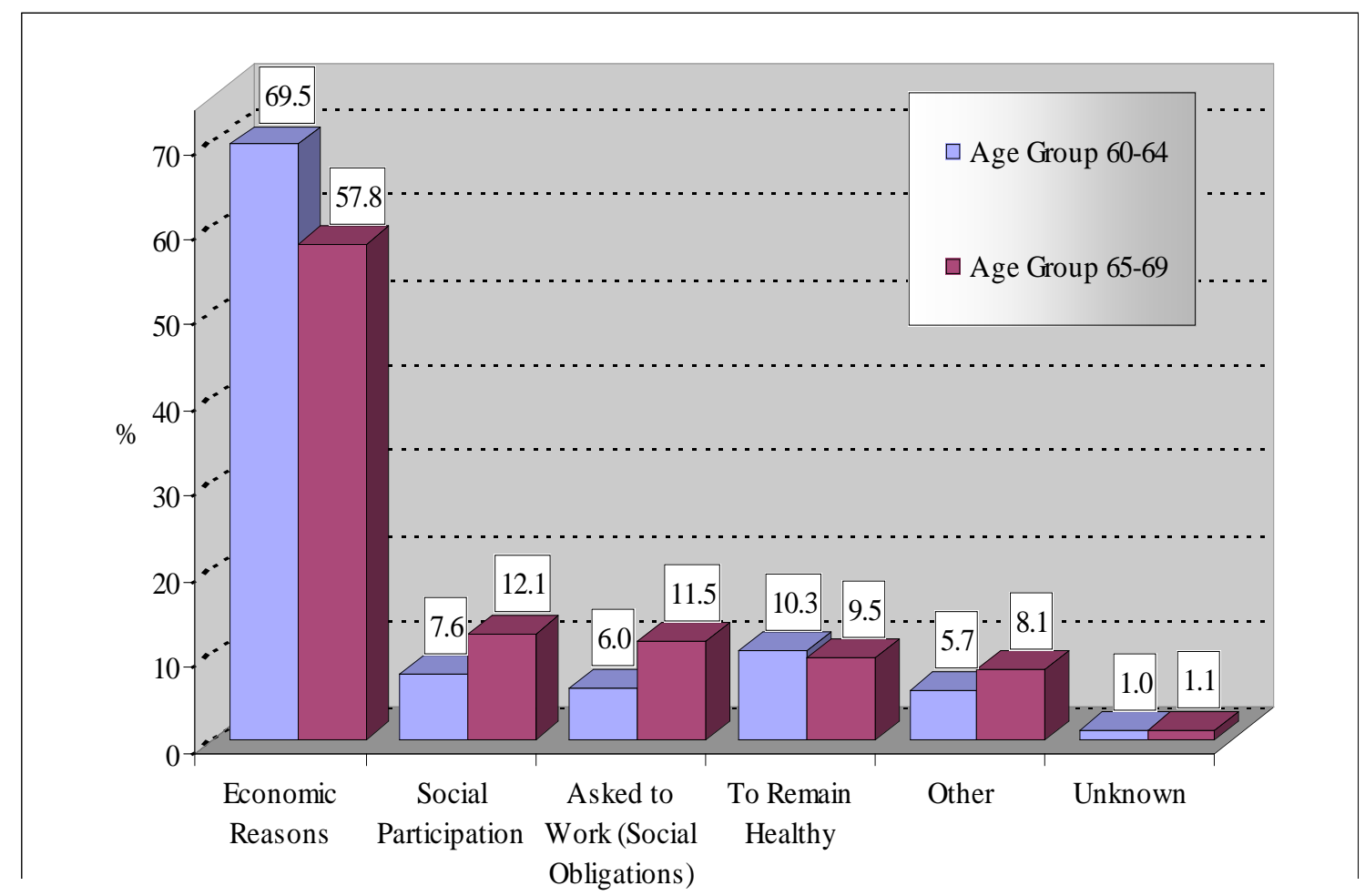

Source: This figure is based on data drawn from the Ministry of Health, Labor, and Welfare (2005). 
Figure 17. U.S. vs. Japan comparison, desired retirement age among persons age 60 and over, working and non-working combined, as of 2000

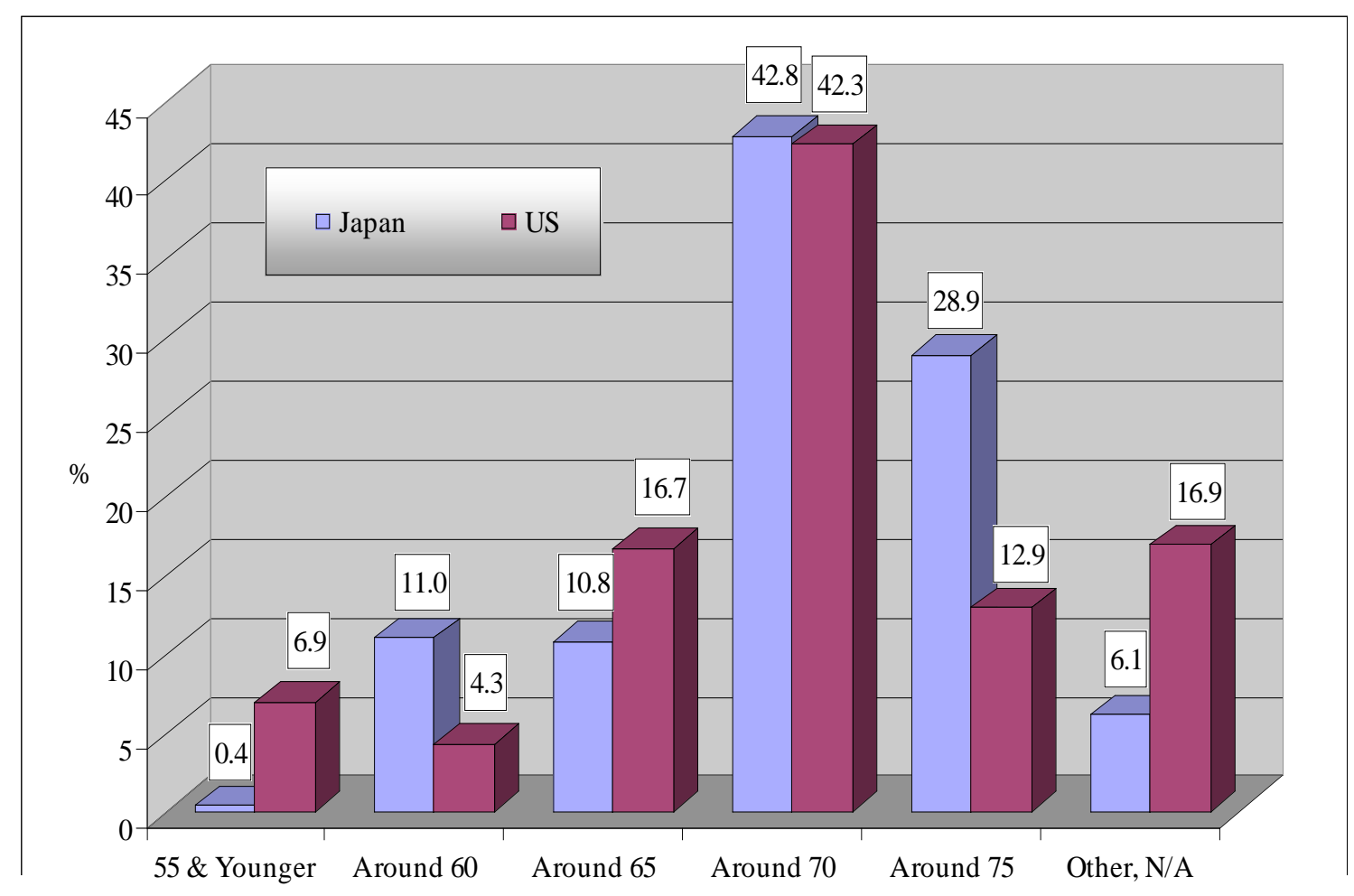

Source: This figure is based on data drawn from the Cabinet Office, Government of Japan (2001). ${ }^{122}$

${ }^{122}$ The respondents of this survey ( $\mathrm{N}=1,000$ per country) are those who are age 60 and older, including those in the labor force and those not working at the time of the survey. 
Figure 18. U.S. vs. Japan comparison, at what age men age 60 and over, working and non-working combined, think they should retire from the labor force in their countries, as of 2000.

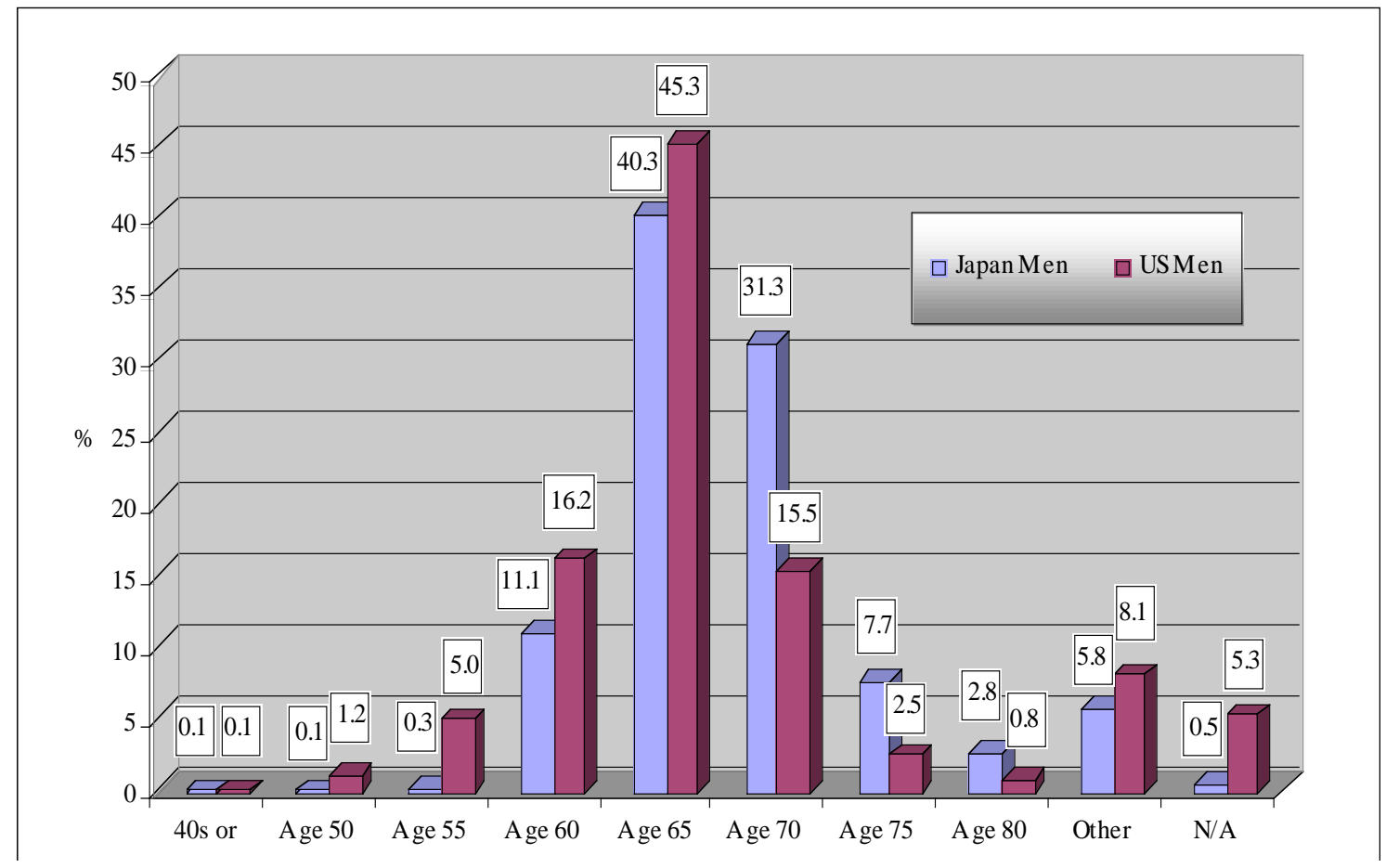

Source: This figure is based on data drawn from the Cabinet Office, Government of Japan (2000). 
Figure 19. Japanese population's collective value for remaining economically productive in response to the survey question, "Would you keep working after retirement even if you have no need to earn money?"

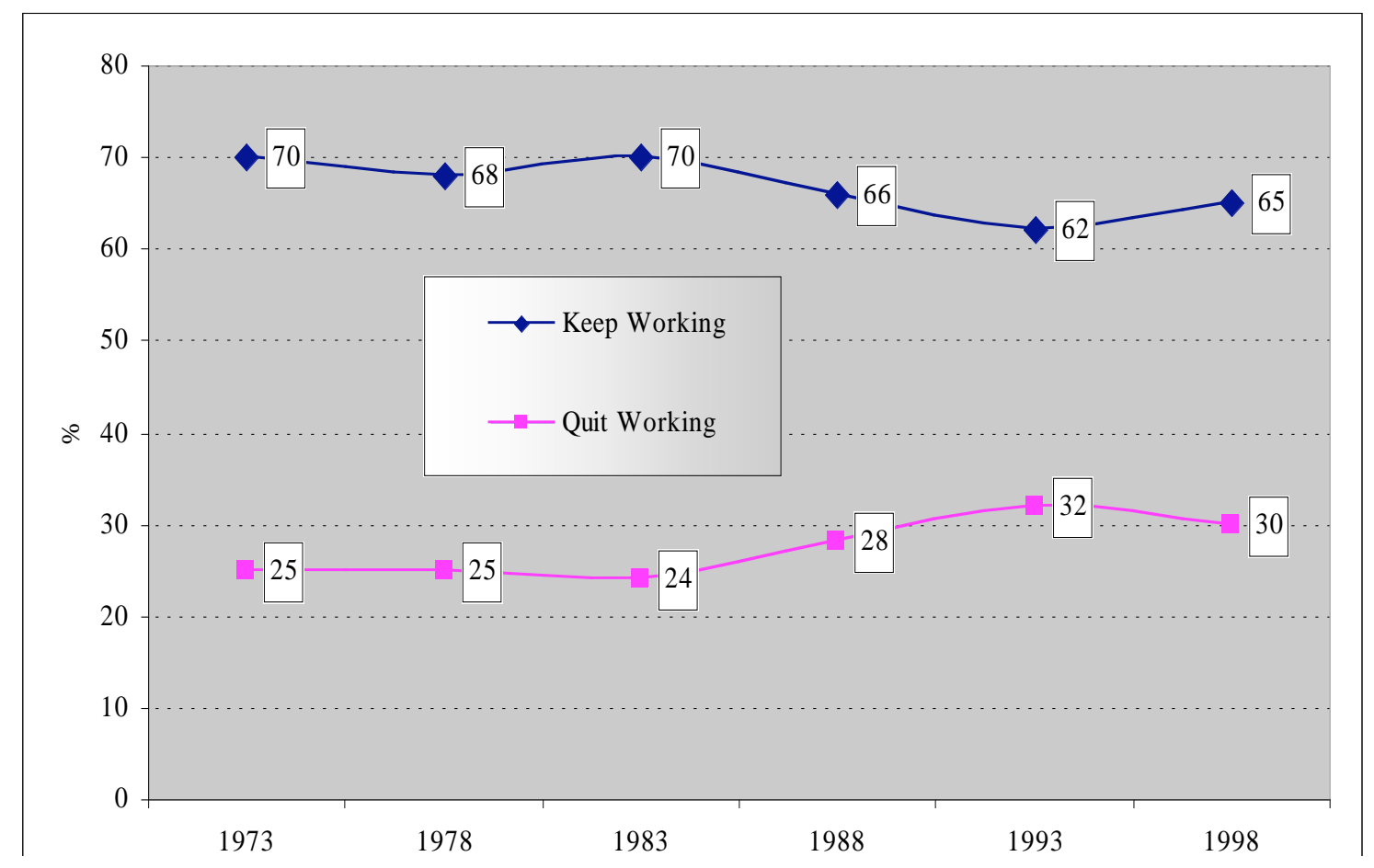

Source: Kiyokawa and Yamane (2004). 
Figure 20. The Silver Human Resource Center, enrollment by gender for years 1989 through 2004

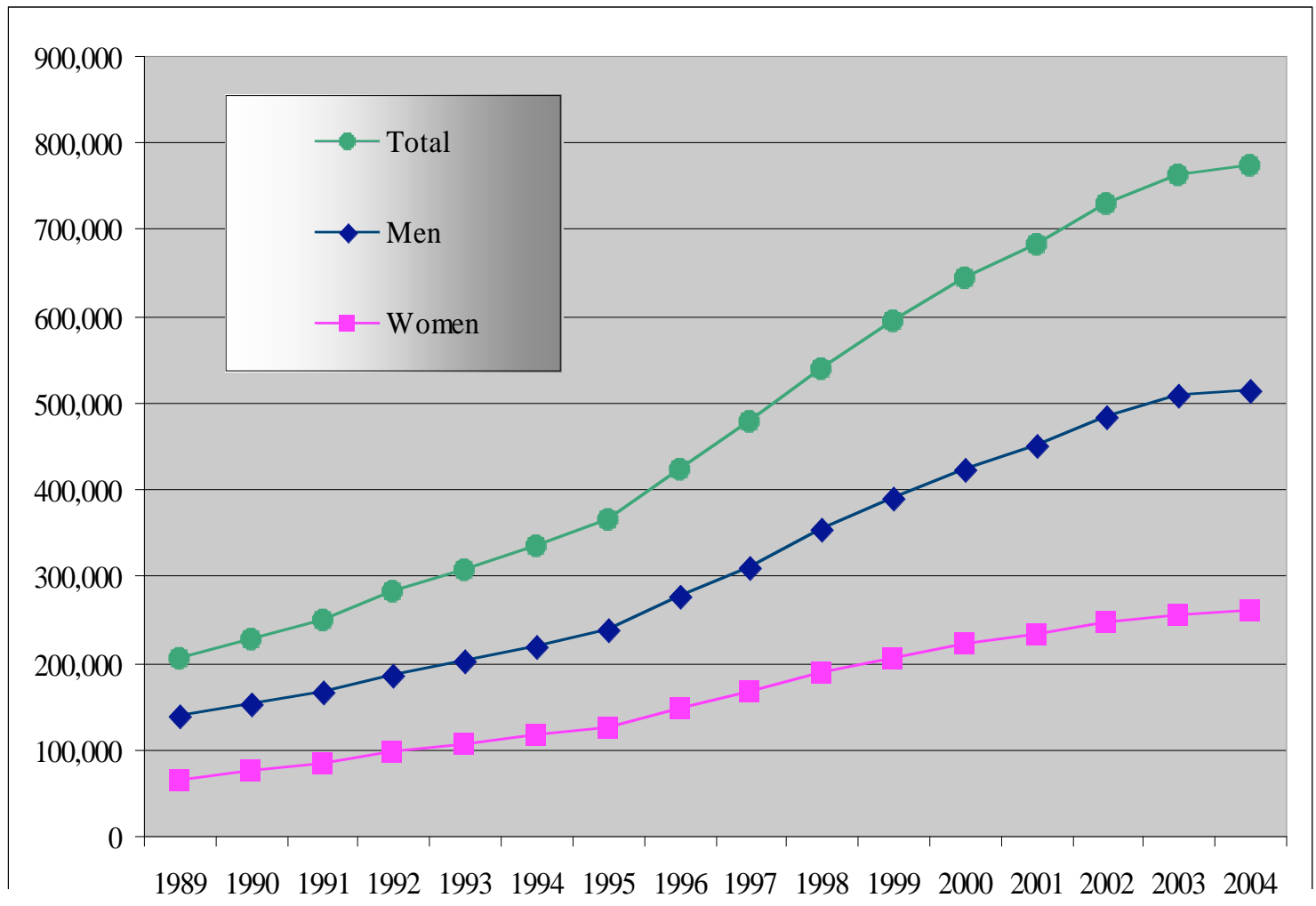

Source: This figure is based on data drawn from National Silver Human Resource Center (2006b). 
Figure 21. The Silver Human Resource Center, trends in total funding and number of branches for years 1989 through 2004

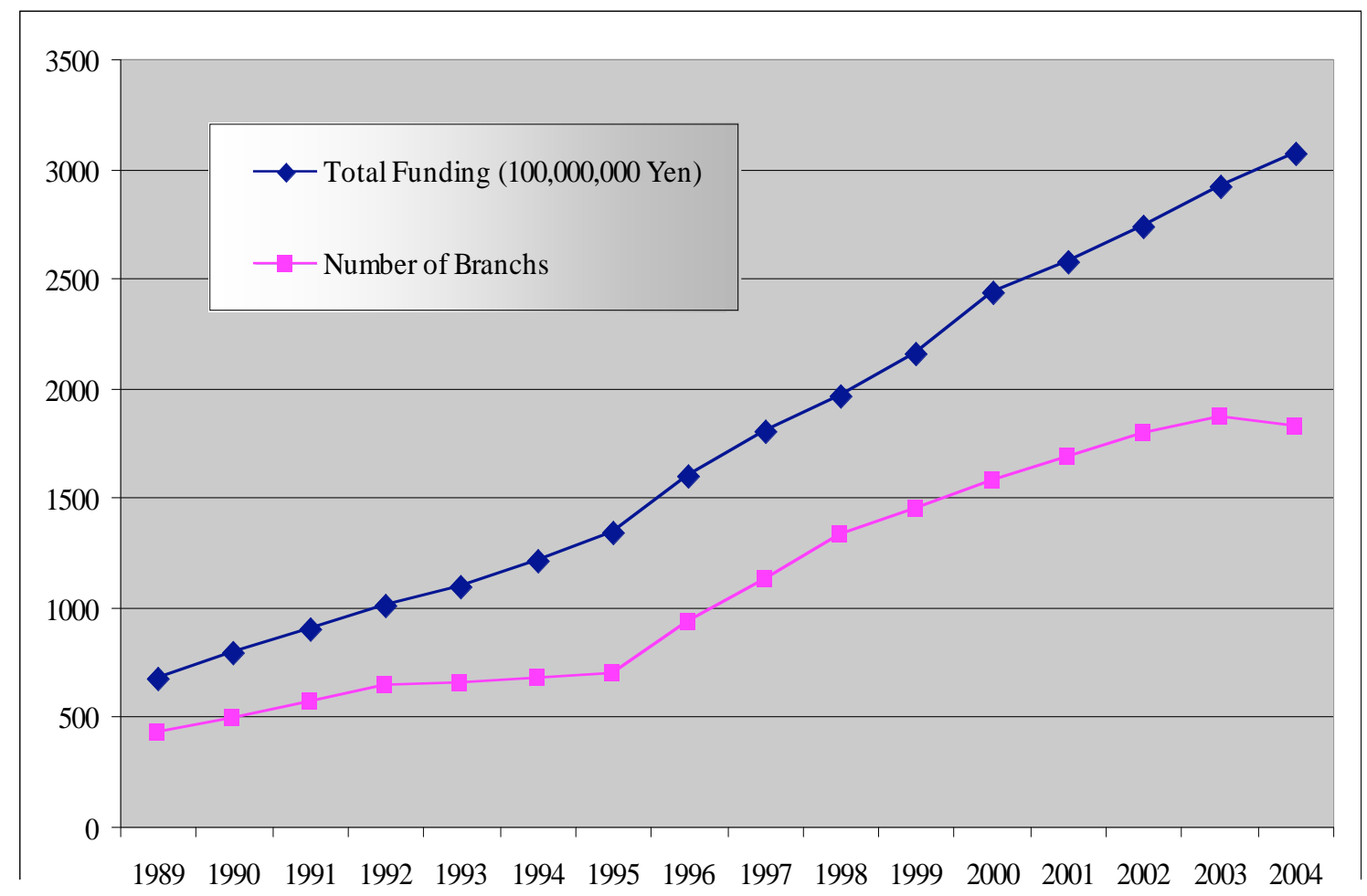

Source: This figure is based on data drawn from National Silver Human Resource Center (2006b) 
Figure 22. Silver Human Resource Center (SHRC, Japan) vs. Senior Employment Program (SCSEP, US), total annual funding of SHRC (FY2004) and of SCSEP (FY2005)

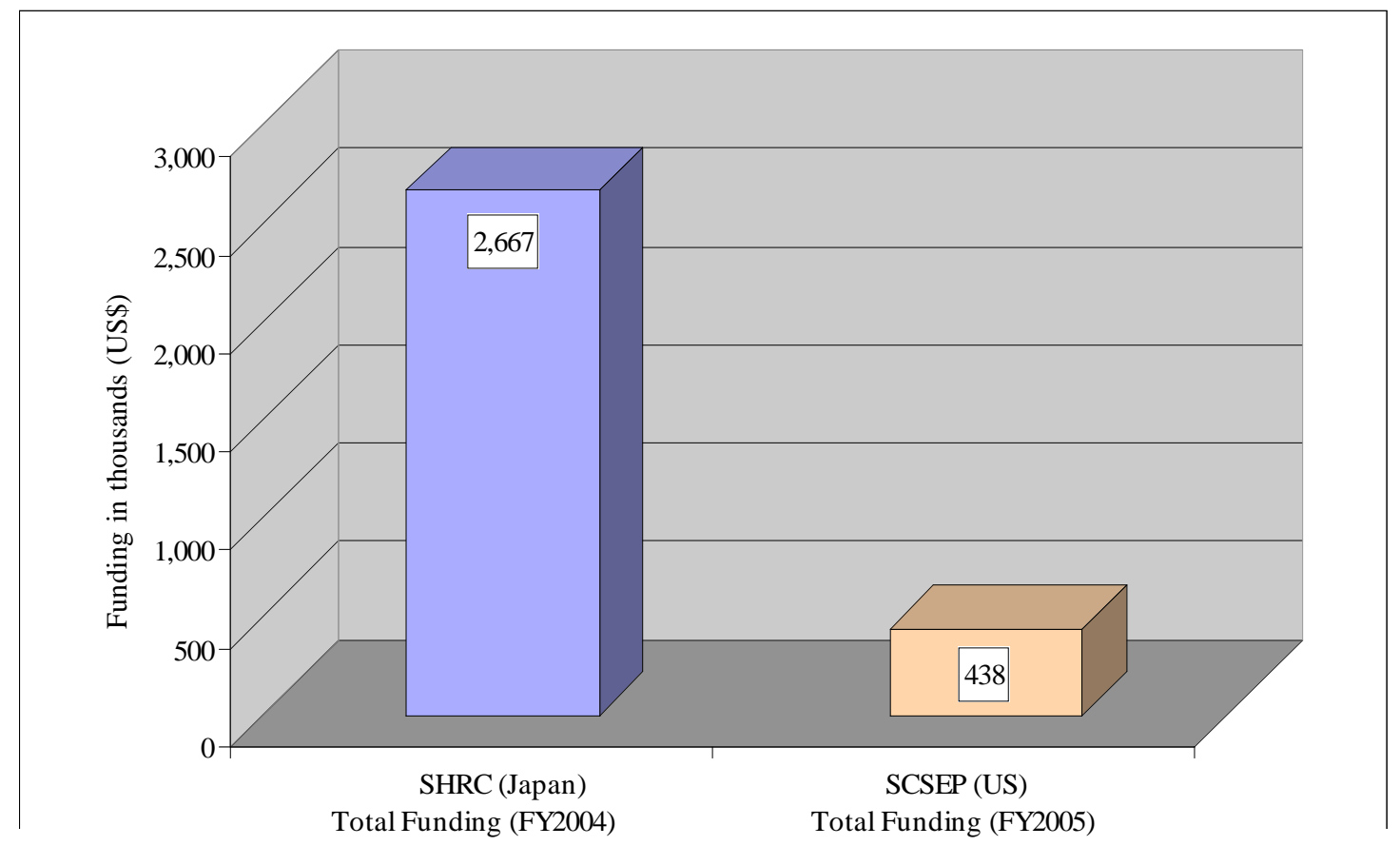

Source: This figure is based on data drawn from National Silver Human Resource Center (2006b) and Senior Community Service Employment Program (2006b). 
Figure 23. Silver Human Resource Center (SHRC, Japan) vs. Senior Employment Program (SCSEP, US), total enrollment as of 2004

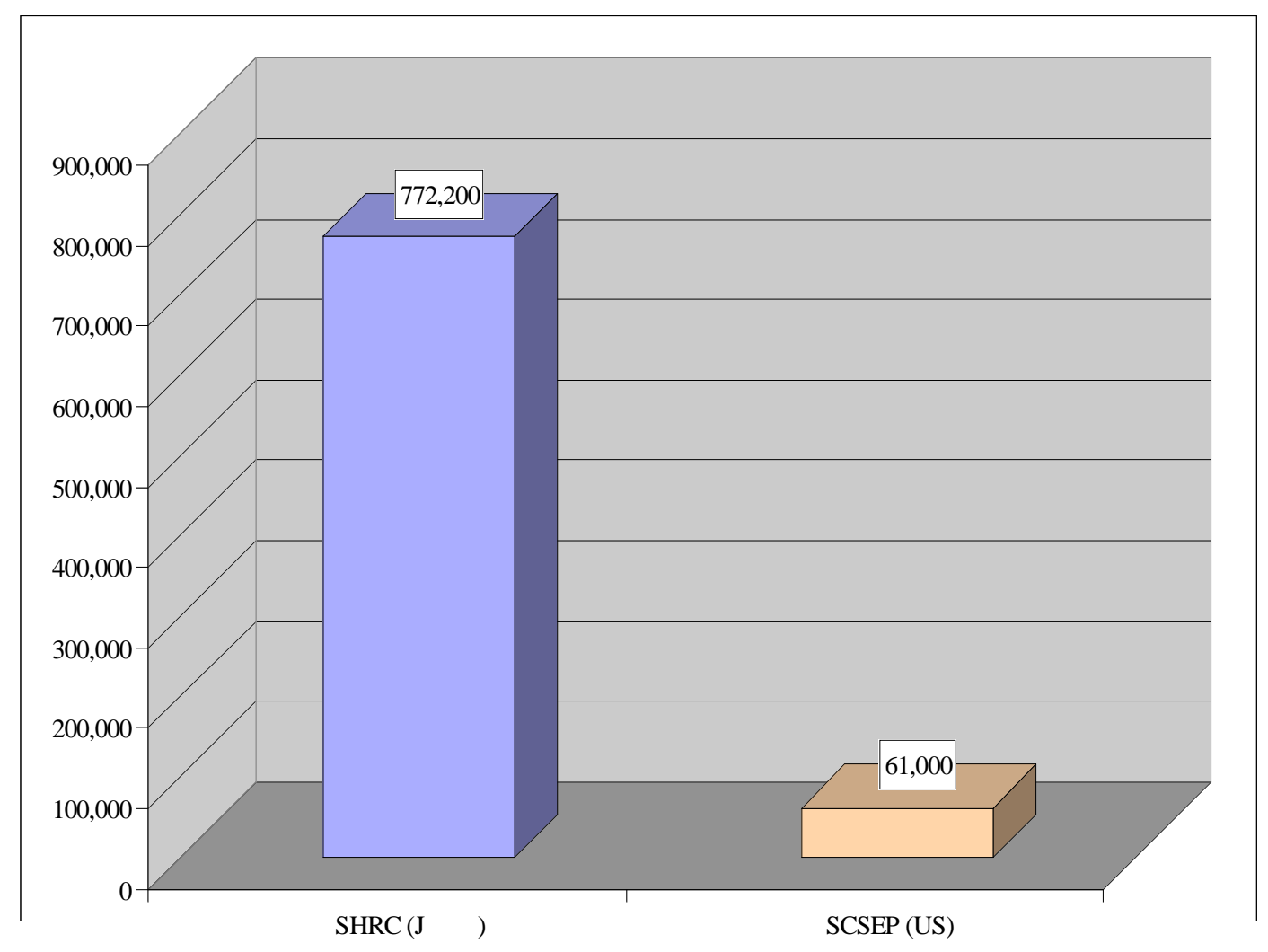

Source: This figure is based on data drawn from the National Silver Human Resource Center (2006b) and the Senior Community Service Employment Program (2006b). 
Figure 24. Silver Human Resource Center (SHRC, Japan) vs. Senior Employment Program (SCSEP, US), share of the enrollment by gender as of 2004

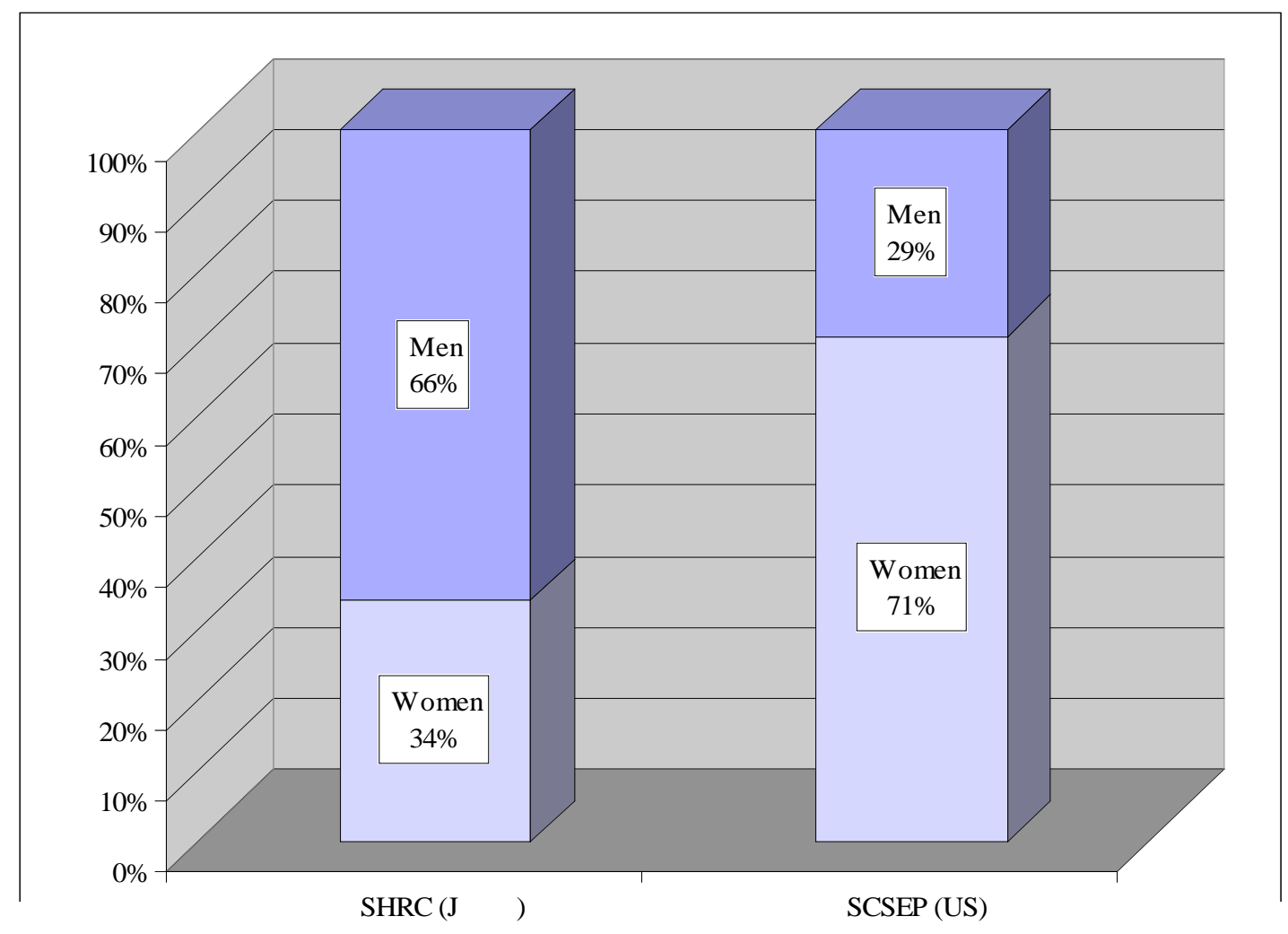

Source: This figure is based on data drawn from the National Silver Human Resource Center (2006b) and the Senior Community Service Employment Program (2006b). 
Figure 25. Industrial countries healthy life expectancy at birth as of 2004

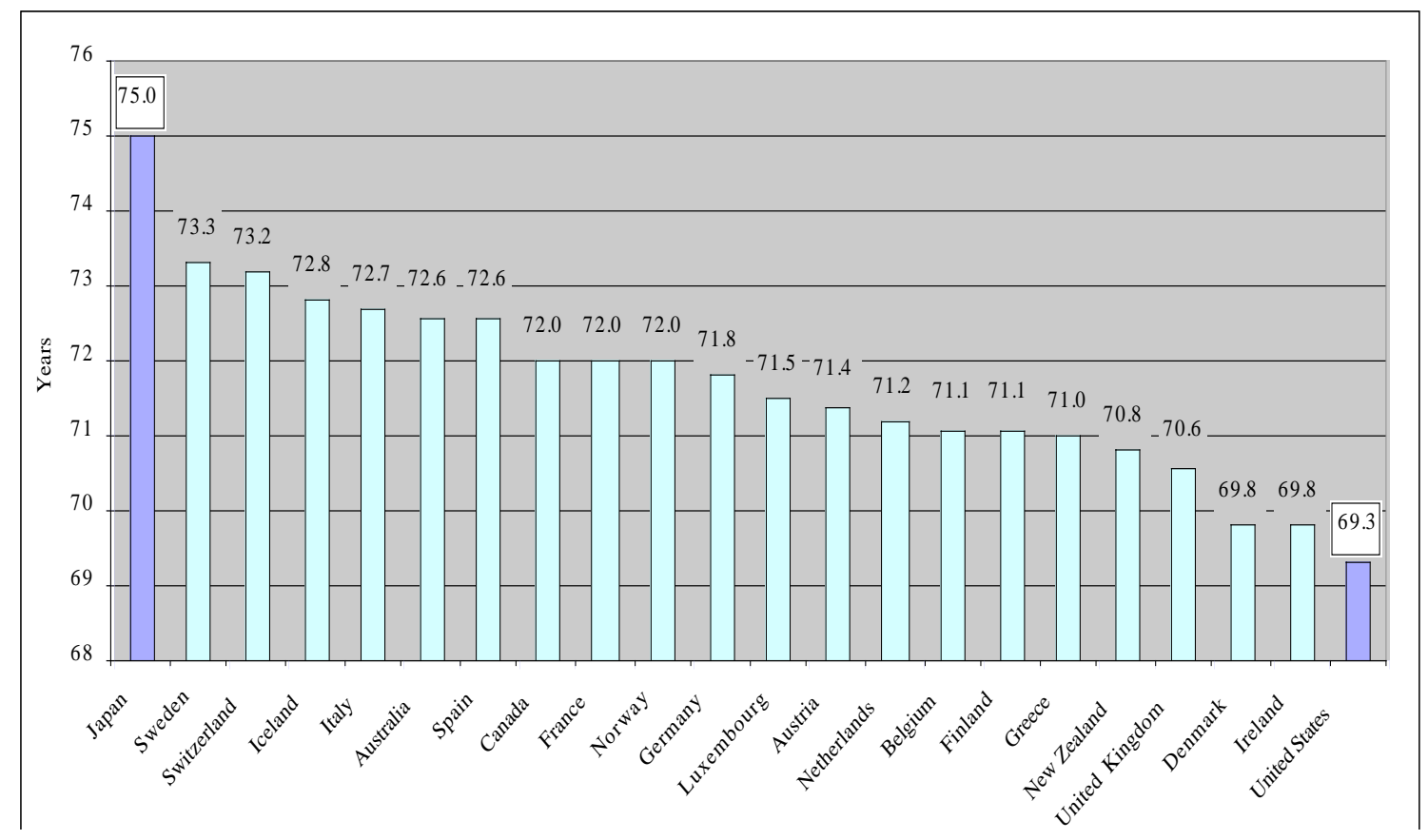

Source: This figure is based on data drawn from WHO (2005). 
Figure 26. U.S. vs. Japan comparison, healthy life expectancy, total population at age 60 as of 2004

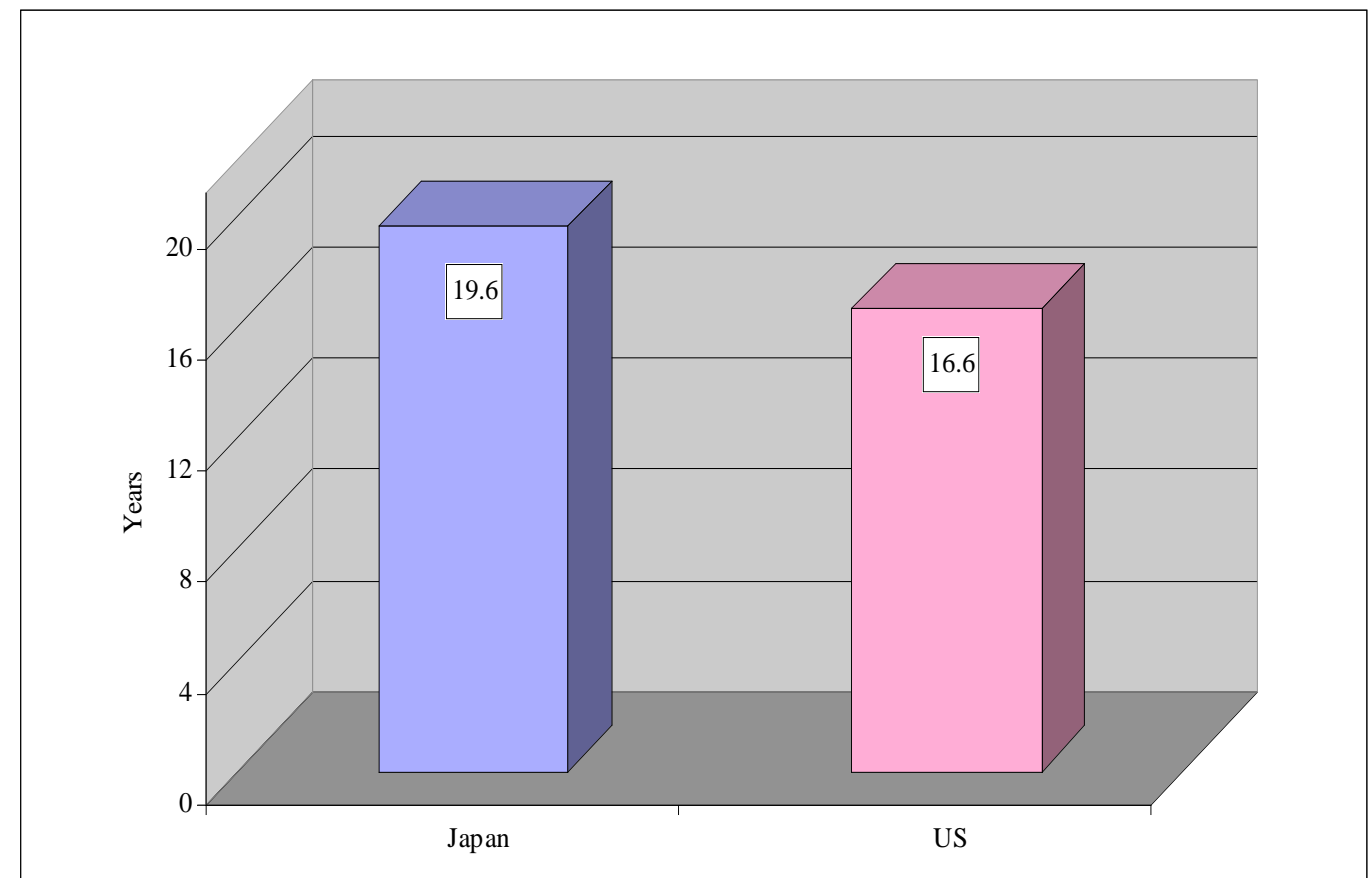

Source: This figure is based on data drawn from WHO (2005). 
Figure 27. U.S. vs. Japan comparison, healthy life expectancy at birth by gender as of 2004

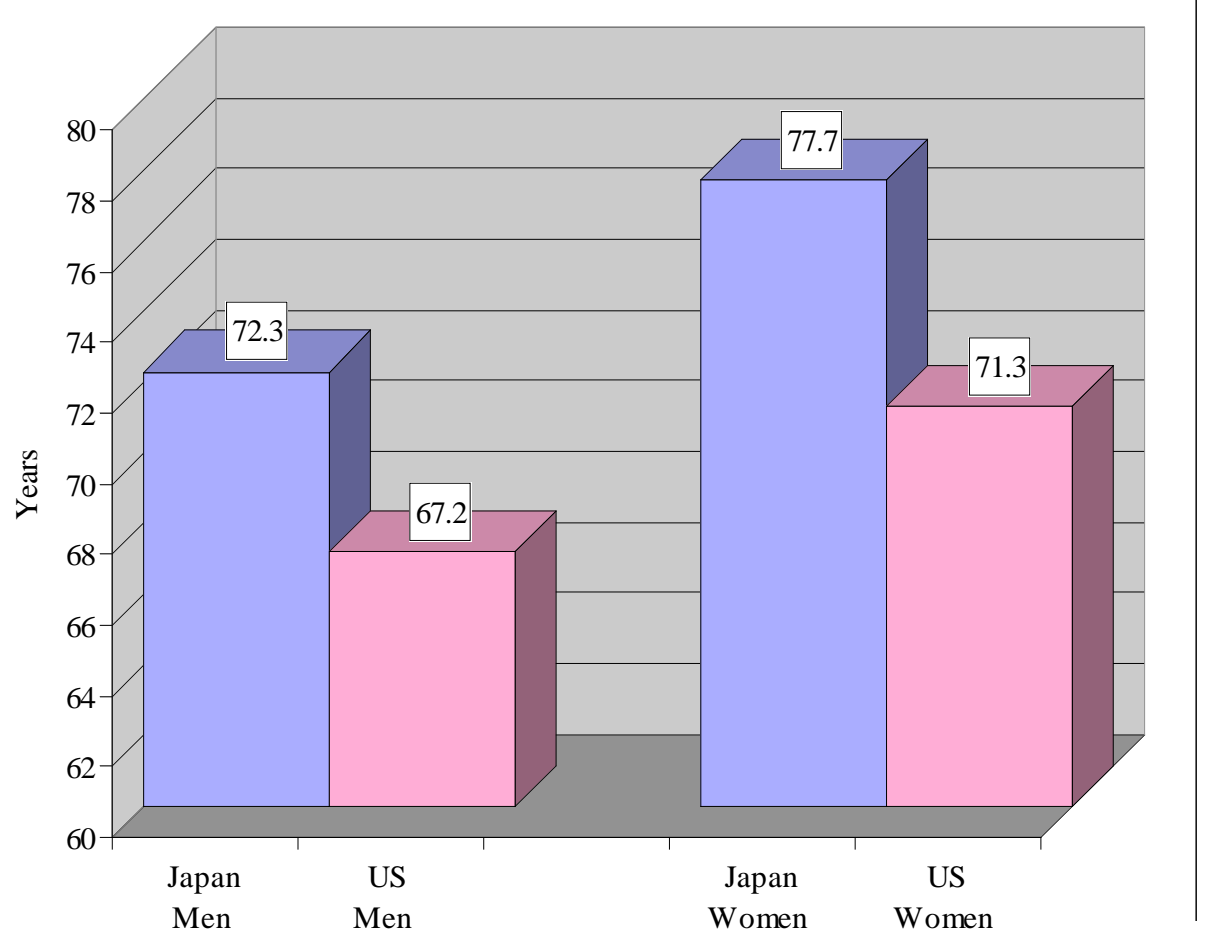

Source: This figure is based on data drawn from WHO (2005). 
Figure 28. U.S. vs. Japan comparison, healthy life expectancy at age 60 (year) by gender as of 2004

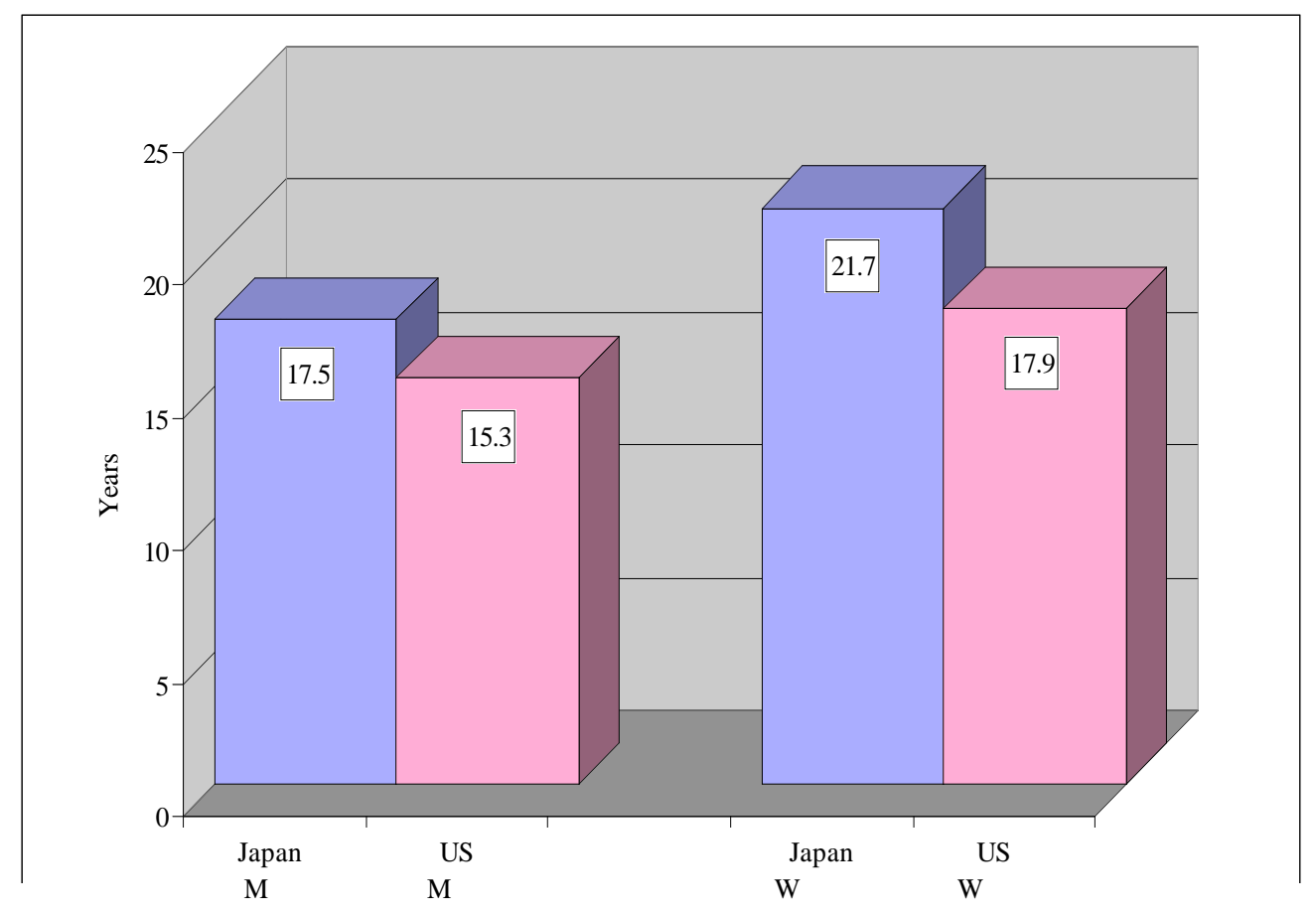

Source: This figure is based on data drawn from WHO (2005). 
Figure 29. U.S. vs. Japan comparison, trends in life expectancy by age

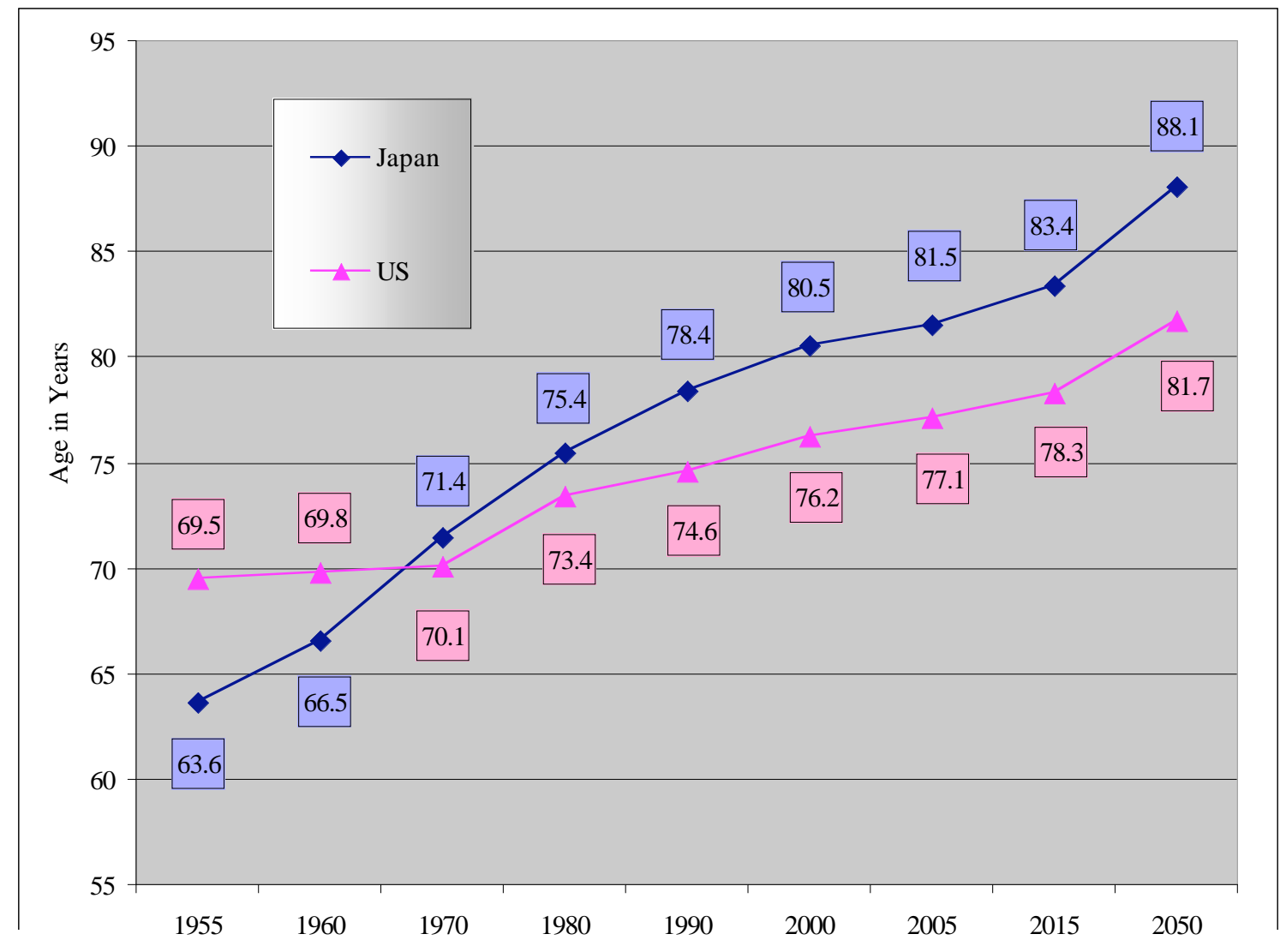

Source: This figure is based on data drawn from WHO (2005) and the Ministry of Health, Labor, and Welfare (2006a). 
Figure 30. U.S. vs. Japan comparison, percent economically active among workers age 60 and over by age group and gender as of 2005

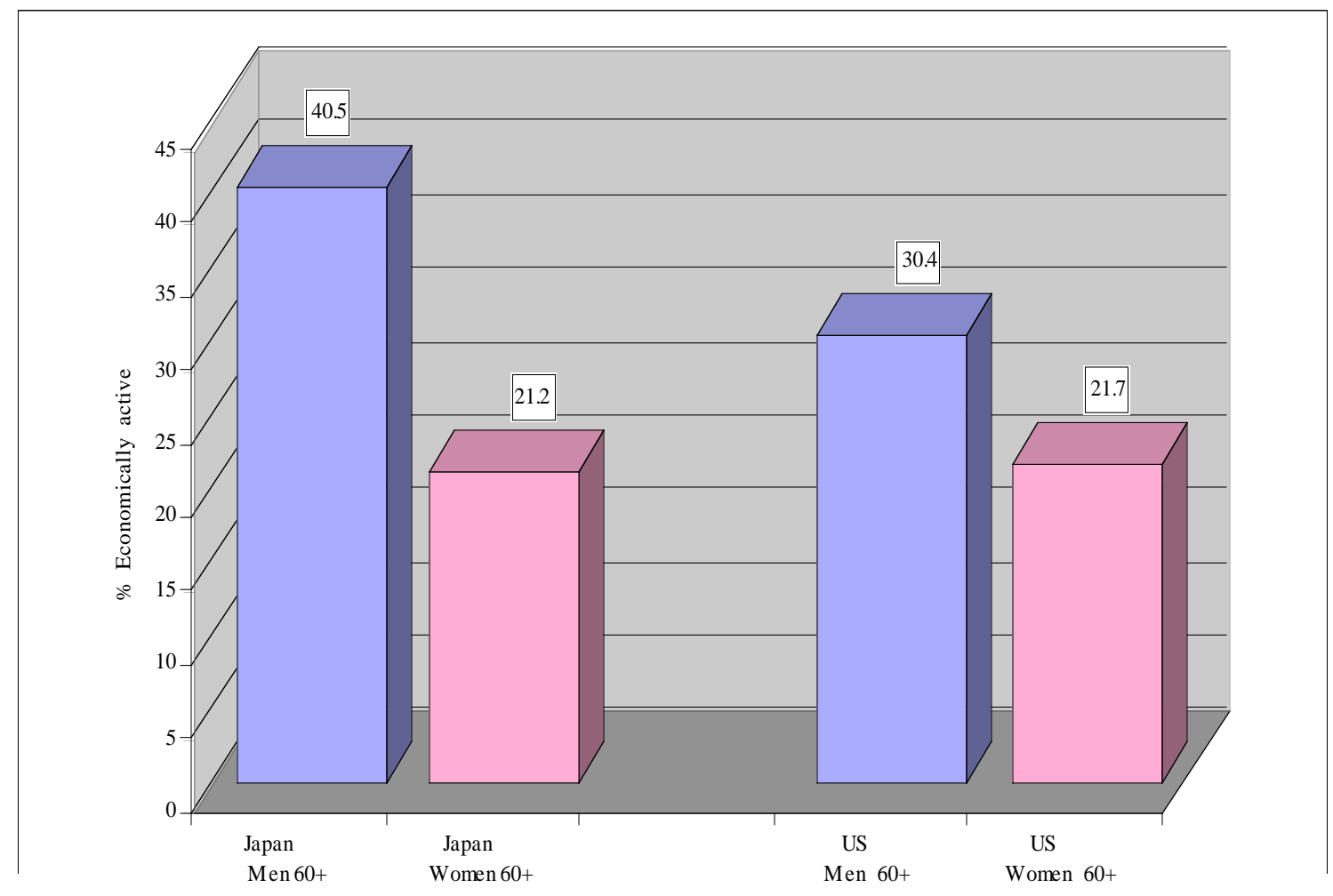

Source: This figure is based on data drawn from ILO (2006). 
Figure 31. U.S. vs. Japan comparison, percent economically active among female older workers by age group as of 2005

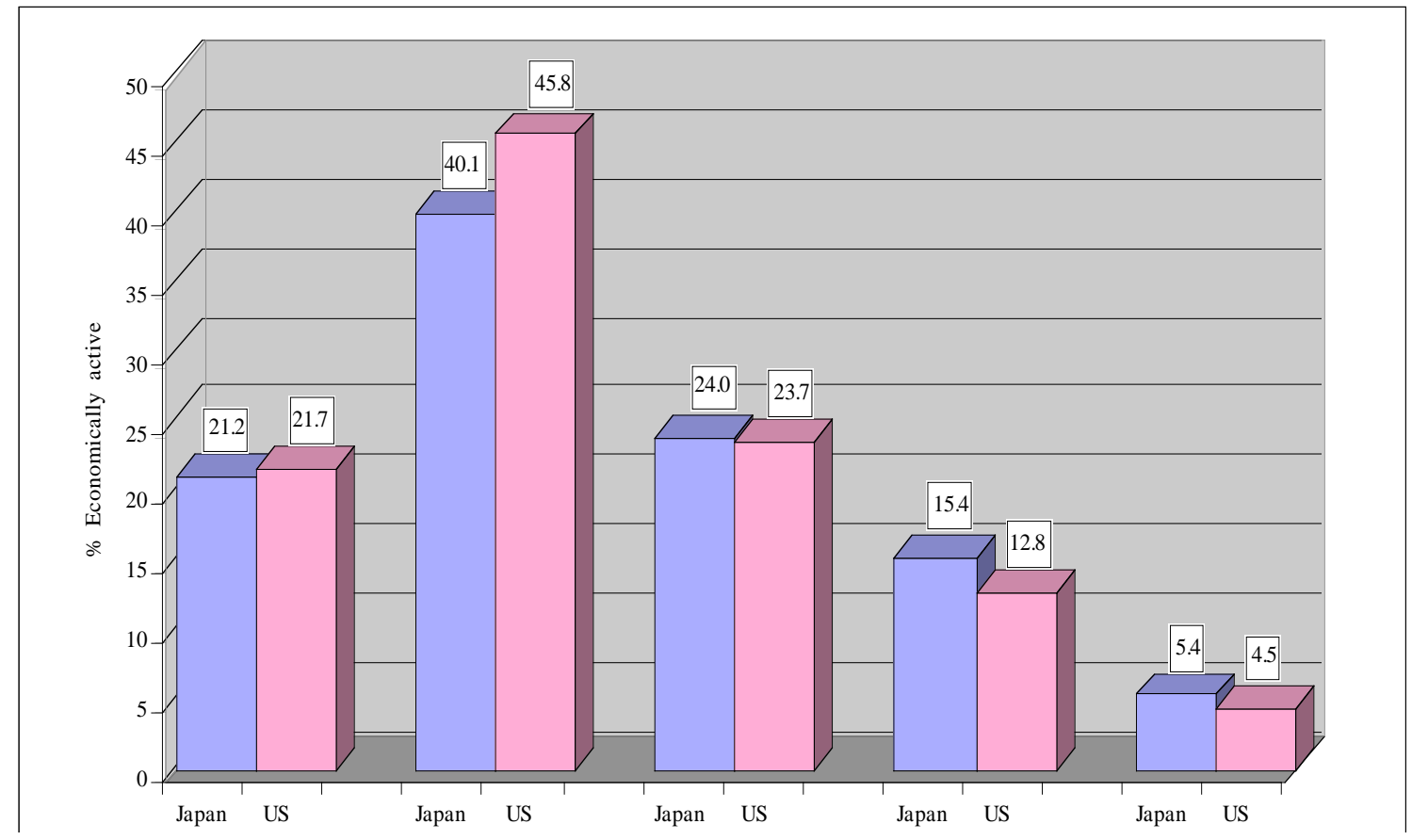

Source: This figure is based on data drawn from ILO (2006). 
Figure 32. Wife vs. husband, "How are you feeling about your (or, your husband's) upcoming retirement?"

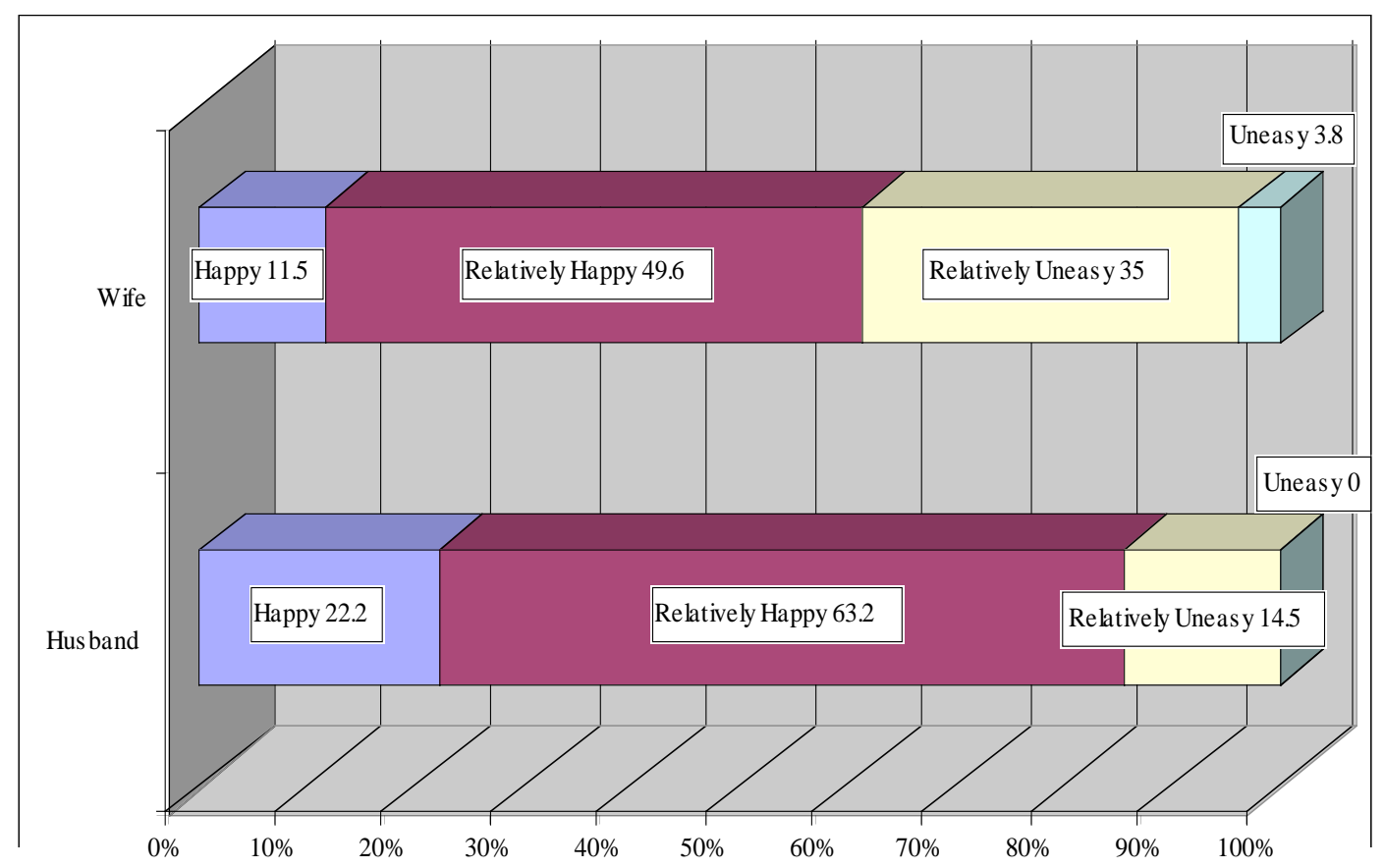

Source: This figure is based on data drawn from Hakuhōdō Elder Business Promotion Office (2005). 
Figure 33. Wife vs. husband, "Which is your (or, your husband's) ideal life style after retirement: 'laid back' or 'active'?”

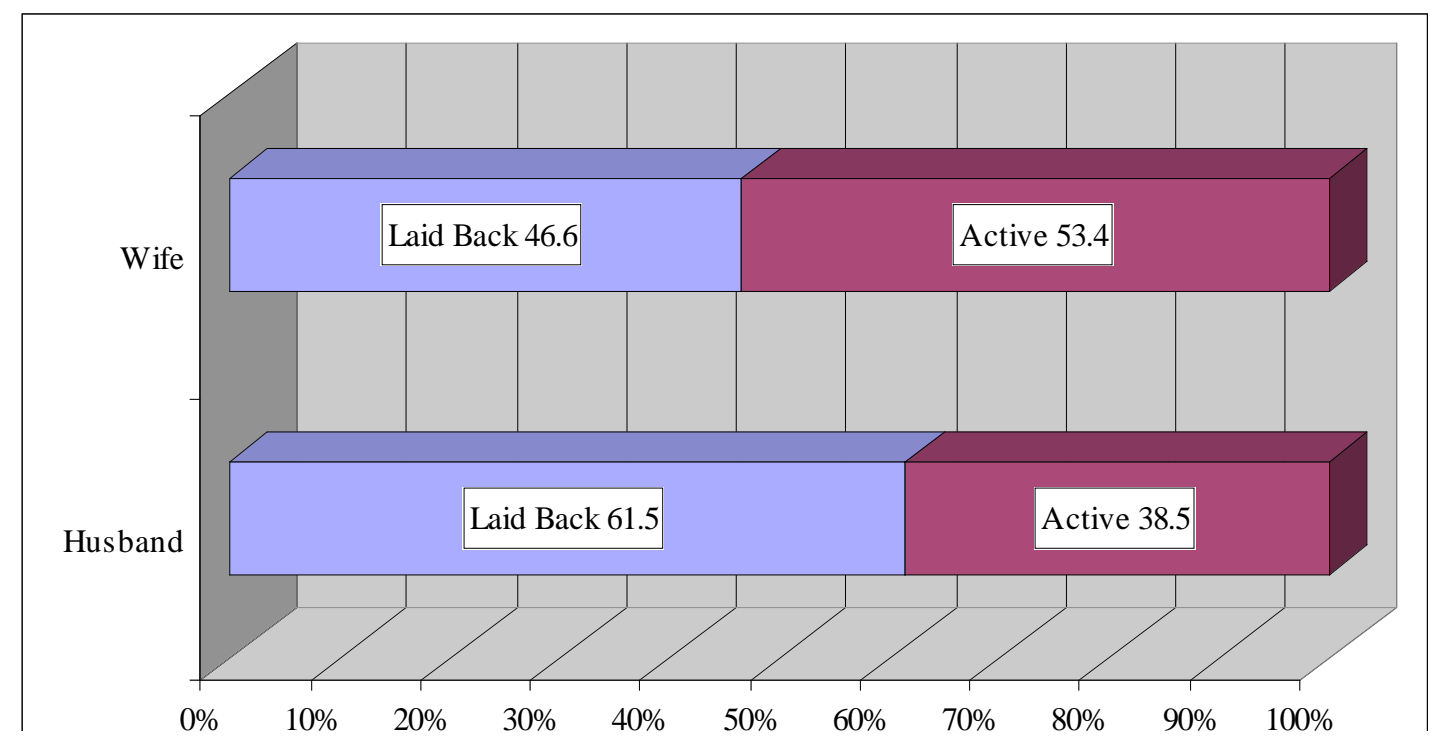

Source: This figure is based on data drawn from Hakuhōdō Elder Business Promotion Office (2005). 
Figure 34. Wife vs. husband, "Would you (or, your husband) like to be socially active or enjoy solitude after retirement?"

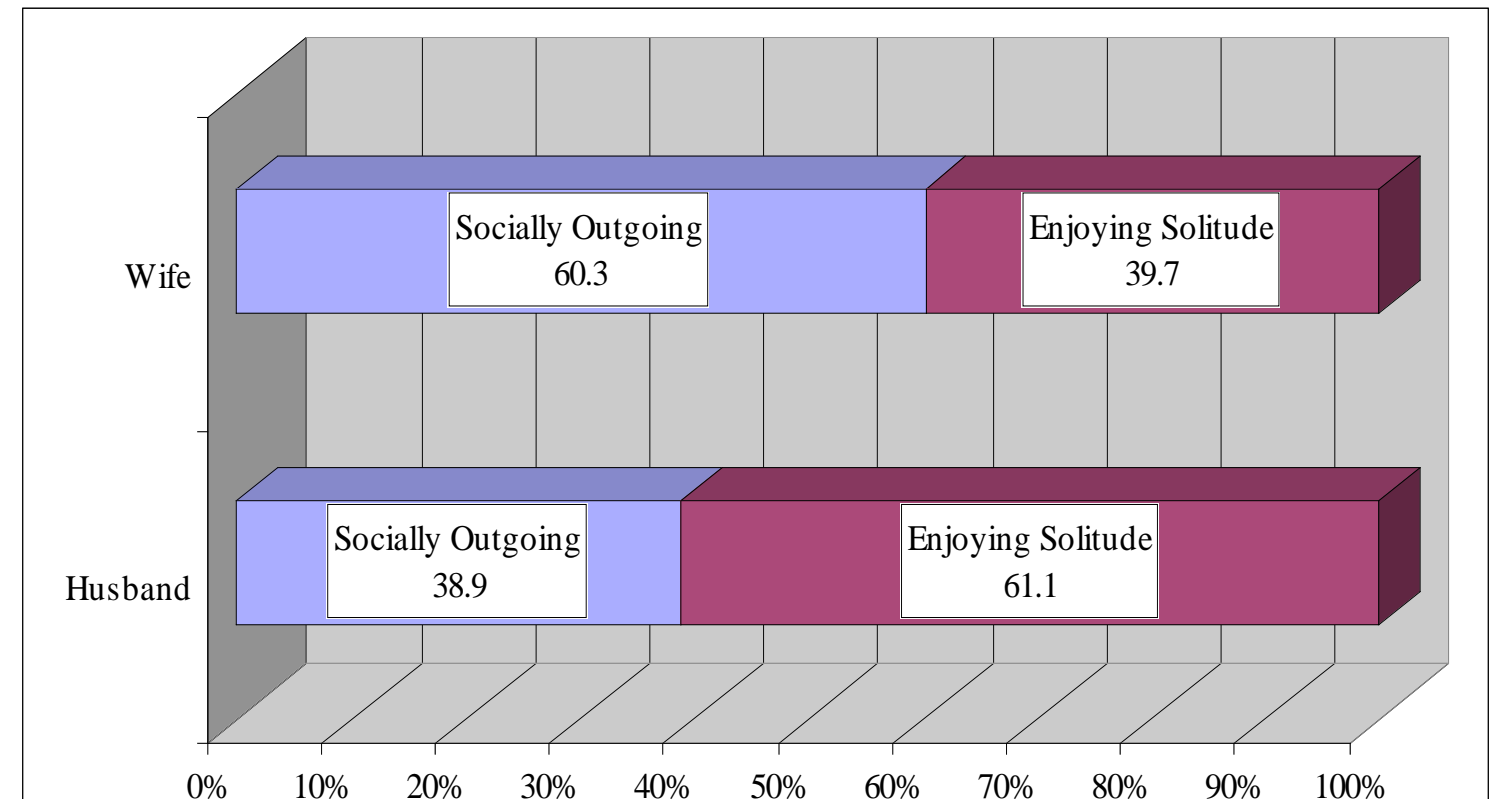

Source: This figure is based on data drawn from Hakuhōdō Elder Business Promotion Office (2005). 
Figure 35. Wife vs. husband, "What is the most desirable way to relate to your spouse as you become older?"

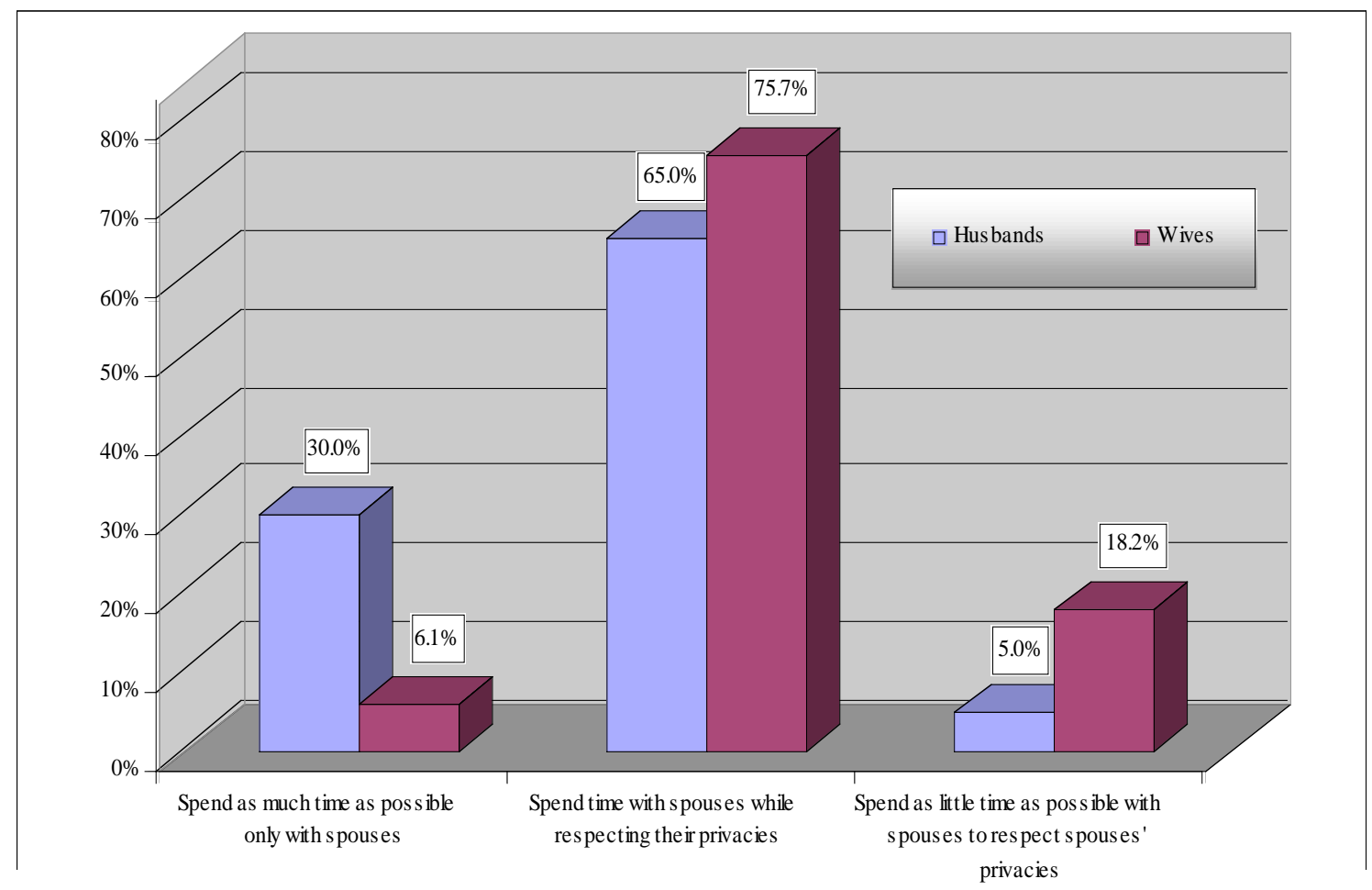

Source: This figure is based on data drawn from the Cabinet Office, Government of Japan (2001). 
Figure 36. Wife vs. husband, "When you become 60 and older, how would you like to spend your leisure time? Choose three answers from the following."

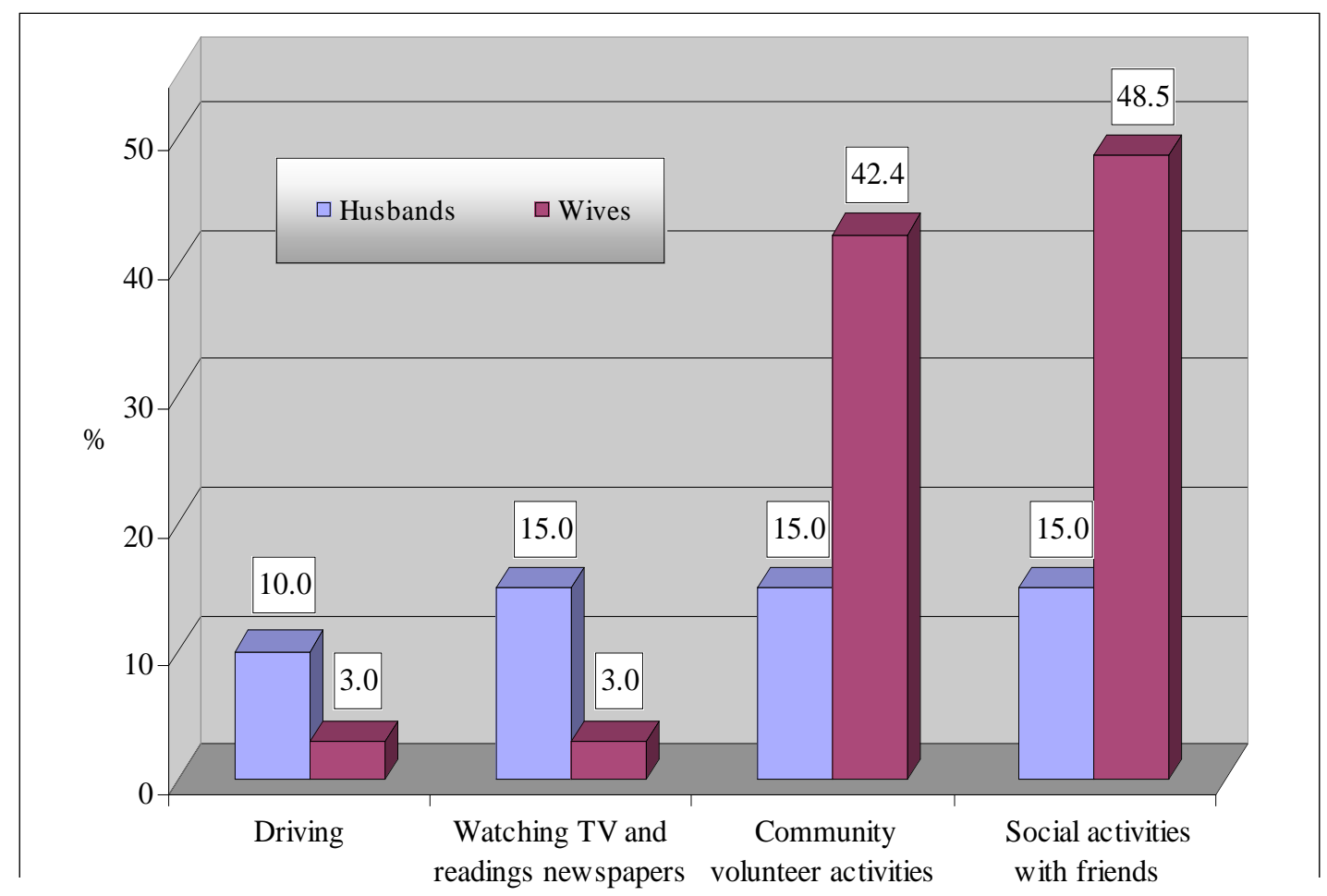

Source: This figure is based on data drawn from the Cabinet Office, Government of Japan (2001). ${ }^{123}$

${ }^{123}$ This survey question provides respondents with eleven choices: 'studying,' 'driving,' 'shopping, eating-out,' 'community volunteer activities,' 'enjoy arts (films, paintings, music, etc.),' 'one-day hiking, picnics,' 'light physical exercise,' 'watching television and reading newspapers,' 'travels,' 'social activities with friends,' and 'hobbies and entertainments.' The survey results do not show significant discrepancies between husbands and wives with any of the choices, except for the four choices shown in the figure above. 
Figure 37. Wife vs. husband, "If your child (or, children) is not available, which of the following would you choose when supports and cares are necessary for you?"

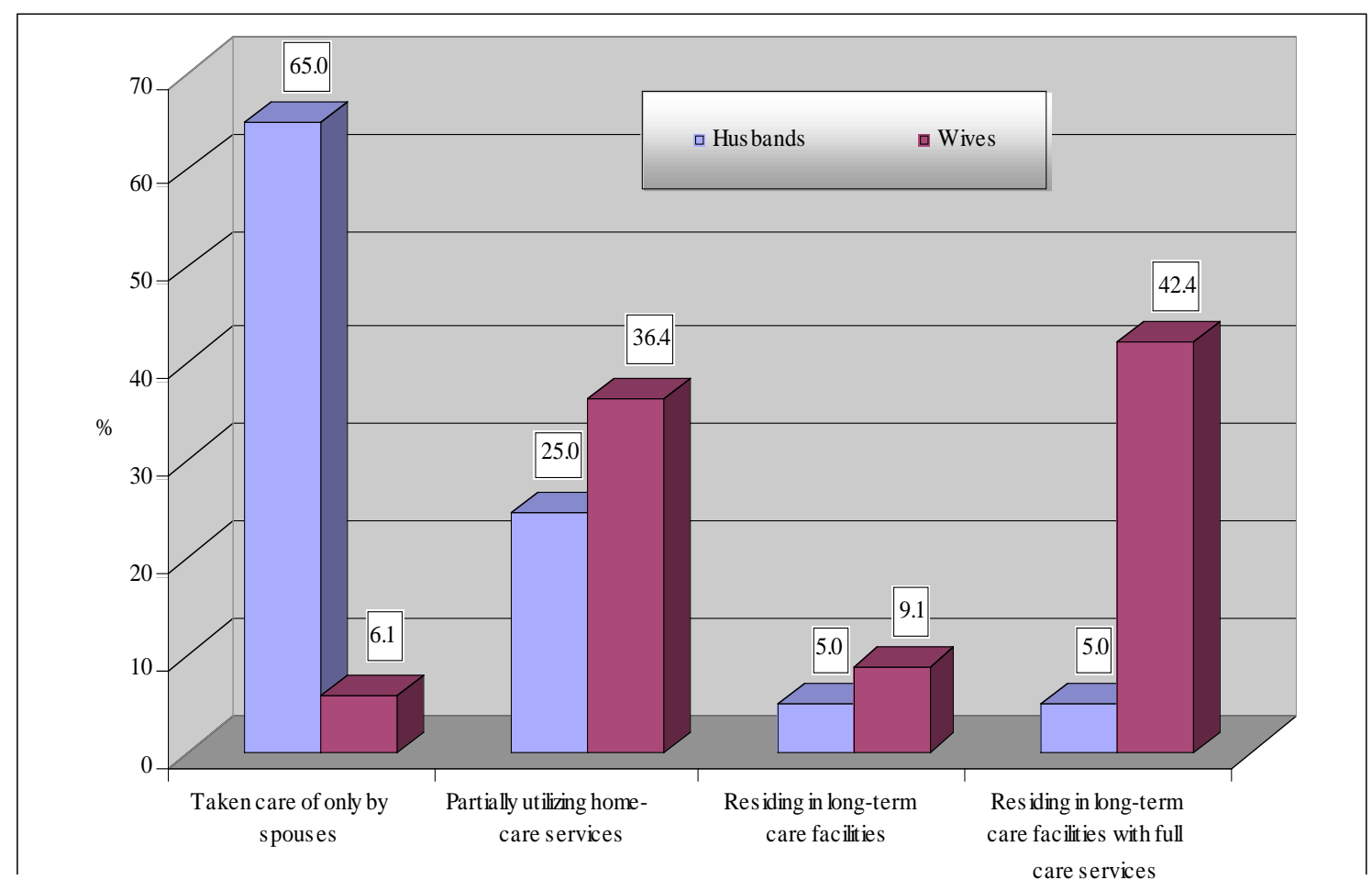

Source: This figure is based on data drawn from the Cabinet Office, Government of Japan (2001). 
Figure 38. Projected labor force participation rate for Japanese workers for the years 2005 through 2020 by age group

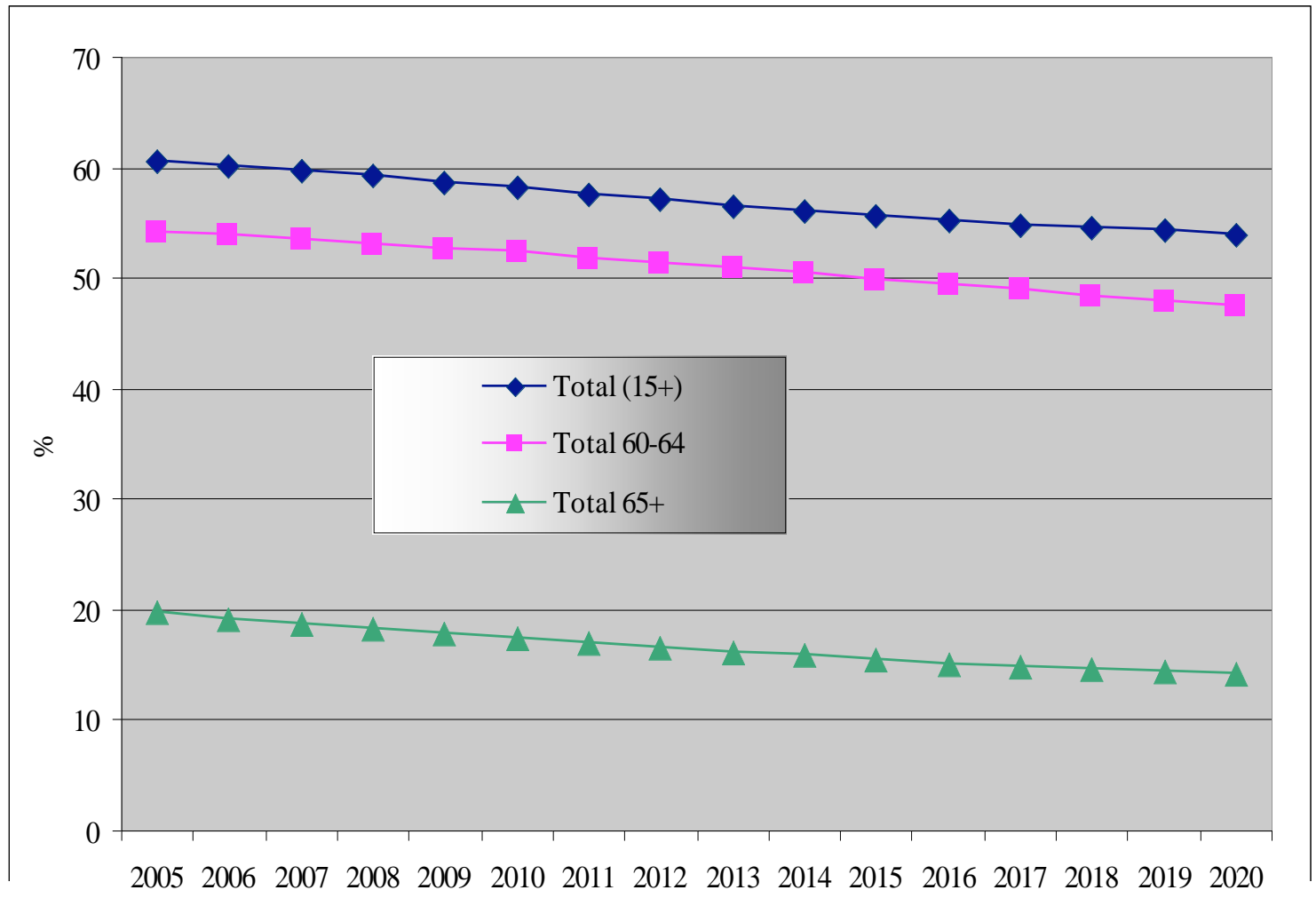

Source: This figure is based on data drawn from the Ministry of Labor, Health, and Welfare (2003). 
Figure 39. Projected labor force participation of men for the years 2005 through 2020 by age group

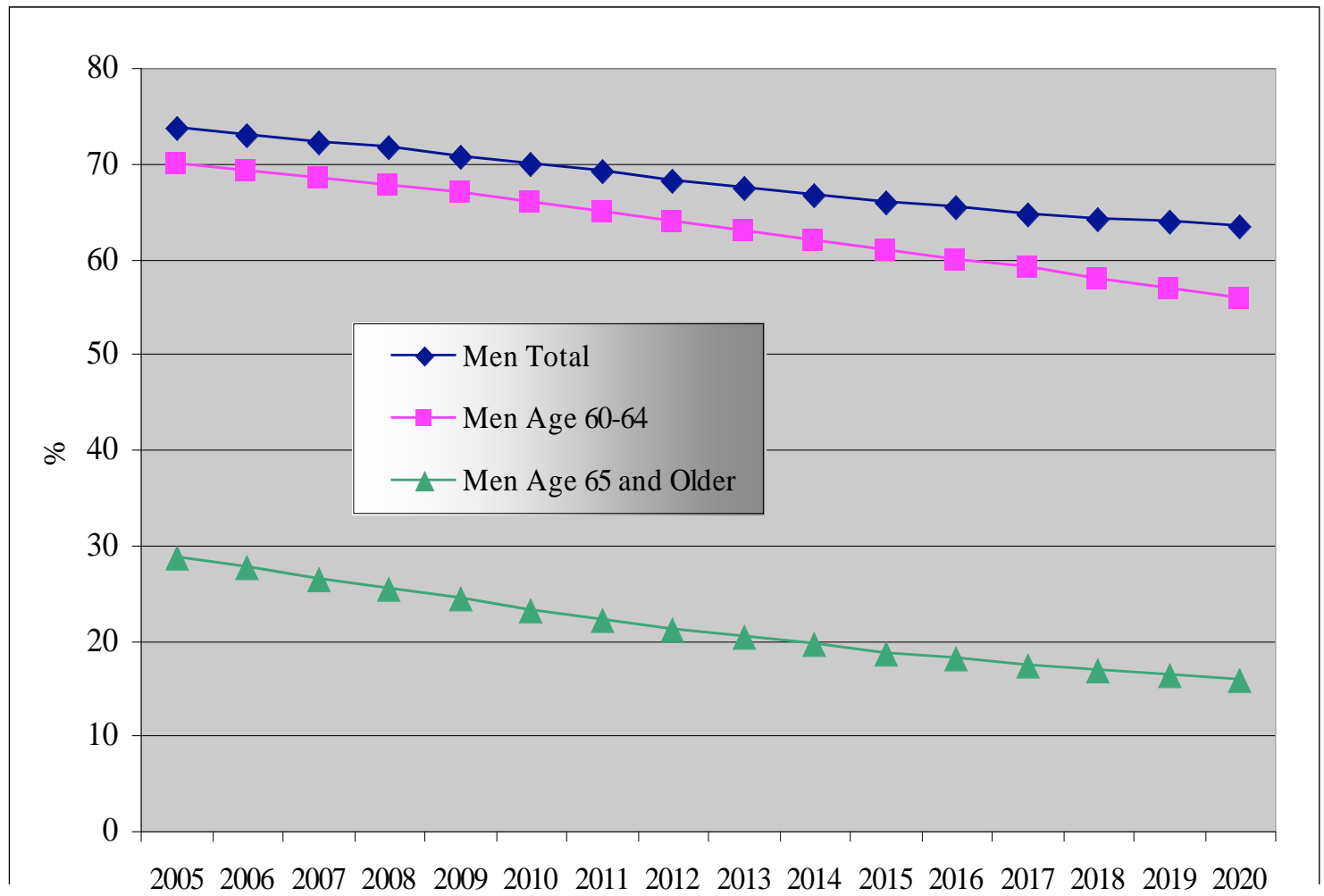

Source: This figure is based on data drawn from the Ministry of Labor, Health, and Welfare (2003). 
Figure 40. Projected labor force participation of women for the years 2005 through 2020 by age group

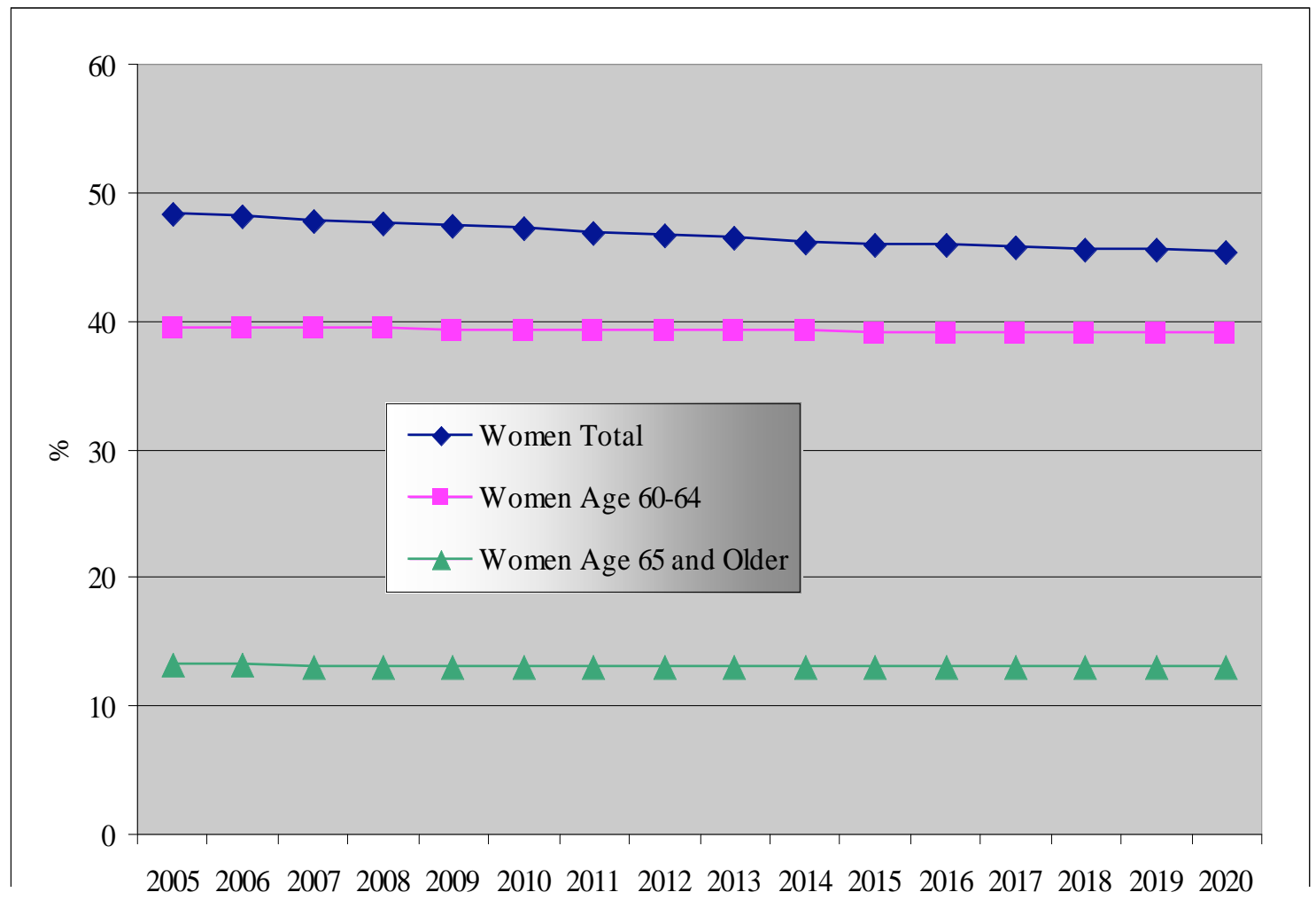

Source: This figure is based on data drawn from the Ministry of Labor, Health, and Welfare (2003). 


\section{RECENT WORKING PAPERS FROM THE}

\section{CENTER FOR RETIREMENT RESEARCH AT BOSTON COLLEGE}

Literacy, Trust and the 401(k) Savings Behavior

Julie R. Agnew, Lisa Szykman, Stephen P. Utkus, and Jean A. Young

The Recent Evolution of Pension Funds in the Netherlands: the Trend to Hybrid DB-DC Plans and Beyond

Eduard H.M. Ponds and Bart van Riel, May 2007

Demographic Influences on Saving-Investment Balances in Developing and Developed Economies

Ralph C. Bryant, May 2007

Social Security Spouse and Survivor Benefits for the Modern Family

Melissa M. Favreault and C. Eugene Steuerle, February 2007

How Economic Security Changes During Retirement

Barbara Butrica, February 2007

International Investment for Retirement Savers: Historical Evidence on Risk and Returns

Gary Burtless, February 2007

Job Changes at Older Ages: Effects on Wages, Benefits, and other Job Attributes Richard W. Johnson and Janette Kawachi, February 2007

Cross-National Comparison of Income and Wealth Status in Retirement: First Results from the Luxembourg Wealth Study (LWS)

Eva Sierminska, Andrea Brandolini and Timothy M. Smeeding, February 2007

Saving and Demographic Change: The Global Dimension

Barry Bosworth and Gabriel Chodorow-Reich, February 2007

The Repeal of the Retirement Earnings Test and the Labor Supply of Older Men Gary V. Engelhardt and Anil Kumar, February 2007

Persistence in Labor Supply and the Response to the Social Security Earnings Test Leora Friedberg and Anthony Webb, December 2006 